$$
\begin{aligned}
& \text { TSP } \\
& \text { UNIVERSIDADE DE SÃO PAULO } \\
& \text { INSTITUTO DE QUÍMICA }
\end{aligned}
$$

\title{
Avaliação de métodos emergentes \\ visando aumentar a eficiência do \\ ozônio na mineralização do azocorante Preto Remazol B
}

\section{Amira Mahmoud}

\section{DISSERTAÇÃO DE MESTRADO}

\author{
Prof. Dr. Renato Sanches Freire \\ Orientador
}

SÃO PAULO

2006 
Aos meus pais, Hussein e Solange, por todo amor a mim dedicado. Aos meus irmãos, Ali, Meiri e Miriam pelo apoio e incentivo. Aos meus amigos, em especial à Thais, por estarem sempre ao meu lado $e$ me apoiarem incondicionalmente... amo todos vocês. 


\section{AGRADECIMENTOS}

Ao Prof. Renato pelo apoio, força, ensinamentos não só acadêmicos, mas para toda a minha vida, pelo carinho recíproco, obrigada pela cobrança e confiança depositados em mim desde o início;

Aos amigos do GPQA, principalmente, Tereza, Perpétua, Thiago, Rafael, Luciana, Lisiane, Giovana e André, que durante meu trabalho muito me ensinaram, apoiaram e incentivaram;

À Dona Fátima pelos cafés de todos os dias;

Aos meus amigos, Thais, Maiara, Jamile, Calol, Maiby, Helen, Karen, Helena, Pé, Lepa, Marina, Eduardo, Marcão e Lolo, pelo o apoio;

Aos Profs. Antônio Carlos Teixeira e José Ermírio Moraes, Audrei e Jeanne do Departamento de Engenharia Química da Escola Politécnica pelas análises de carbono orgânico e todo o suporte necessário no Semi-Industrial;

Ao Prof. Wilfredo Urruchi do Instituto Tecnológico de Aeronáutica pelo o auxílio com o ozonizador e a obtenção de algumas referências;

Aos funcionários do IQ-USP, especialmente, Cibele, Emiliano, Milton e Marcelo da Seção de Pós-graduação pelo o apoio e ao Paulinho (LEM) pela ajuda na confecção da celinha;

À CAPES, FAPESP e ao CNPq pelo auxílio financeiro. 


\section{RESUMO}

Neste trabalho buscaram-se formas de aumentar a eficiência do processo de ozonização sobre a degradação/mineralização de corantes empregados pela indústria têxtil, especificamente do azocorante Preto Remazol B, avaliando o emprego do processo de ozonização catalítica tanto homogênea quanto heterogênea.

O ozônio mostrou uma grande eficiência para promover a degradação dos três tipos de corantes estudados (azo, antraquinona e ftalocianina); permitindo que soluções destes corantes com concentração de $100 \mathrm{mg} \mathrm{L}^{-1}$ sofressem uma total descoloração (destruição do grupo cromóforo) em menos de 2 minutos de ozonização.

Em meio ácido, o ozônio tende a reagir via o mecanismo direto e devido a isto a redução no teor de carbono orgânico total (COT) dos poluentes costuma ser menos eficiente. Em 30 minutos de tratamento o processo $\mathrm{O}_{3} / \mathrm{pH} 3$ permitiu somente $30 \%$ de mineralização do azocorante estudado. Por outro lado, o $\mathrm{O}_{3}$ pode ter sua decomposição catalisada por vários materiais, levando à formação de espécies radicalares, principalmente o radical hidroxila ( $\mathrm{HO}$ ). Devido ao caráter não seletivo dos radicais hidroxila, o mecanismo de ozonização indireto costuma ser mais eficiente na oxidação de compostos orgânicos. Um exemplo clássico deste mecanismo é o processo $\mathrm{O}_{3} / \mathrm{pH} 11$, que mineralizou $56 \%$ do COT do azocorante após 30 minutos de ozonização.

Uma estratégia para promover uma melhora na mineralização do corante Preto Remazol B pelo processo de ozonização em meio ácido foi a adição de peróxido de hidrogênio ao meio reacional. $\mathrm{O}$ tratamento $\mathrm{O}_{3} / \mathrm{pH} 3 / \mathrm{H}_{2} \mathrm{O}_{2}$ permitiu um aumento de $51 \%$ na mineralização do azocorante após 30 minutos de ozonização. $\mathrm{O}$ aumento da eficiência do ozônio também foi avaliado empregando-se o processo de ozonização na presença de metais $\left(\mathrm{Mn}^{2+} \mathrm{e} \mathrm{Fe}^{3+}\right)$. Em 30 minutos de tratamento, o processo $\mathrm{O}_{3} / \mathrm{pH} 3 / \mathrm{Mn}^{2+}$ mineralizou 67, 78 e $57 \%$ do COT dos corantes Preto Remazol B, Azul Brilhante RN e Turquesa Remazol G, respectivamente. No mesmo tempo de tratamento $\mathrm{O}_{3} / \mathrm{pH} 3 / \mathrm{Fe}^{3+}$ permitiu uma remoção de COT de 57, 64 e 41\% para Preto Remazol B, Azul Brilhante RN e Turquesa Remazol G, respectivamente.

A presença dos metais estudados na forma sólida $\left(\mathrm{MnO}_{2}\right)$ ou em suportes $\left(\mathrm{SiO}_{2} / \mathrm{MnO}_{2}\right.$ e $\left.\mathrm{SiO}_{2} / \mathrm{Fe}_{2} \mathrm{O}_{3}\right)$, além de permitir uma remoção de até $79 \%$ do COT do azocorante em 30 minutos de tratamento, também mostra uma alternativa para viabilizar o emprego dos agentes catalisadores da decomposição do ozônio, uma vez que na forma suportada os mesmos podem ser utilizados de forma contínua, minimizando etapas de recuperação ou perdas destes materiais. 


\section{ABSTRACT}

The main goal of this study was to find means to increase the efficiency of ozonation process over the degradation/mineralization of dyes used in the textile industry, mainly the azodye Remazol Black B, evaluating the use of either homogeneous or heterogeneous catalytic ozonation methods.

Ozone showed great efficiency to promote the degradation of the three types of studied dyes (azo, anthraquinone and phtalocyanine) enabling the discoloration (destruction of chromophore group) of solutions with $100 \mathrm{mg}_{\mathrm{dye}} \mathrm{L}^{-1}$ in less than 2 minutes.

In acidic medium, ozone tends to react via the direct mechanism. In this way, the reduction of total organic carbon (TOC) of the polluents uses to be less efficient. In 30 minutes of treatment, the process $\mathrm{O}_{3} / \mathrm{pH} 3$ allowed only $30 \%$ of mineralization of the studied azodye. On the other hand, $\mathrm{O}_{3}$ can be decomposed by several materials, leading to the formation of radical species, mainly the hydroxyl radical (HO). Due to the nonselective character of hydroxyl radicals, the indirect mechanism of ozonation usually is more efficient in the oxidation of organic compounds. A classic example of this mechanism is the process $\mathrm{O}_{3} / \mathrm{pH} 11$ that mineralized $56 \%$ of TOC of the azodye after 30 minutes of ozonation.

Another strategy to promote an improvement in the mineralization of the azodye Remazol Black B using the ozonation process in acid medium was the addition of hydrogen peroxide to the reactional medium. The treatment $\mathrm{O}_{3} / \mathrm{pH} 3 / \mathrm{H}_{2} \mathrm{O}_{2}$ enabled an increase of $51 \%$ in the mineralization of the azodye after 30 minutes. The increase in the efficiency of ozone was also evaluated using the ozonation process in the presence of metallic ions $\left(\mathrm{Mn}^{2+}\right.$ and $\left.\mathrm{Fe}^{3+}\right)$. In 30 minutes of treatment, the process $\mathrm{O}_{3} / \mathrm{pH} 3 / \mathrm{Mn}^{2+}$ mineralized 67,78 and $57 \%$ of the TOC of the dyes Remazol Black B, Blue Brilliant RN and Remazol Turquoise G133, respectively. In the same time of treatment, the process $\mathrm{O}_{3} / \mathrm{pH}_{3} / \mathrm{Fe}^{3+}$ mineralized 57,64 and $41 \%$ of the TOC of he dyes Remazol Black B, Blue Brilliant RN and Remazol Turquoise G133, respectively.

The presence of the studied metals in the solid form $\left(\mathrm{MnO}_{2}\right)$ or on supports $\left(\mathrm{SiO}_{2} / \mathrm{MnO}_{2}\right.$ e $\left.\mathrm{SiO}_{2} / \mathrm{Fe}_{2} \mathrm{O}_{3}\right)$, enabled the removal of up to $79 \%$ of the TOC of the azo in 30 minutes of ozonation. Moreover, these methods showed an alternative to permit the use of catalytic agents to decompose ozone, as in the supported form, they can be used in a continuous form, minimizing steps of recuperation or loss of these materials. 


\section{ÍNDICE GERAL}

ÍNDICE DE FIGURAS

ÍNDICE DE TABELAS xiv

1. INTRODUÇÃO

1.1. Problemática da água 1

1.2. Indústria têxtil e processos de tratamento 3

1.3. Ozônio 6

1.4. Ozonização catalítica homogênea 16

1.5. Ozonização catalítica heterogênea 21

2. OBJETIVOS 26

2.1. Objetivos específicos 26

3. PARTE EXPERIMENTAL 27

3.1. Reagentes 27

3.2. Controle analítico 30

3.2.1.Determinação da degradação dos grupos cromóforos 30 (descoloração)

3.2.2. Determinação da mineralização 31

3.2.3. Determinação do $\mathrm{pH} \quad 31$

3.2.4. Determinação de demanda química de oxigênio (DQO) 32

3.3. Método lodométrico para o cálculo da constante de 32 transferência de massa

3.4. Cinética da degradação 33

3.5. Síntese do material suporte para o processo de ozonização 33 catalítica heterogênea

3.5.1. Sílica Mesoporosa Ordenada (SMO) 34

3.5.2. $\mathrm{SMO}-\mathrm{Fe}_{2} \mathrm{O}_{3}$

3.5.3. $\mathrm{SMO}-\mathrm{MnO}_{2} \quad 34$

3.5.3.1. Incorporação 35

3.5.3.2. Modificação superficial $\quad 35$ 
4. RESULTADOS E DISCUSSÕES 36

4.1. Sistema de ozonização 36

4.1.1. Produção de ozônio 36

4.1.2. Transferência de massa no reator 40

4.1.3. Monitoramento da produção de ozônio 43

4.2. Estudo da degradação e mineralização de corantes por 46 diferentes processos de ozonização

4.2.1. Ozonização do corante modelo Preto Remazol B 47

4.2.1.1. Degradação do corante 47

4.2.1.2. Influência do $\mathrm{pH}$ no processo de ozonização 51

4.2.1.3. Influência da adição de peróxido de hidrogênio 58

4.2.1.4. Influência da adição de metais em solução no processo 61 de ozonização

4.2.1.4.1. Processo $\mathrm{O}_{3} / \mathrm{pH}_{3} / \mathrm{Mn}^{2+} \quad 61$

4.2.1.4.2. Processo $\mathrm{O}_{3} / \mathrm{pH}_{3} / \mathrm{MnO}_{2} \quad 64$

4.2.1.4.3. Efeito sinérgico da adição simultânea de íons 66 manganês (II) e peróxido de hidrogênio em solução durante o processo de ozonização

4.2.1.4.4. Processo $\mathrm{O}_{3} / \mathrm{pH}_{3} / \mathrm{Fe}^{3+} \quad 70$

4.2.1.4.5. Análise comparativa dos diferentes processos 74

4.2.2. Ozonização dos corantes Azul Remazol Brilhante RN e 75 Turquesa Remazol G 133

4.2.2.1. Degradação dos corantes 75

4.2.2.2. Mineralização dos corantes 76

4.3. Ozonização de um efluente têxtil $\quad 79$

4.4. Metais suportados em SMO $\quad 80$

4.4.1. $\mathrm{O}_{3} / \mathrm{pH} / \mathrm{SMO}-\mathrm{Fe}_{2} \mathrm{O}_{3} \quad 80$

4.4.2. $\mathrm{O}_{3} / \mathrm{pH} / \mathrm{SMO}-\mathrm{MnO}_{2}$

5. CONCLUSÃO 85

5.1. PERSPECTIVAS 86

6. REFERÊNCIAS 
$\begin{array}{ll}\text { 7. CURRICULUM VITAE } & 93\end{array}$

7.1. Histórico Educacional 93

$\begin{array}{ll}\text { 7.2. Cursos } & 93\end{array}$

7.3. Publicação em Revista Científica 93

7.4. Participação em Congresso 93 


\section{ÍNDICE DE FIGURAS}

Figura 1. Representação esquemática de uma estação de tratamento

de efluentes por lodos ativados, tipicamente empregados para o tratamento de efluentes têxteis.

Figura 2. Reação direta do ozônio com a matéria orgânica: mecanismo de Criegee (A). Exemplo de um ataque eletrofílico do ozônio a um composto aromático (B).

Figura 3. Mecanismos de reação direto e indireto do ozônio com a matéria orgânica em meio aquoso $\left(\mathrm{MO}=\right.$ matéria orgânica; $\mathrm{MO}_{\mathrm{ox}}=$ matéria orgânica oxidada).

Figura 4. Diferentes formas de interação do ozônio com a matéria orgânica adsorvida na superfície do metal, formação de $\mathrm{O}_{2}$ (a) e formação de $\mathrm{O} \cdot(\mathrm{b})$.

Figura 5. Estruturas químicas dos corantes utilizados neste estudo.

Figura 6. Sistema de geração de ozônio.

Figura 7. Esquema simplificado do princípio de funcionamento do 36 sistema de geração de ozônio baseado no método de descarga por efeito corona.

Figura 8. Perfil da produção de ozônio em função da diferença de potencial aplicada. Vazão de oxigênio: $30 \mathrm{~L} \mathrm{~h}^{-1}$.

Figura 9. Produção de ozônio em função da diferença de potencial aplicada. Vazão de oxigênio: $30 \mathrm{~L} \mathrm{~h}^{-1}$.

Figura 10. Concentração de ozônio (a) e quantidade de ozônio produzido (b) em diferentes vazões de entrada de $\mathrm{O}_{2}$. Potencial aplicado para a geração de ozônio: 5 kV.

Figura 11. Esquema da interface gás-líquido. 
Figura 12. Variação da concentração de ozônio no meio aquoso em função do tempo. Potencial aplicado para a geração de ozônio: 5 kV.

Figura 13. Variação da absorção de radiação UV $(\lambda=258 \mathrm{~nm})$ pelo 45 ozônio gasoso durante um processo de ozonização. Vazão de $\mathrm{O}_{2}=$ $54 \mathrm{~L} \mathrm{~h}^{-1}$.

Figura 14. Espectro UV/Vis de uma solução do corante Preto Remazol 48 $B$ após diferentes tempos de tratamento por ozonização. Condições experimentais: $\mathrm{pH}=3$; [corante $]_{0}=100 \mathrm{mg} \mathrm{L}^{-1}$; vazão de $\mathrm{O}_{2}=54 \mathrm{~L} \mathrm{~h}^{-1}$.

Figura 15. Variação da concentração de carbono orgânico total em função do tempo de ozonização de uma solução do corante Preto Remazol B. Condições experimentais: $\mathrm{pH}=3$; [corante] $]_{0}=100 \mathrm{mg} \mathrm{L}^{-1}$; vazão de $\mathrm{O}_{2}=54 \mathrm{~L} \mathrm{~h}^{-1}$.

Figura 16. Variação da concentração de carbono orgânico total em função do tempo de ozonização de uma solução do corante Preto Remazol B com diferentes pHs iniciais. Condições experimentais: [corante] $]_{0}=100 \mathrm{mg} \mathrm{L}^{-1}$; vazão de $\mathrm{O}_{2}=54 \mathrm{~L} \mathrm{~h}^{-1}$.

Figura 17. Variação do pH em função do tempo de ozonização de uma solução do corante Preto Remazol B com diferentes pHs iniciais. Condições experimentais: [corante] $]_{0}=100 \mathrm{mg} \mathrm{L}^{-1}$; vazão de $\mathrm{O}_{2}=54 \mathrm{~L} \mathrm{~h}^{-1}$.

Figura 18. Variação do ozônio consumido em função do tempo de ozonização de uma solução do corante Preto Remazol B. Condições experimentais: $\mathrm{pH}=3$; [corante] $]_{0}=100 \mathrm{mg} \mathrm{L}^{-1}$; vazão de $\mathrm{O}_{2}=54 \mathrm{~L} \mathrm{~h}^{-1}$.

Figura 19. Variação da quantidade de ozônio consumido em função da concentração mineralizada de uma solução do corante Preto Remazol B. Condições experimentais: $\mathrm{pH}=3$; [corante] $]_{0}=100 \mathrm{mg} \mathrm{L}^{-1}$; vazão de $\mathrm{O}_{2}=54 \mathrm{~L} \mathrm{~h}^{-1}$.

Figura 20. Variação da concentração de carbono orgânico total em função do tempo de ozonização de uma solução do corante Preto Remazol B usando uma concentração de $10,0 \times 10^{-3} \mathrm{~mol} \mathrm{~L}^{-1}$ de peróxido de hidrogênio. Condições experimentais: $\mathrm{pH}=3$; [corante] $]_{0}=100 \mathrm{mg}$ $\mathrm{L}^{-1}$; vazão de $\mathrm{O}_{2}=54 \mathrm{~L} \mathrm{~h}^{-1}$. 
Figura 21. Variação da concentração do carbono orgânico total em função da concentração de peróxido de hidrogênio de uma solução do corante Preto Remazol B após 30 minutos de ozonização. Condições experimentais: $\mathrm{pH}=3$; $[\text { corante }]_{0}=100 \mathrm{mg} \mathrm{L}^{-1}$; vazão de $\mathrm{O}_{2}=54 \mathrm{~L} \mathrm{~h}^{-1}$.

Figura 22. Variação da concentração de carbono orgânico total em função do tempo de ozonização de uma solução do corante Preto Remazol B na ausência e presença de uma concentração de $1,00 \times 10^{-5}$ mol L $\mathrm{L}^{-1}$ de manganês. Condições experimentais: $\mathrm{pH}=3$; [corante] $]_{0}=$ $100 \mathrm{mg} \mathrm{L}^{-1}$; vazão de $\mathrm{O}_{2}=54 \mathrm{~L} \mathrm{~h}^{-1}$.

Figura 23. Variação da concentração do carbono orgânico total em função da concentração de manganês de uma solução do corante Preto Remazol B após 30 minutos de ozonização. Condições experimentais: $\mathrm{pH}=3 ;$ corante $]_{0}=100 \mathrm{mg} \mathrm{L}^{-1}$; vazão de $\mathrm{O}_{2}=54 \mathrm{~L} \mathrm{~h}^{-1}$.

Figura 24. Variação da concentração do carbono orgânico total em função do tempo de ozonização de uma solução do corante Preto Remazol B em diferentes concentrações de óxido de manganês. Condições experimentais: $\mathrm{pH}=3$; [corante] $0=100 \mathrm{mg} \mathrm{L}^{-1}$; vazão de $\mathrm{O}_{2}$ $=54 \mathrm{~L} \mathrm{~h}^{-1}$.

Figura 25. Variação da concentração de carbono orgânico total de uma solução do corante Preto Remazol B durante a ozonização em pH 3 sem ( $\bullet$ ) e com a na presença de $1,00 \times 10^{-5} \mathrm{~mol} \mathrm{~L}^{-1}$ de $\mathrm{Mn}^{2+}(\bullet) ; 5,00 \times$ $10^{-3} \mathrm{~mol} \mathrm{~L}^{-1}$ de $\mathrm{H}_{2} \mathrm{O}_{2}(\boldsymbol{\Delta})$ e $1,00 \times 10^{-5} \mathrm{~mol} \mathrm{~L}^{-1} \mathrm{Mn}^{2+} / 5 \times 10^{-3} \mathrm{~mol} \mathrm{~L}^{-1} \mathrm{H}_{2} \mathrm{O}_{2}$ $(\boldsymbol{\nabla})$. Condições experimentais: $\mathrm{pH}=3$; [corante] $]_{0}=100 \mathrm{mg} \mathrm{L}^{-1}$; vazão de $\mathrm{O}_{2}=54 \mathrm{~L} \mathrm{~h}^{-1}$.

Figura 26. Variação da concentração de carbono orgânico total em função do tempo de ozonização de uma solução do corante Preto Remazol B empregando-se $1,00 \times 10^{-4} \mathrm{~mol} \mathrm{~L}^{-1}$ de $\mathrm{Mn}^{2+}$ e diferentes concentrações de $\mathrm{H}_{2} \mathrm{O}_{2}$. Condições experimentais: $\mathrm{pH}=3$; [corante] $0=$ $100 \mathrm{mg} \mathrm{L}^{-1}$; vazão de $\mathrm{O}_{2}=54 \mathrm{~L} \mathrm{~h}^{-1}$.

Figura 27. Variação da concentração do carbono orgânico total em função da concentração de ferro (II) e de ferro (III) de uma solução do corante Preto Remazol B após $30 \mathrm{~min}$ de ozonização. Condições experimentais: $\mathrm{pH}=3$; [corante] $]_{0}=100 \mathrm{mg} \mathrm{L}^{-1}$; vazão de $\mathrm{O}_{2}=54 \mathrm{~L} \mathrm{~h}^{-1}$. 
Figura 28. Variação da concentração do carbono orgânico total em função do tempo de ozonização de uma solução do corante Preto Remazol B na presença de uma concentração de $1,00 \times 10^{-4} \mathrm{~mol} \mathrm{~L}^{-1}$ ferro (III). Condições experimentais: $\mathrm{pH}=3$; [corante] $]_{0}=100 \mathrm{mg} \mathrm{L}^{-1}$; vazão de $\mathrm{O}_{2}=54 \mathrm{~L} \mathrm{~h}^{-1}$.

Figura 29. Variação da concentração do carbono orgânico total em função da concentração de ferro (III) de uma solução do corante Preto Remazol B após 30 min de processo. Condições experimentais: $\mathrm{pH}=3$; [corante] $]_{0}=100 \mathrm{mg} \mathrm{L}^{-1}$; vazão de $\mathrm{O}_{2}=54 \mathrm{~L} \mathrm{~h}^{-1}$.

Figura 30. Espectro UV-Vis de uma solução do corante Azul Remazol Brilhante RN (a) Turquesa Remazol (b) após diferentes tempos de ozonização. Condições experimentais: $\mathrm{pH}=3$; [corante $]_{0}=100 \mathrm{mg} \mathrm{L}^{-1}$; vazão de $\mathrm{O}_{2}=54 \mathrm{~L} \mathrm{~h}^{-1}$.

Figura 31. Variação da concentração do carbono orgânico total em função do tempo de ozonização de uma solução do corante Azul Remazol Brilhante RN usando diferentes métodos de ozonização. Condições experimentais: $\mathrm{pH}=3$; [corante] $0=100 \mathrm{mg} \mathrm{L}^{-1}$; vazão de $\mathrm{O}_{2}$ $=54 \mathrm{~L} \mathrm{~h}^{-1}$.

Figura 32. Variação da concentração do carbono orgânico total em função do tempo de ozonização de uma solução do corante Turquesa Remazol G133 usando diferentes processos de ozonização. Condições experimentais: $\mathrm{pH}=3$; [corante $]_{0}=100 \mathrm{mg} \mathrm{L}^{-1}$; vazão de $\mathrm{O}_{2}=54 \mathrm{~L} \mathrm{~h}^{-1}$.

Figura 33. Resultados da porcentagem da variação da concentração do carbono orgânico total após 30 minutos de ozonização de uma solução de corante nos diferentes processos em estudo. Condições experimentais: $\mathrm{pH}=3$; $[\text { corante }]_{0}=100 \mathrm{mg} \mathrm{L}^{-1}$; vazão de $\mathrm{O}_{2}=54 \mathrm{~L} \mathrm{~h}^{-1}$.

Figura 34. Variação da concentração do carbono orgânico total em função do tempo de ozonização de uma solução do corante Preto Remazol B em diferentes condições de sílica. Condições experimentais: $\mathrm{pH}=3$; $[\text { corante }]_{0}=100 \mathrm{mg} \mathrm{L}^{-1} ;$ vazão de $\mathrm{O}_{2}=54 \mathrm{~L} \mathrm{~h}^{-1}$. 
Figura 35. Variação da concentração do carbono orgânico total em função do tempo de ozonização de uma solução do corante Preto Remazol B na presença de manganês nas concentrações de $2,5 \%$ e $5,0 \%$. Condições experimentais: $\mathrm{pH}=3$; [corante] $]_{0}=100 \mathrm{mg} \mathrm{L}^{-1}$; vazão de $\mathrm{O}_{2}=54 \mathrm{~L} \mathrm{~h}^{-1}$.

Figura 36. Variação da concentração do carbono orgânico total em função do tempo de ozonização de uma solução do corante Preto Remazol B das diferentes concentrações de manganês $(1,5,2,5,3,5$ e $5,0 \%$ ). Condições experimentais: $\mathrm{pH}=3$; [corante] $0=100 \mathrm{mg} \mathrm{L}^{-1}$; vazão de $\mathrm{O}_{2}=54 \mathrm{~L} \mathrm{~h}^{-1}$. 


\section{ÍNDICE DE TABELAS}

Tabela 1. Constantes cinéticas da interação de alguns compostos orgânicos com o ozônio e com o radical hidroxila.

Tabela 2. Descrição dos corantes avaliados neste estudo.

Tabela 3. Características iniciais do efluente da indústria têxtil.

Tabela 4. Variação da constante aparente de remoção de COT do processo de ozonização do corante Preto Remazol B em diferentes pHs iniciais. Condições experimentais: [corante] $]_{0}=100 \mathrm{mg} \mathrm{L}^{-1}$; vazão de $\mathrm{O}_{2}$ $=54 \mathrm{~L} \mathrm{~h}^{-1}$.

Tabela 5. Variação da razão de consumo de ozônio em função do pH inicial da solução de Preto Remazol B.

Tabela 6. Variação das constantes aparentes de remoção de COT com a concentração de manganês.

Tabela 7. Porcentagem de remoção de carbono orgânico total em função da concentração de peróxido de hidrogênio e de manganês após 30 minutos de ozonização.

Tabela 8. Variação da taxa de mineralização em função da 69 concentração de íon manganês (II) e de peróxido no processo $\mathrm{O}_{3} / \mathrm{pH} 3 / \mathrm{Mn}^{2+} / \mathrm{H}_{2} \mathrm{O}_{2}$.

Tabela 9. Efeito da concentração de ferro (II) e ferro (III) na variação da constante aparente de remoção de COT e na mineralização em 30 minutos de tratamento.

Tabela 10. Variação de $k_{\text {obs }}$, $k_{\text {cons }}$ e a $\%$ mineralização para os diferentes métodos aplicados ao azocorante modelo.

Tabela 11. Variação da constante aparente de remoção de COT para os corantes Azul Brilhante RN e Turqueza Remazol G133 com o processo de ozonização empregado. 


\section{INTRODUÇÃO}

Desde as últimas décadas do século passado, a sociedade tem adquirido uma conscientização crescente a respeito dos problemas ambientais e seus efeitos para a qualidade de vida desta e das futuras gerações. Apesar disso, a integridade de vários ecossistemas vem sendo afetada, de uma maneira preocupante, por uma série de atividades antropogênicas, levando a um risco de degradação irreversível do meio ambiente.

\subsection{Problemática da água}

Neste panorama, as preocupações com o uso e a qualidade da água adquirem especial importância devido à relevância deste recurso e ao aumento desenfreado em sua demanda, resultante principalmente do crescimento acelerado da população e do estilo de vida da sociedade contemporânea (que, dentre outras coisas, prima por padrões de conforto e bem-estar em detrimento do equilíbrio dos recursos naturais). De fato é difícil imaginar qualquer tipo de organização dos seres humanos em sociedade que dispense o uso da água, uma vez que esta substância é essencial não somente para a manutenção das atividades biológicas básicas (a água compõe parte significativa das células de todos os seres vivos, estando envolvida em processos de transporte de nutrientes e dejetos; manutenção de temperatura; produção e armazenamento de energia, etc.), mas também para o desenvolvimento das atividades produtivas (agrícolas ou industriais) $)^{1,2}$.

Talvez por ser relativamente abundante, recobrindo em torno de $75 \%$ da superfície do nosso planeta, a água tornou-se tão banal que sua presença, 
embora indispensável, não despertou a merecida atenção e valorização. Não obstante, devido à água ser um recurso natural renovável (qualquer que seja o seu uso, no final ela é restituída ao ambiente/origem) durante muito tempo teve-se uma concepção errônea de inesgotabilidade desta substância. Embora seja verdade que o homem não faça a água simplesmente desaparecer da natureza (como tem feito com as florestas e algumas reservas minerais) a qualidade de uma infinidade de recursos hídricos tem sido seriamente comprometida restringindo muito suas utilizações ${ }^{1,2}$.

Dentre as várias atividades antrópicas que têm contribuído para a degradação da qualidade das águas, a atividade industrial é, sem dúvida alguma, uma das principais fontes de poluição. Isto se deve, dentre vários fatores, à ineficiência dos processos produtivos (a produção/transformação de materiais não é $100 \%$ eficaz, levando à presença inerente de sub-produtos e/ou matéria-prima). Além disso, os processos industriais geralmente utilizam grandes volumes de água, que podem levar à contaminação de corpos d'água, sobretudo pela dificuldade para se tratar grandes quantidades de efluentes. Finalmente, a variedade de compostos oriundos dos processos industriais, que podem comprometer a qualidade de nossas águas é enorme, indo desde compostos inorgânicos (como os metais pesados) até várias classes de compostos orgânicos (compostos aromáticos, nitrogenados, halogenados, alifáticos, etc), o que praticamente inviabiliza o desenvolvimento de sistemas de tratamento de efluentes que sejam universais (capazes de serem empregados na degradação de qualquer tipo de resíduo) $)^{3,4}$. 


\subsection{Indústria têxtil e processos de tratamento}

Uma importante parcela do processo de contaminação dos corpos d'água no Brasil pode ser atribuída às atividades das refinarias de petróleo, indústrias químicas, têxteis e papeleiras. Em função deste panorama, muitos estudos têm sido realizados buscando desenvolver tecnologias capazes de minimizar o volume e a toxicidade dos efluentes industriais ${ }^{3}$.

Dentro deste contexto, o setor têxtil apresenta um especial destaque, devido a seu grande parque industrial instalado e à geração de grandes volumes de efluentes, os quais, quando não corretamente tratados, podem causar sérios problemas de contaminação ambiental ${ }^{5}$. Na indústria têxtil, o processo que leva a formação de grandes volumes de efluentes é o processo de tingimento, sendo que este pode ser dividido em três etapas consideradas importantes: a montagem, a fixação e o tratamento final. A fixação do corante à fibra é feita através de reações químicas e ocorre usualmente em diferentes etapas. Entretanto, o processo de tingimento envolve, como operação final, uma etapa de lavagem para a retirada do excesso dos corantes não fixados às fibras nas etapas procedentes $^{6}$. Desta maneira, os efluentes têxteis caracterizam-se por serem altamente coloridos, devido à presença de corantes que não se fixam na fibra durante o processo de tingimento; estima-se que aproximadamente $30 \%$ dos corantes são descarregados como efluentes nos corpos d'água ${ }^{5}$.

A importância dos corantes para a civilização humana é evidente e bem documentada ${ }^{5}$. Os corantes sintéticos são extensivamente utilizados na indústria têxtil, gráfica, fotográfica e como aditivo em derivados de petróleo, dentre outras aplicações. Aproximadamente 10.000 diferentes corantes e pigmentos são 
usados industrialmente e estima-se que, atualmente, 2.000 tipos de corantes estão disponíveis para a indústria têxtil. Essa diversidade é justificada, uma vez que cada tipo de fibra a ser colorida requer corantes com características próprias e bem definidas. Em 2000, os corantes representavam um consumo anual de cerca de $7 \times 10^{5}$ tons no mundo e 26.500 tons somente no Brasil ${ }^{5,6}$, sendo que esta demanda é crescente, principalmente em função do crescimento econômico e populacional.

A molécula de corante utilizada para tingimento da fibra têxtil pode ser dividida em duas partes principais: o grupo cromóforo e a estrutura responsável pela fixação à fibra. Existem vários grupos cromóforos utilizados atualmente na síntese de corantes. No entanto, o grupo mais representativo e largamente empregado pertence à família dos azocorantes, que se caracterizam por apresentarem um ou mais grupamentos $-\mathrm{N}=\mathrm{N}$ - ligados a sistemas aromáticos. Os azocorantes representam cerca de $60 \%$ dos corantes atualmente utilizados no mundo, sendo extensivamente utilizados no tingimento de fibras têxteis ${ }^{5}$.

Além disso, os corantes também podem ser classificados segundo sua fixação, como por exemplo: ácido, direto, básico, de enxofre e reativos, sendo este último o mais utilizado em nível mundial. Os corantes reativos são assim chamados devido a sua capacidade de formarem ligações covalentes com a fibra. Estes corantes podem ser utilizados no tingimento de fibras celulósicas com boas características de tingimento, solidez e estabilidade química ${ }^{5}$.

A poluição dos corpos d'água com estes compostos provoca, além da poluição visual, alterações em ciclos biológicos afetando principalmente, processos de fotossíntese. Além deste fato, algumas classes de corantes, 
principalmente os azocorantes e seus subprodutos, podem ser carcinogênicos e mutagênicos ${ }^{5}$. Devido a estas implicações ambientais, novas tecnologias têm sido buscadas para a degradação destes compostos em efluentes têxteis.

Em geral, na indústria têxtil os processos de tratamento de efluentes estão fundamentados na operação de sistemas físico-químicos de precipitaçãocoagulação, seguidos de tratamento biológico via sistema de lodos ativados (Figura 1).

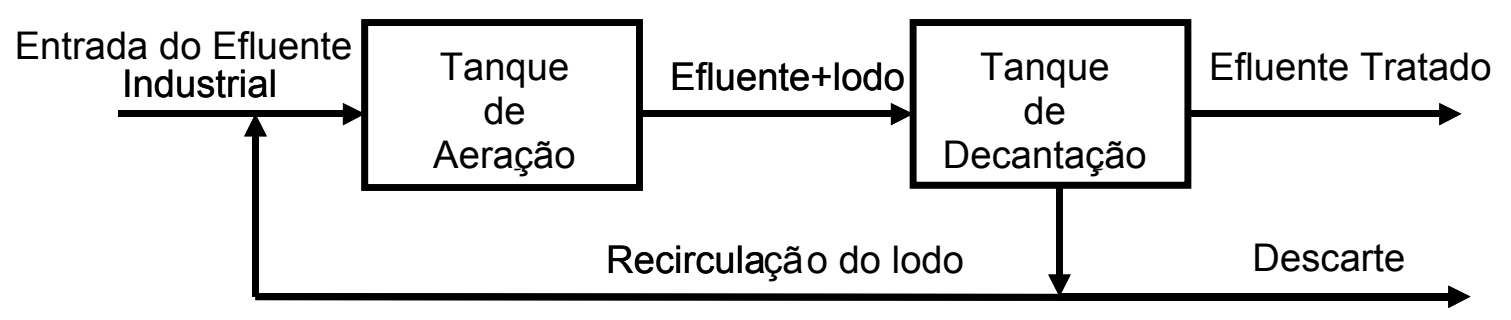

Figura 1. Representação esquemática de uma estação de tratamento de efluentes por lodos ativados, tipicamente empregados para o tratamento de efluentes têxteis.

Este processo consiste na agitação dos efluentes na presença de microorganismos e ar, durante o tempo necessário para metabolizar e flocular uma grande parte da matéria orgânica ${ }^{7}$. O sistema apresenta uma eficiência relativamente alta, permitindo a remoção de aproximadamente $80 \%$ da carga de corantes. Infelizmente, o problema relacionado com o acúmulo de lodo torna-se crítico, uma vez que o teor de corantes adsorvidos é bastante elevado, impedindo qualquer possibilidade de reaproveitamento do lodo.

O emprego de processos oxidativos avançados - POA (de forma isolada, 
combinada ou preliminar a outros tratamentos) tem apresentado boas perspectivas para a depuração efetiva de uma série de espécies químicas poluentes ${ }^{3,5}$. Os POA são baseados na geração do radical hidroxila $(\cdot \mathrm{OH})$ que tem alto poder oxidante $\left(E^{\circ} \cong+3,06 \mathrm{~V}\right)$ e podem promover a degradação de uma ampla gama de compostos poluentes em poucos minutos. Os radicais hidroxila podem ser gerados através de reações envolvendo oxidantes fortes, como ozônio $\left(\mathrm{O}_{3}\right)$, peróxido de hidrogênio $\left(\mathrm{H}_{2} \mathrm{O}_{2}\right)$, semicondutores, como dióxido de titânio $\left(\mathrm{TiO}_{2}\right)$ e óxido de zinco $(\mathrm{ZnO})$ e irradiação ultravioleta (UV). Os processos que contam com a presença de catalisadores sólidos são chamados heterogêneos, enquanto que os demais são chamados homogêneos. As vantagens mais significativas deste tipo de procedimento estão representadas pela grande eficiência na degradação de compostos orgânicos tóxicos, sem a necessidade de recorrer à utilização de outros oxidantes químicos intrinsecamente poluentes ${ }^{8-12}$.

Particularmente, para o tratamento de efluentes têxteis, o ozônio apresenta-se muito atrativo e com um amplo campo de aplicação. Como os grupos cromóforos das moléculas de corantes são compostos orgânicos policíclicos, com ligações insaturadas e/ou presença de heteroátomos nucleófilos, estas ligações podem ser clivadas eficientemente pelo eletrófilo $\mathrm{O}_{3}$, dando origem a outras moléculas menores, perdendo suas características iniciais como cor, toxicidade, etc ${ }^{13}$.

\subsection{Ozônio}

O ozônio vem sendo utilizado no tratamento e desinfecção de águas desde o início do século $X X^{14}$. Dentre as várias motivações para seu emprego neste tipo 
de aplicação, destacam-se duas: é um forte agente oxidante $\left(E^{0} \cong 2,1 \mathrm{~V}\right)$ e não é uma fonte intrínseca de poluição. A primeira propriedade permite que o ozônio possa oxidar uma série de compostos inorgânicos e orgânicos. De fato, dentre as substâncias químicas ordinárias, somente o flúor $\left(\mathrm{E}^{0} \cong 3,0 \mathrm{~V}\right)$ possui um potencial de redução maior que o ozônio ${ }^{15}$. Outros oxidantes normalmente empregados, tais como: $\mathrm{KMnO}_{4}\left(\mathrm{E}^{0} \cong 1,7 \mathrm{~V}\right)$ e $\mathrm{Cl}_{2}\left(\mathrm{E}^{0} \cong 1,4 \mathrm{~V}\right)^{15}$, costumam levar à formação de sub-produtos (íons de metais pesados e compostos organoclorados, respectivamente), que podem ser inclusive mais tóxicos que os compostos poluentes originais. Aqui se evidencia a segunda propriedade vantajosa do ozônio, pois seu produto preferencial de degradação é o oxigênio, um produto não poluente e indispensável para as atividades biológicas aeróbias dos ecossistemas aquáticos ${ }^{16}$.

A molécula de ozônio possui uma geometria triangular, onde o átomo de oxigênio central utiliza orbitais $\mathrm{sp}^{2}$ para formar ligações $\sigma$ com os demais oxigênios. Os orbitais $p_{z}$ dos três oxigênios são utilizados para formar uma ligação $\pi$ deslocalizada, sendo que as duas ligações desta molécula são equivalentes, com comprimentos iguais e ordem de ligação igual a 1,5 $5^{17}$. Devido a este arranjo, o ozônio é dipolar e pode reagir como um agente eletrofílico ou nucleofílico. De um modo geral, nas reações de degradação de compostos orgânicos poluentes, o ozônio tende a reagir preferencialmente com compostos insaturados (alquenos, alquinos, anéis aromáticos, etc). De fato, o ozônio é o reagente clássico usado em reações orgânicas para quebrar ligações duplas carbono-carbono, via o mecanismo de Criegee (ou simplesmente ozonólise), conforme esquema apresentado na Figura $2^{14,18}$. 
(A)<smiles>CC(C)=C(C)C</smiles><smiles>CC1COCCOC1(C)C</smiles>

(B)
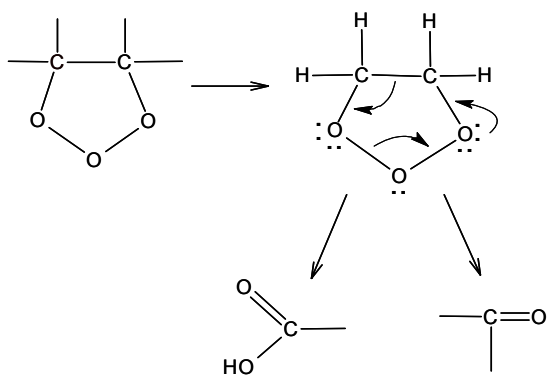<smiles>COOC1(OOc2cccc(O)c2)C=CC=CC1O</smiles>

Figura 2. Reação direta do ozônio com a matéria orgânica: mecanismo de Criegee (A). Exemplo do ataque eletrofílico do $\mathrm{O}_{3}$ a um composto aromático $(B)^{18}$.

Assim, a oxidação direta de compostos orgânicos por ozônio é uma reação seletiva e que muitas vezes apresenta cinéticas relativamente lentas, com valores típicos entre $10^{-1}$ e $10^{3} \mathrm{~L} \mathrm{~mol}^{-1} \mathrm{~s}^{-1}$ dependendo das espécies envolvidas (Tabela $1)^{14,19-21}$. Compostos aromáticos com grupos substituintes desativantes, como o cloro, sofrem ozonólise mais lentamente que compostos aromáticos com grupos substituintes ativantes, como o grupo hidroxila. Em geral, as formas ionizadas ou dissociadas dos compostos orgânicos reagem muito mais rapidamente com o ozônio que as formas neutras (não dissociadas) ${ }^{18}$. Além disso, as reações de ozonólise direta não costumam promover a oxidação completa dos compostos orgânicos até $\mathrm{CO}_{2}$ e $\mathrm{H}_{2} \mathrm{O}$, sendo aldeídos, cetonas, álcoois e ácidos carboxílicos os principais produtos deste tipo de reação ${ }^{14}$. 
Tabela 1. Constantes cinéticas da interação de alguns compostos orgânicos com o ozônio e com o radical hidroxila ${ }^{14}$.

\begin{tabular}{|l|cc|}
\hline \multicolumn{1}{|c|}{ Soluto } & $k_{O_{3}}\left(\mathrm{M}^{-1} \mathrm{~s}^{-1}\right)$ & $k_{\mathrm{OH}}\left(\mathrm{M}^{-1} \mathrm{~s}^{-1}\right)$ \\
\hline Benzeno & 2 & $7,8 \times 10^{9}$ \\
Nitrobenzeno & 0,09 & $3,9 \times 10^{9}$ \\
Tolueno & 14 & $3,0 \times 10^{9}$ \\
Xileno & 94 & $7,5 \times 10^{9}$ \\
Ácido fórmico & 5 & $1,3 \times 10^{8}$ \\
Ílon formato & 100 & $3,2 \times 10^{9}$ \\
Ácido oxálico & $4 \times 10^{-2}$ & $1,4 \times 10^{6}$ \\
Ín oxalato & $4 \times 10^{-2}$ & $7,7 \times 10^{6}$ \\
Ácido acético & $3 \times 10^{-5}$ & $1,6 \times 10^{7}$ \\
İon acetato & $3 \times 10^{-5}$ & $8,5 \times 10^{7}$ \\
Ácido succínico & $4 \times 10^{-2}$ & $3,1 \times 10^{8}$ \\
Íon succinato & $3 \times 10^{-2}$ & $3,1 \times 10^{8}$ \\
Ácido salicílico & 500 & $2,2 \times 10^{10}$ \\
Íon salicilato & $3 \times 10^{3}$ & $1,6 \times 10^{10}$ \\
\hline
\end{tabular}

A limitação cinética, alta seletividade na degradação e baixa eficiência na mineralização de compostos poluentes podem ser contornadas fazendo-se uso da alta reatividade e das reações indiretas do ozônio em meio aquoso. $\mathrm{O}_{3} \mathrm{O}_{3}$ é termodinamicamente instável, sendo sua decomposição catalisada por vários materiais $^{22-25}$. Em meio aquoso, o principal desencadeador da decomposição do ozônio é o ânion hidroxila $\left(\mathrm{OH}^{-}\right)$, sendo que a reação entre $\mathrm{O}_{3}$ e $\mathrm{OH}^{-}$induz uma série de reações radicalares que levam à formação de radicais hidroxila. Tal rota de reação é bastante complexa e pode ser influenciada por uma série de fatores experimentais e natureza/concentração de espécies químicas presentes. De uma maneira simplificada, o mecanismo pode ser dividido em três partes, conforme descrito a seguir e na Figura $3^{14,26,27}$. 


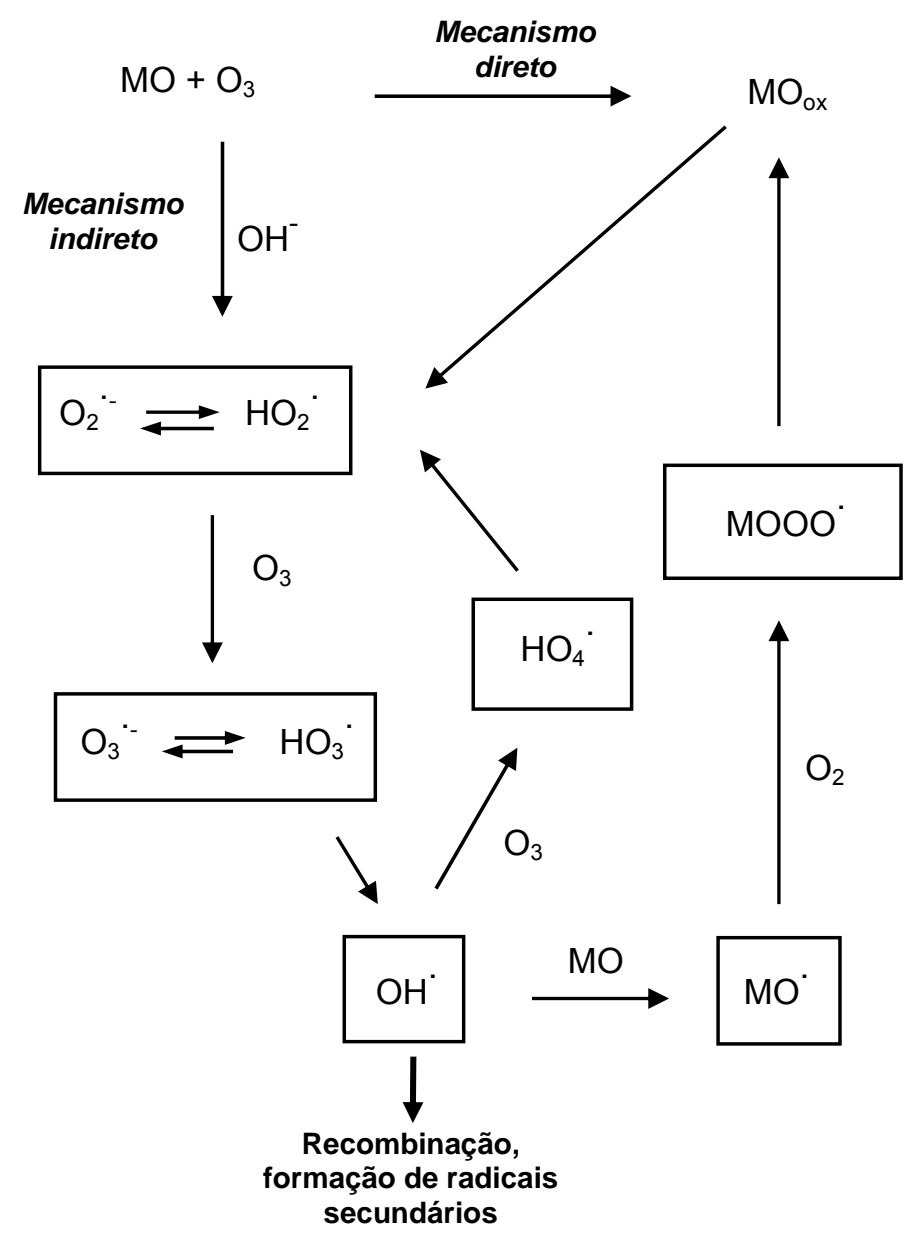

Figura 3. Mecanismos de reação direto e indireto do ozônio com a matéria orgânica em meio aquoso ( $\mathrm{MO}=$ matéria orgânica; $\mathrm{MO}_{\mathrm{ox}}=$ matéria orgânica oxidada $)^{14}$.

$\underline{\text { Iniciação }}$

A reação entre o íon hidroxila e o ozônio leva a formação do ânion radical superóxido $\left(\mathrm{O}_{2}{ }^{-}\right)$e do radical hidroperoxila $\left(\mathrm{HO}_{2}{ }^{-}\right)$:

$$
\mathrm{O}_{3}+\mathrm{OH}^{-} \rightarrow \mathrm{O}_{2}^{-}+\mathrm{HO}_{2}
$$

O radical hidroperoxila apresenta um equilíbrio ácido-base:

$$
\mathrm{HO}_{2} \rightleftarrows \mathrm{O}_{2}{ }^{-}+\mathrm{H}^{+}
$$

\section{Propagação}

O ânion radical ozonóide $\left(\mathrm{O}_{3}^{-}{ }^{-}\right)$, formado da reação entre o ozônio e o ânion 
radical superóxido, decompõe-se, muito rapidamente, para formar os radicais hidroxila $(\mathrm{OH})$ :

$$
\begin{aligned}
& \mathrm{O}_{3}+\mathrm{O}_{2}^{\cdot-} \rightarrow \mathrm{O}_{3}^{\cdot-}+\mathrm{O}_{2} \\
& \mathrm{HO}_{3} \rightleftarrows \mathrm{O}_{3}^{\cdot-}+\mathrm{H}^{+} \\
& \mathrm{HO}_{3} \cdot \mathrm{OH}+\mathrm{O}_{2}
\end{aligned}
$$

$\mathrm{O} \mathrm{OH}$ pode reagir com o ozônio da seguinte maneira:

$$
\begin{aligned}
& \mathrm{OH}+\mathrm{O}_{3} \rightarrow \mathrm{HO}_{4} \\
& \mathrm{HO}_{4} \rightarrow \mathrm{O}_{2}+\mathrm{HO}_{2}
\end{aligned}
$$

Com o decaimento de $\mathrm{HO}_{4}$ para $\mathrm{O}_{2}$ e $\mathrm{HO}_{2}$ a reação em cadeia pode começar de novo. Substâncias que convertem $\mathrm{OH}$ para radicais $\mathrm{O}_{2}{ }^{-{ }^{-}}$e/ou $\mathrm{HO}_{2}{ }^{\cdot}$ promovem a reação em cadeia e devido a isto são chamadas de promotores.

Moléculas orgânicas, $\mathrm{R}$, também podem agir como promotores:

$$
\mathrm{H}_{2} \mathrm{R}+\mathrm{OH} \rightarrow \mathrm{HR}+\mathrm{H}_{2} \mathrm{O}
$$

Se o oxigênio está presente, radicais orgânicos peroxi (ROO) podem ser formados. $E$ estes podem reagir em seguida, eliminando $\mathrm{O}_{2}{ }^{-} / \mathrm{HO}_{2}$ e entrando na reação em cadeia:

$$
\begin{aligned}
& \mathrm{HR}+\mathrm{O}_{2} \rightarrow \mathrm{HRO}_{2} \\
& \mathrm{HRO}_{2} \rightarrow \mathrm{R}+\mathrm{HO}_{2} \\
& \mathrm{HRO}_{2} \rightarrow \mathrm{RO}+\mathrm{OH}
\end{aligned}
$$

\section{$\underline{\text { Terminação }}$}

Algumas substâncias orgânicas e inorgânicas reagem com o radical hidroxila e formam radicais secundários que não produzem $\mathrm{O}_{2}{ }^{-} / \mathrm{HO}_{2}$, atuando como inibidores das reações em cadeia: 


$$
\begin{aligned}
& \mathrm{OH}^{-}+\mathrm{CO}_{3}{ }^{2-} \rightarrow \mathrm{OH}^{-}+\mathrm{CO}_{3}{ }^{--} \\
& \mathrm{OH}+\mathrm{HCO}_{3}^{-} \rightarrow \mathrm{OH}^{-}+\mathrm{HCO}_{3} .
\end{aligned}
$$

Uma outra possibilidade para reação de terminação é a reação entre dois radicais:

$$
\mathrm{OH}+\mathrm{HO}_{2} \rightarrow \mathrm{O}_{2}+\mathrm{H}_{2} \mathrm{O}
$$

A combinação destas reações mostra que três moléculas de ozônio podem produzir dois radicais hidroxilas:

$$
3 \mathrm{O}_{3}+\mathrm{OH}^{-}+\mathrm{H}^{+} \rightarrow 2 \mathrm{OH}^{-}+4 \mathrm{O}_{2}
$$

O radical hidroxila é um dos radicais livres mais reativos e um dos agentes oxidantes mais fortes que se tem notícia $\left(E^{0} \cong 2,7 \mathrm{~V}\right)^{15}$. Outra característica dos radicais hidroxila, que os tornam muito eficientes para degradar compostos poluentes, é a sua rápida cinética de reação, para compostos orgânicos observam-se constantes entre $10^{6}$ e $10^{10} \mathrm{~L} \mathrm{~mol}^{-1} \mathrm{~s}^{-1}$ (conforme mostrado na Tabela 1), ou seja, atingem valores da mesma ordem de grandeza da constante de difusão do $\mathrm{OH}$ em meio aquoso $\left(\mathrm{k}_{\text {dif }}=7 \times 10^{9} \mathrm{~L} \mathrm{~mol}^{-1} \mathrm{~s}^{-1}\right)$. Além disso, esta espécie é bem menos seletiva que o ozônio, sendo capaz de oxidar uma ampla gama de compostos ${ }^{3,18,28}$. Devido a estas vantagens, o emprego do ozônio visando à formação de radicais hidroxila (ou seja, atuando como um processo oxidativo avançado - POA) é muito mais versátil e costuma ser a forma mais empregada, principalmente, por ser muito eficiente para promover a completa oxidação (mineralização) dos compostos orgânicos poluentes.

Várias abordagens podem ser utilizadas com este intuito, dentre elas destacam-se o uso combinado do ozônio com $\mathrm{OH}^{-}$, radiação $U V, \mathrm{H}_{2} \mathrm{O}_{2}$, ultra-som, 
etc. A variação do $\mathrm{pH}$ costuma ser a abordagem mais simples (embora não seja a mais eficiente) para se obter a geração de radicais hidroxila a partir do ozônio. Geralmente, sob condições ácidas (principalmente em $\mathrm{pH} \leq 4$ ) o mecanismo direto (reação de ozonólise) predomina, porém acima de pH 10 ele se torna predominantemente indireto (reações radicalares). Para águas naturais, (superficiais ou subterrâneas) com $\mathrm{pH}$ em torno de 7 , ambos os mecanismos podem estar presentes e outros fatores (como tipo do composto alvo e presença de metais de transição) contribuirão para definir a extensão de cada um deles ${ }^{10}$. A Figura 3 esquematiza as duas vias pelas qual o ozônio pode reagir com compostos orgânicos poluentes.

Se $\mathrm{H}_{2} \mathrm{O}_{2}$ é adicionado na solução, o precursor ${ }^{\circ} \mathrm{O}_{3}{ }^{-}$é produzido pela reação do $\mathrm{O}_{3}$ com o peróxido de hidrogênio. Esta reação pode ser cerca de 40.000 vezes mais rápida do que a reação do $\mathrm{O}_{3} \mathrm{com} \mathrm{OH}^{-}$. A reação geral deste processo pode ser esquematizada por:

$$
\mathrm{H}_{2} \mathrm{O}_{2}+2 \mathrm{O}_{3} \rightarrow 2 \cdot \mathrm{OH}+3 \mathrm{O}_{2}
$$

Em pH baixo, $\mathrm{H}_{2} \mathrm{O}_{2}$ reage somente muito lentamente com $\mathrm{O}_{3}$, mas em valores de $\mathrm{pH}$ acima de 5 , uma forte aceleração da decomposição de $\mathrm{O}_{3}$ por $\mathrm{H}_{2} \mathrm{O}_{2}$ é observada ${ }^{29}$. Arslan e colaboradores ${ }^{30}$ realizaram um estudo tratando um efluente têxtil sintético com o processo $\mathrm{O}_{3} / \mathrm{H}_{2} \mathrm{O}_{2}$ em 3 pHs diferentes e 7 diferentes concentrações de $\mathrm{H}_{2} \mathrm{O}_{2}$. Os resultados indicaram a presença de uma dose ótima de $\mathrm{H}_{2} \mathrm{O}_{2}$ para a máxima taxa de descolorização, sendo que a maior remoção de carbono orgânico foi obtida em $\mathrm{pH}$ 7,5. Os resultados mostram que acima de uma certa concentração de $\mathrm{H}_{2} \mathrm{O}_{2}$ não existe melhoramentos na eficiência do tratamento. As doses excedentes de $\mathrm{H}_{2} \mathrm{O}_{2}$ devem inibir a reação de 
oxidação com $\mathrm{H}_{2} \mathrm{O}_{2}$ agindo como consumidor de radicais:

$$
\begin{aligned}
& \mathrm{H}_{2} \mathrm{O}_{2}+\mathrm{OH} \rightarrow \mathrm{HO}_{2}+\mathrm{H}_{2} \mathrm{O} \\
& \mathrm{HO}_{2}+\mathrm{OH} \rightarrow \mathrm{OH}^{-}+\mathrm{HO}_{2}
\end{aligned}
$$

A ozonização fotolítica (presença de radiação, principalmente na região do ultravioleta) tem sido usada na oxidação de compostos fenólicos, álcoois e ácidos alifáticos com relativo sucesso ${ }^{31}$. A presença de radiação ultravioleta (UV) no processo de ozonização tem incrementado os parâmetros de degradação destes compostos em 10 a $10^{4}$ vezes $^{32}$ (equações 19 e 20 ):

$$
\begin{aligned}
& \mathrm{O}_{3}+\underset{h v}{\mathrm{~h}} \underset{\mathrm{H}}{\mathrm{h}} \underset{\mathrm{hv}}{\rightarrow} \mathrm{H}_{2} \mathrm{O}_{2}+\mathrm{O}_{2} \\
& \mathrm{H}_{2} \mathrm{O}_{2} \rightarrow 2 \cdot \mathrm{OH}
\end{aligned}
$$

Arslan e colaboradores ${ }^{30}$ mostraram que a eficiência do processo de tratamento $\mathrm{UV} / \mathrm{H}_{2} \mathrm{O}_{2}$, que envolve a combinação de radiação UV com água oxigenada aumenta com o aumento da concentração de $\mathrm{H}_{2} \mathrm{O}_{2}$ até um valor ótimo devido à absorção de uma fração maior de radiação UV por $\mathrm{H}_{2} \mathrm{O}_{2}$. Os autores concluíram que para degradação de corantes a eficiência dos POAs estudados depende da quantidade de $\mathrm{H}_{2} \mathrm{O}_{2}$ aplicada e/ou do $\mathrm{pH}$ do meio reacional.

Ghaly e colaboradores ${ }^{33}$ também empregaram os processos ozonização sozinha, $\mathrm{H}_{2} \mathrm{O}_{2} / \mathrm{O}_{3}$ e $\mathrm{H}_{2} \mathrm{O}_{2} / \mathrm{UV}$ na degradação de p-clorofenol. Os autores concluíram que em meio ácido, o ataque direto pela molécula de ozônio é predominante, enquanto que para pHs neutros e básicos a maior contribuição é do caminho radicalar. A presença de $\mathrm{H}_{2} \mathrm{O}_{2}$ ou de UV melhorou a taxa de degradação do p-clorofenol. 
Vários exemplos mostraram que o ozônio, quer reagindo de forma direta ou indireta (como um POA), apresenta bons resultados na desinfecção de águas para consumo humano ${ }^{34}$ e na degradação de uma série de compostos poluentes presentes em águas naturais e/ou efluentes, principalmente, os oriundos das indústrias têxteis, farmacêuticas, químicas e de papel e celulose ${ }^{3,35-37}$. Além da esterilização de uma série de organismos patogênicos, os efeitos depuradores do ozônio são mais pronunciados na remoção de cor (devido à degradação/oxidação de grupos cromóforos) e formação de moléculas menores com maior hidrofilicidade e menor toxicidade, pois as etapas oxidativas tendem a fragmentar macromoléculas poluentes ${ }^{38-40}$. Geralmente tais transformações contribuem para aumentar a (bio)degradabilidade dos compostos recalcitrantes aos tratamentos biológicos (transformação/oxidação dos poluentes a produtos mais facilmente metabolisados pelos microorganismos).

Embora alguns estudos mostrem que os processos de ozonização também podem promover certa redução na demanda química de oxigênio (DQO) e no teor de carbono orgânico total (COT), geralmente os níveis de redução de matéria orgânica são menores que os obtidos com outros POA ou necessitam de um dispêndio adicional de reagentes e/ou energia ${ }^{3,4}$, tornando-os desfavoráveis do ponto de vista econômico.

Devido a estas limitações, vários estudos vêm sendo realizados buscandose aumentar a eficiência dos processos de ozonização, principalmente com relação às taxas e graus de mineralização dos compostos orgânicos poluentes. Neste sentido, o uso do ozônio combinado com metais de transição em solução 
ou na forma sólida (suportes/sítios ativos heterogêneos) está sendo avaliado por diferentes grupos de pesquisa ${ }^{25,28,41-43}$.

\subsection{Ozonização catalítica homogênea}

Pesquisas recentes têm mostrado que a presença de metais de transição pode aumentar a eficiência da oxidação de uma série de espécies poluentes orgânicas por ozônio em meio aquoso ${ }^{25,28,41,44}$. Vários metais de transição podem ser empregados para este fim, dentre eles destacam-se: $\mathrm{Fe}, \mathrm{Mn}, \mathrm{Ni}, \mathrm{Co}, \mathrm{Cd}, \mathrm{Cu}$, $\mathrm{Ag}, \mathrm{Cr}$ e Zn. O tipo de metal de transição usado no processo de ozonização assistida e a natureza da matriz a ser remediada influem na velocidade da reação, na seletividade, no consumo de ozônio, na taxa de degradação/mineralização e no mecanismo de reação ${ }^{25}$.

Geralmente dois processos principais são considerados como hipóteses para o mecanismo da ozonização catalítica homogênea: 1) decomposição do ozônio pelo metal, seguido pela geração de radicais; e 2) a formação de complexos entre o catalisador e o composto orgânico, seguido por uma reação final de oxidação.

O processo de decomposição de ozônio por íons metálicos pode seguir diferentes mecanismos que, de um modo geral, levam à formação de radicais hidroxila. Hill ${ }^{45,46}$ encontrou evidências experimentais que mostram a geração de radicais hidroxila pela interação direta do ozônio com íons metálicos em meio aquoso:

$$
\mathrm{M}^{\mathrm{n}+}+\mathrm{O}_{3}+\mathrm{H}_{2} \mathrm{O} \rightarrow \mathrm{MOH}^{\mathrm{n}+}+\mathrm{O}_{2}+\mathrm{OH}
$$


O autor afirma ainda que o estado de oxidação original do metal pode ser restabelecido devido a reações paralelas com espécies radicalares, por exemplo: o radical hidroperoxila.

$$
\mathrm{HO}_{2}+\mathrm{MOH}^{\mathrm{n+}} \rightarrow \mathrm{M}^{\mathrm{n+}}+\mathrm{O}_{2}+\mathrm{H}_{2} \mathrm{O}
$$

Também há evidências que o íon metálico, presente em solução aquosa, pode iniciar a reação de decomposição do ozônio via geração do íon radical $\mathrm{O}_{2}{ }^{-}$. A transferência de elétrons de $\mathrm{O}_{2}^{-}$para a molécula de $\mathrm{O}_{3}$ conduz a formação de $\mathrm{O}_{3}{ }^{-}$(equação 3) e este por sua vez, conforme apresentado nas equações 4 e 5 leva à produção de radicais $\mathrm{OH}^{14}$.

Vários trabalhos ${ }^{47-49}$ mostram, por exemplo, que $\mathrm{Fe}^{2+}$ catalisa a decomposição de $\mathrm{O}_{3}$ para gerar radicais hidroxila seguindo um mecanismo distinto. Neste caso, o sistema catalítico $\mathrm{O}_{3} / \mathrm{Fe}^{2+}$ envolve a reação direta de $\mathrm{Fe}^{2+}$ com o ozônio levando à formação do intermediário $\mathrm{FeO}^{2+}$, espécie que promove a formação de $\mathrm{OH}$ :

$$
\begin{aligned}
& \mathrm{Fe}^{2+}+\mathrm{O}_{3} \rightarrow \mathrm{FeO}^{2+}+\mathrm{O}_{2} \\
& \mathrm{FeO}^{2+}+\mathrm{H}_{2} \mathrm{O} \rightarrow \mathrm{Fe}^{3+}+\mathrm{OH}+\mathrm{OH}^{-}
\end{aligned}
$$

O intermediário $\mathrm{FeO}^{2+}$ é também capaz de oxidar $\mathrm{Fe}^{2+}$ para $\mathrm{Fe}^{3+}$, mas com uma velocidade menor, e esta reação pode limitar a geração de radicais hidroxila, principalmente na presença de altas concentrações de $\mathrm{Fe}^{2+}$ :

$$
\mathrm{FeO}^{2+}+\mathrm{Fe}^{2+}+2 \mathrm{H}^{+} \rightarrow 2 \mathrm{Fe}^{3+}+\mathrm{H}_{2} \mathrm{O}
$$

A segunda maneira pela qual o ozônio pode interagir com os metais de transição (mecanismo de complexação) foi proposta por Pines e Reckhow ${ }^{33}$, baseada na ozonização de ácido oxálico na presença de $\mathrm{Co}(\mathrm{II})$ em pH 6. Numa primeira etapa, um complexo de Co(II)-oxalato é formado, sendo este 
posteriormente oxidado pelo ozônio, formando o complexo $\mathrm{Co}$ (III)-oxalato. Estes autores mostraram que o ataque do ozônio é preferencialmente sobre o centro metálico e a doação parcial de densidade eletrônica do oxalato para o cobalto (II) contribui para aumentar a reatividade do sistema Co(II)-oxalato quando comparado com o cobalto livre. O ciclo catalítico é finalizado com a decomposição do complexo de Co(III) e a formação de Co(II) e o radical oxalato.

$$
\begin{aligned}
& \mathrm{Co}^{2+}+\mathrm{C}_{2} \mathrm{O}_{4}{ }^{2-} \rightleftarrows \mathrm{CoC}_{2} \mathrm{O}_{4} \\
& \mathrm{CoC}_{2} \mathrm{O}_{4}+\mathrm{O}_{3} \rightarrow \mathrm{CoC}_{2} \mathrm{O}_{4}{ }^{+}+\mathrm{O}_{3}^{-} \\
& \mathrm{CoC}_{2} \mathrm{O}_{4}^{+} \rightarrow \mathrm{Co}^{2+}+\mathrm{C}_{2} \mathrm{O}_{4}^{-} \\
& \mathrm{C}_{2} \mathrm{O}_{4}^{-}+\mathrm{O}_{2}+\mathrm{O}_{3}+\mathrm{OH}^{-} \rightarrow \mathrm{CO}_{2}+\mathrm{O}_{2}^{-}+\mathrm{O}_{3}^{-}+\mathrm{OH}^{-}
\end{aligned}
$$

Foi observado que a remoção de oxalato aumentou com o decréscimo do $\mathrm{pH}$ de 6,7 para 5,3. Este resultado foi muito importante para a elucidação do mecanismo, pois evidencia uma rota distinta das observadas normalmente nos processos de ozonização, em que com a diminuição do valor de pH (e, conseqüentemente, diminuição da concentração de íons hidroxila que iniciam o processo de decomposição do ozônio e levam a formação de radicais hidroxila) observa-se uma menor taxa de remoção da matéria orgânica. Além disso, os autores utilizaram uma espécie seqüestradora de radicais hidroxila e não observaram nenhuma mudança na taxa de degradação do ácido oxálico. Tais indícios mostraram que a reação direta do ozônio com o complexo Co(II)-oxalato é a responsável pela degradação do ácido oxálico ${ }^{41,50}$.

O mecanismo do processo de ozonização catalítica ainda não está completamente estabelecido e pode variar em função do tipo de espécie metálica 
empregada, pH, composto-alvo, matriz, etc. Dentre estas variáveis, o estudo de diferentes metais de transição tem recebido grande destaque $26,41,44,47$. Vários metais foram estudados por diferentes grupos de pesquisa, sendo que, mais uma vez, a eficiência destas espécies depende de vários fatores experimentais ${ }^{44,47}$. Entretanto, o consumo de ozônio, a toxicidade do metal, possibilidade de reaproveitamento e custo também devem ser consideradas na avaliação do processo. $\mathrm{Ni}$ e colaboradores ${ }^{44}$ estudaram o incremento na degradação de uma solução de 2-clorofenol pela adição de vários tipos de íons metálicos durante a ozonização deste composto. $\mathrm{Pb}^{2+}, \mathrm{Cu}^{2+}, \mathrm{Zn}^{2+}, \mathrm{Fe}^{2+}, \mathrm{Ti}^{2+}$ e $\mathrm{Mn}^{2+}$ foram avaliados, sendo encontrado que a velocidade da reação de oxidação do composto organoclorado aumentou em todos os casos. Entretanto, o melhor resultado obtido levando-se em consideração a taxa de mineralização, foi observado empregando-se manganês, seguido pelo ferro e titânio. Em pH 3 e com $1 \mathrm{mg} \mathrm{L}^{-1}$ de $\mathrm{Mn}^{2+}$, a velocidade da reação de oxidação do 2-clorofenol aumentou três vezes e houve um aumento de $12,6 \%$ para $98 \%$, em apenas 60 minutos de tratamento, na remoção de carbono orgânico total. Comparando os resultados dos testes com diferentes íons metálicos, foi encontrado que o efeito catalítico em sistemas contendo íons $\mathrm{Pb}^{2+}, \mathrm{Cu}^{2+}$ e $\mathrm{Zn}^{2+}$ não era tão evidente. A avaliação da capacidade catalítica (aumento da eficiência de degradação do 2-clorofenol) dos 6 íons metálicos apresentou a seguinte ordem: $\mathrm{O}_{3}$ sozinho $<\mathrm{Pb}^{2+} \approx \mathrm{Cu}^{2+} \approx \mathrm{Zn}^{2+}<\mathrm{Fe}^{2+} \approx$ $\mathrm{Ti}^{2+}<\mathrm{Mn}^{2+}$

De um modo geral, vários trabalhos têm apresentado o manganês como uma das espécies mais promissoras para o processo de ozonização catalítica ${ }^{51-54}$. Ma e Graham ${ }^{54}$ mostraram que uma pequena quantidade de manganês melhora a 
degradação de pesticidas via reação com ozônio. Neste trabalho, os autores observaram que a redução da concentração de atrazina obtida com o processo de ozonização catalítica (na presença de $0,5 \mathrm{mg} \mathrm{L}^{-1}$ de $\mathrm{Mn}^{2+}$ ) em apenas 0,5 minuto é maior do que a alcançada com o ozônio sozinho em 2 minutos. A eficiência de transferência de ozônio para a água também foi maior com o aumento das doses de $\mathrm{Mn}(\mathrm{II})$, observando-se uma relação aproximadamente linear. Os autores também relatam que o dióxido de manganês formado in situ, via reação entre o ozônio e Mn(II), pode ter um papel importante na decomposição de ozônio e destruição catalítica da atrazina.

Mesmo apresentando resultados promissores na mineralização de matéria orgânica, o uso de metais pesados no tratamento de água pode não ser recomendável devido à natureza tóxica que estes metais apresentam e, além disso, também se deve levar em consideração o fator econômico, pois estes metais são relativamente caros e podem ser perdidos durante as etapas de reação ou exigir etapas laboriosas para sua remoção/recuperação. Devido a estes fatores, vários estudos estão sendo realizados buscando-se usar metais suportados em, por exemplo, alumina e sílica ${ }^{55,56}$.

Beltrán e colaboradores ${ }^{57}$ fizeram um estudo mostrando a eficiência do cobalto em solução e imobilizado sobre $\mathrm{Al}_{2} \mathrm{O}_{3}$. Os resultados apresentados para o metal suportado foram bastante promissores, nesta situação observou-se uma total mineralização do ácido oxálico. O estudo de metais de transição na forma heterogênea (suportes/sítios ativos heterogêneos) está sendo avaliado por diferentes grupos de pesquisa ${ }^{25,42,43}$ e será discutido no próximo tópico. 


\subsection{Ozonização catalítica heterogênea}

$\mathrm{Na}$ ozonização catalítica heterogênea, os principais catalisadores propostos são óxidos metálicos tais como: $\mathrm{MnO}_{2}, \mathrm{TiO}_{2}, \mathrm{Al}_{2} \mathrm{O}_{3}$ ou também metais ou óxidos metálicos em suportes de óxidos metálicos (por exemplo: $\mathrm{Cu}-\mathrm{Al}_{2} \mathrm{O}_{3}, \mathrm{Cu}$ $\mathrm{TiO}_{2}$, Ru-CeO 2 , V-O/TiO 2 , V-O/sílica gel e $\mathrm{TiO}_{2} / \mathrm{Al}_{2} \mathrm{O}_{3}, \mathrm{Fe}_{2} \mathrm{O}_{3} / \mathrm{Al}_{2} \mathrm{O}_{3}$ ). A atividade depurativa é baseada na decomposição catalítica do ozônio visando aumentar a geração de radicais hidroxila. A eficiência da ozonização catalítica depende da quantidade do catalisador, das propriedades da superfície e também do $\mathrm{pH}$ da solução. Neste tipo de oxidação, o catalisador parece ter duas funções: a) a presença da superfície heterogênea aumenta a dissolução do ozônio e b) o catalisador também age como iniciador para a reação de decomposição do ozônio ${ }^{25}$.

Vale ressaltar que as reações acontecem tanto na solução como na superfície do catalisador. As reações na superfície devem envolver várias etapas, tais como adsorção, reação de decomposição do ozônio, reações superficiais de oxidação e processos de dessorção.

Existem basicamente três mecanismos possíveis para a ozonização catalítica em sistemas heterogêneos:

a) adsorção do ozônio na superfície do catalisador levando à formação de espécies ativas que reagem com moléculas orgânicas não adsorvidas;

b) adsorção da matéria orgânica na superfície do catalisador e sua posterior reação com o ozônio dissolvido; 
c) adsorção de ambos, o ozônio e a molécula orgânica e a sua posterior interação (Figura 4);

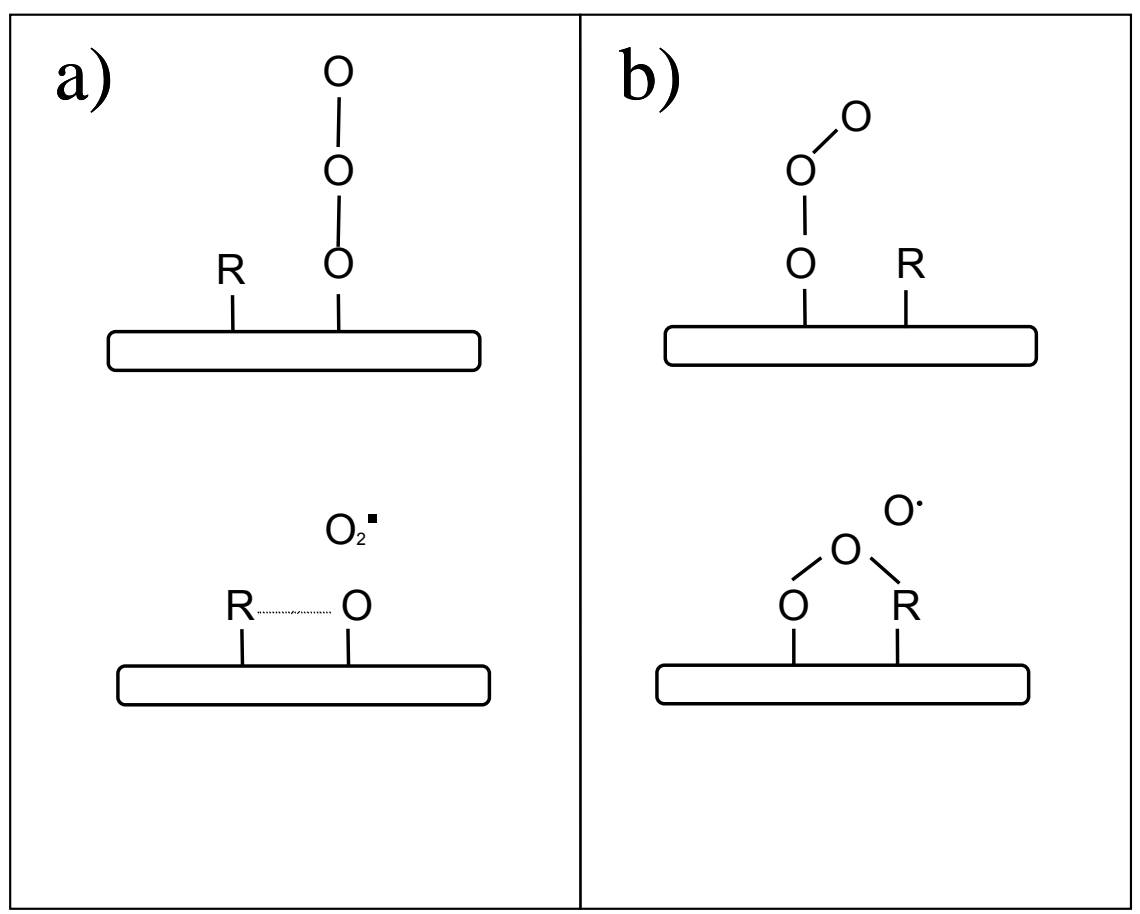

Figura 4. Diferentes formas de interação do ozônio com a matéria orgânica adsorvida na superfície do metal, formação de $\mathrm{O}_{2}$ (a) e formação de $O$ (b).

Vários óxidos metálicos, especialmente alumina, titânia e sílica são utilizados como superfície ativa para o processo de ozonização catalítica heterogênea. Estes óxidos são os mais empregados principalmente devido as suas características físicas (área superficial; densidade; volume, quantidade e tamanho de poro; resistência mecânica, etc.) e químicas (estabilidade e presença de sítios ativos na superfície, principalmente sítios ácidos de Lewis).

Um dos principais parâmetros que determinam a propriedade catalítica do óxido utilizado é a acidez ou basicidade de sua superfície. Grupos hidroxila estão 
presentes em todas as superfícies de óxidos metálicos, entretanto a quantidade e propriedade destes grupos dependem da natureza do óxido ${ }^{58}$. Bulanin e colaboradores $^{59}$ concluíram que a adsorção de ozônio sobre a superfície de óxidos do tipo $n$ resulta na produção de oxigênio e/ou oxidação da superfície. Já a interação do ozônio com óxidos do tipo $p$ leva à decomposição do ozônio via a formação de espécies radicalares, principalmente, o ânion radical superóxido. Comportamento semelhante foi observado variando-se o $\mathrm{pH}$ do meio reacional, conforme mostram as equações 25 a 31 ( $\mathrm{S}$ = sítio ativo da superfície do óxido metálico $)^{25}$.

$\underline{\text { reações na superfície em meio ácido }}$

$$
\begin{aligned}
& \mathrm{O}_{3}+\mathrm{S} \rightleftarrows \mathrm{O}_{3}-\mathrm{S} \\
& \mathrm{O}_{3}-\mathrm{S} \rightleftarrows \mathrm{O}-\mathrm{S}+\mathrm{O}_{2} \\
& \mathrm{O}_{3}+\mathrm{O}-\mathrm{S} \rightleftarrows 2 \mathrm{O}_{2}+\mathrm{S}
\end{aligned}
$$

reações na superfície em meio básico

$$
\begin{aligned}
& \mathrm{OH}^{-}+\mathrm{S} \rightleftarrows \mathrm{OH}-\mathrm{S} \\
& \mathrm{O}_{3}+\mathrm{OH}-\mathrm{S} \rightleftarrows \mathrm{O}_{3}-\mathrm{S}+\mathrm{HO} \\
& \mathrm{O}_{3}-\mathrm{S} \rightleftarrows \mathrm{O}-\mathrm{S}+\mathrm{O}_{2} \\
& \mathrm{O}_{3}+\mathrm{O}-\mathrm{S} \rightleftarrows \mathrm{O}_{2} \cdot+\mathrm{S}+\mathrm{O}_{2}
\end{aligned}
$$

A alumina tem se mostrado bastante efetiva para catalisar a oxidação de compostos orgânicos poluentes pelo ozônio. $\mathrm{Ni}$ e $\mathrm{Chen}^{60}$ estudando a degradação de 2-clorofenol por $\mathrm{O}_{3}$ e $\mathrm{O}_{3} / \mathrm{Al}_{2} \mathrm{O}_{3}$ observaram um aumento na redução do teor COT de aproximadamente $84 \%$ quando empregaram a alumina. O mecanismo 
proposto neste caso consiste na adsorção simultânea do ozônio e da molécula orgânica na superfície do catalisador. A decomposição do ozônio ocorre nos sítios metálicos produzindo radicais $\mathrm{O}$ - ligados que são mais reativos do que o ozônio e este, por conseqüência, oxida moléculas orgânicas adjacentes. O radical ânion Oé continuamente gerado pelo ozônio dissolvido e é transferido para a superfície do catalisador. A afinidade dos produtos oxidados pelo catalisador decresce e os produtos finais de oxidação dessorvem da superfície do catalisador ${ }^{61}$.

As sílicas mesoporosas ordenadas (SMO) também têm despertado interesse para serem aplicadas como suporte em reações catalíticas heterogêneas, principalmente em virtude de suas características peculiares, tais como: áreas superficiais altas, tamanhos de poros grandes altamente ordenados (até $30 \mathrm{~nm}$ ), além de serem estáveis térmica e hidrotermicamente. As SMO podem ser preparadas a partir de vários métodos sintéticos e dependendo do direcionador de estrutura utilizado, podem-se obter sílicas com diferentes tamanhos de poros e geometria de ordenação. Além disso, sua superfície pode ser modificada utilizando diferentes agentes sililantes e também, pela incorporação de metais na sua estrutura ${ }^{62-66}$.

A incorporação de metais nas SMO pode produzir materiais com propriedades excelentes para catálise, inclusive para reações de interesse ambiental ${ }^{67}$. Dentre esses metais, o ferro e o manganês têm atraído considerável atenção devido as suas altas atividades como catalisador em uma série de reações.

Além da utilização de óxidos metálicos de transição em suspensão, há vários estudos relatando o emprego de $\mathrm{TiO}_{2}, \mathrm{MnO}_{2}, \mathrm{Fe}_{2} \mathrm{O}_{3}$ e outros óxidos 
imobilizados sobre suportes, tais como: sílica gel (argila, alumina, etc) ${ }^{55,56,68-75}$. Além da natureza dos óxidos e de suas características superficiais, as propriedades catalíticas destes sistemas também dependerão fortemente do método de preparação (síntese e tratamentos térmicos e químicos). 


\section{OBJETIVOS}

O objetivo principal deste trabalho foi buscar formas de aumentar a eficiência do processo de ozonização sobre a mineralização de compostos orgânicos poluentes, principalmente de corantes utilizados pela indústria têxtil. Neste sentido, buscou-se avaliar o emprego do processo de ozonização catalítica tanto homogênea quanto heterogênea.

\subsection{Objetivos específicos}

Os objetivos específicos deste trabalho foram:

- montar e desenvolver um sistema de ozonização avaliando a influência de parâmetros como vazão do oxigênio e potencial aplicado na quantidade de ozônio produzido;

- estudar a degradação e mineralização de uma solução $100 \mathrm{mg} \mathrm{L}^{-1}$ do corante modelo pertencente à classe dos azocorantes (Preto Remazol B) verificando o efeito (i) do pH do meio reacional no mecanismo de ação do ozônio; (ii) da adição de peróxido de hidrogênio, de íons metálicos $\left(\mathrm{Fe}^{3+}\right.$ e $\left.\mathrm{Mn}^{2+}\right)$ e de metais suportados na taxa e no grau de mineralização.

- aplicar os melhores resultados no tratamento de outras classes de corantes (antraquinona e ftalocianina, normalmente muito utilizadas pela indústria têxtil) e em um efluente real oriundo de uma indústria têxtil. 


\section{PARTE EXPERIMENTAL}

\subsection{Reagentes}

$\mathrm{HCl}, \mathrm{NaOH}, \mathrm{KI}, \mathrm{Na}_{2} \mathrm{~S}_{2} \mathrm{O}_{3}, \mathrm{H}_{2} \mathrm{O}_{2}(30 \% \mathrm{v} / \mathrm{v}), \mathrm{MnSO}_{4} \cdot \mathrm{H}_{2} \mathrm{O}, \mathrm{FeSO}_{4} \cdot 7 \mathrm{H}_{2} \mathrm{O}$, $\mathrm{Fe}_{2}\left(\mathrm{SO}_{4}\right)_{3} \cdot 9 \mathrm{H}_{2} \mathrm{O}, \mathrm{MnO}_{2}, \mathrm{FeCl}_{3} \cdot \mathrm{xH}_{2} \mathrm{O}, \mathrm{MnCl}_{2} \cdot 4 \mathrm{H}_{2} \mathrm{O}$, tetraetilortossilicato (TEOS), amido, tolueno e etanol foram adquiridos da Merck e/ou Sigma-Aldrich. $\mathrm{O}_{2}$ $(99,9 \%), \mathrm{N}_{2}(99,9 \%)$ foram adquiridos da Air Products e o copolímero tribloco Vorasurf $^{\circledR} 504\left(\mathrm{EO}_{39} \mathrm{BO}_{47} \mathrm{EO}_{39}\right)$ foi adquirido da Dow Chemical Company. Os reagentes utilizados eram de alto grau de pureza (PA) e foram utilizados sem tratamento prévio. Soluções aquosas foram preparadas com água deionizada

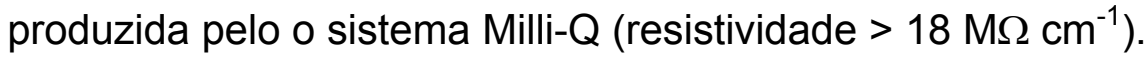

Os corantes empregados neste estudo (Tabela 2) foram cedidos pela empresa Dystar (Suzano/SP) e utilizados na forma de soluções aquosas com concentração de $100 \mathrm{mg} \mathrm{L}^{-1}$. Esses corantes representam uma grande parcela das principais classes de corantes utilizados pela indústria têxtil, sendo que suas estruturas químicas estão apresentadas na Figura 5.

Tabela 2. Descrição dos corantes avaliados neste estudo.

\begin{tabular}{|c|ccc|}
\hline Corante & Grupo & Color Index & Abs $_{\text {max }}$ (nm) \\
& Funcional & & \\
\hline Preto Remazol B & Azo & 20505 & 600 \\
Azul Remazol Brilhante RN & Antraquinona & 61200 & 593 \\
Turquesa Remazol G 133 & Ftalocianina & 74160 & 625 \\
\hline
\end{tabular}



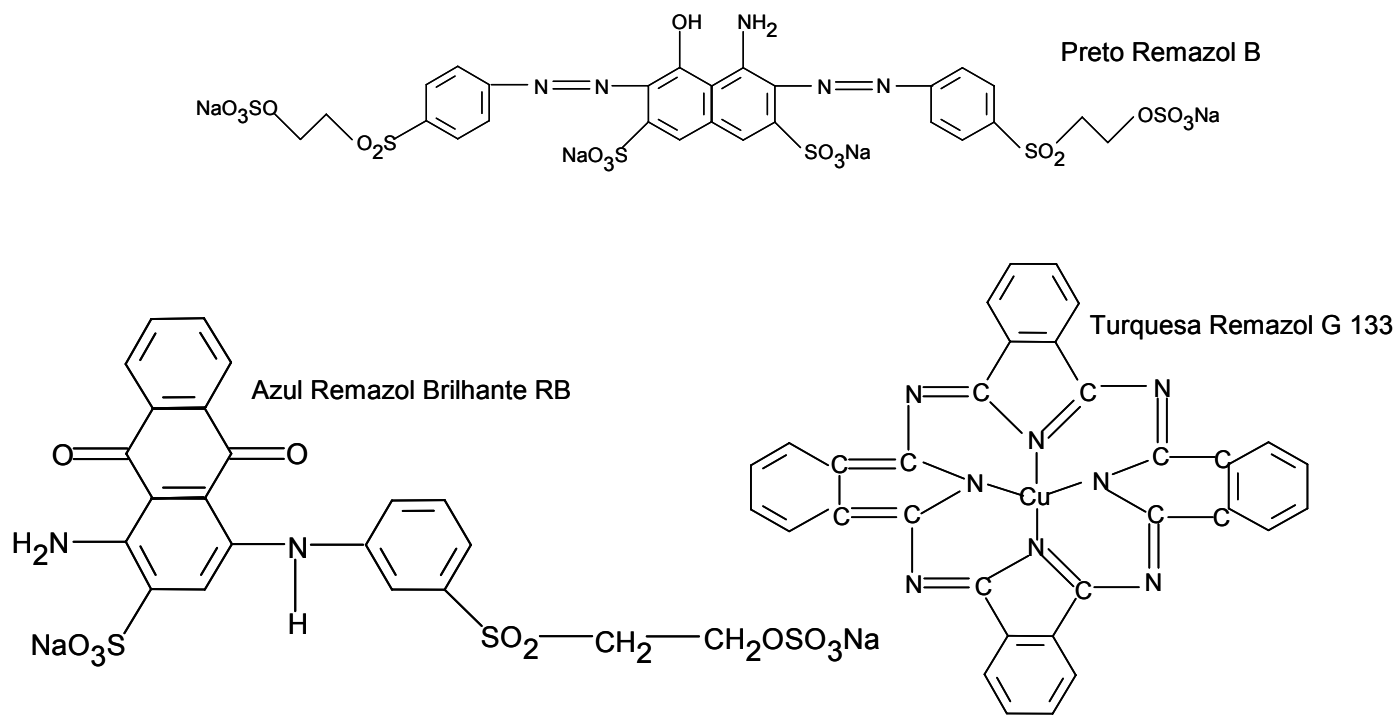

Figura 5. Estruturas químicas dos corantes utilizados neste estudo.

O efluente estudado foi coletado na indústria têxtil Carnatiba (Santa Barbara d'Oeste/SP). A amostragem foi realizada antes da entrada da estação de tratamento de efluentes (ETE) da empresa; posteriormente a amostra foi estocada a $4{ }^{\circ} \mathrm{C}$. As características iniciais deste efluente são apresentadas na Tabela 3.

Tabela 3. Características iniciais do efluente da indústria têxtil.

\begin{tabular}{|c|ccc|}
\hline Coloração & pH & DQO & COT \\
\hline azul $\left(\lambda_{\max }=668 \mathrm{~nm}\right)$ & 6,5 & $2.234 \mathrm{mgo}_{\mathrm{O}} \mathrm{L}^{-1}$ & $842 \mathrm{mg} \mathrm{L}^{-1}$ \\
\hline
\end{tabular}

O ozônio foi produzido in situ segundo a montagem apresentada na Figura 6. 


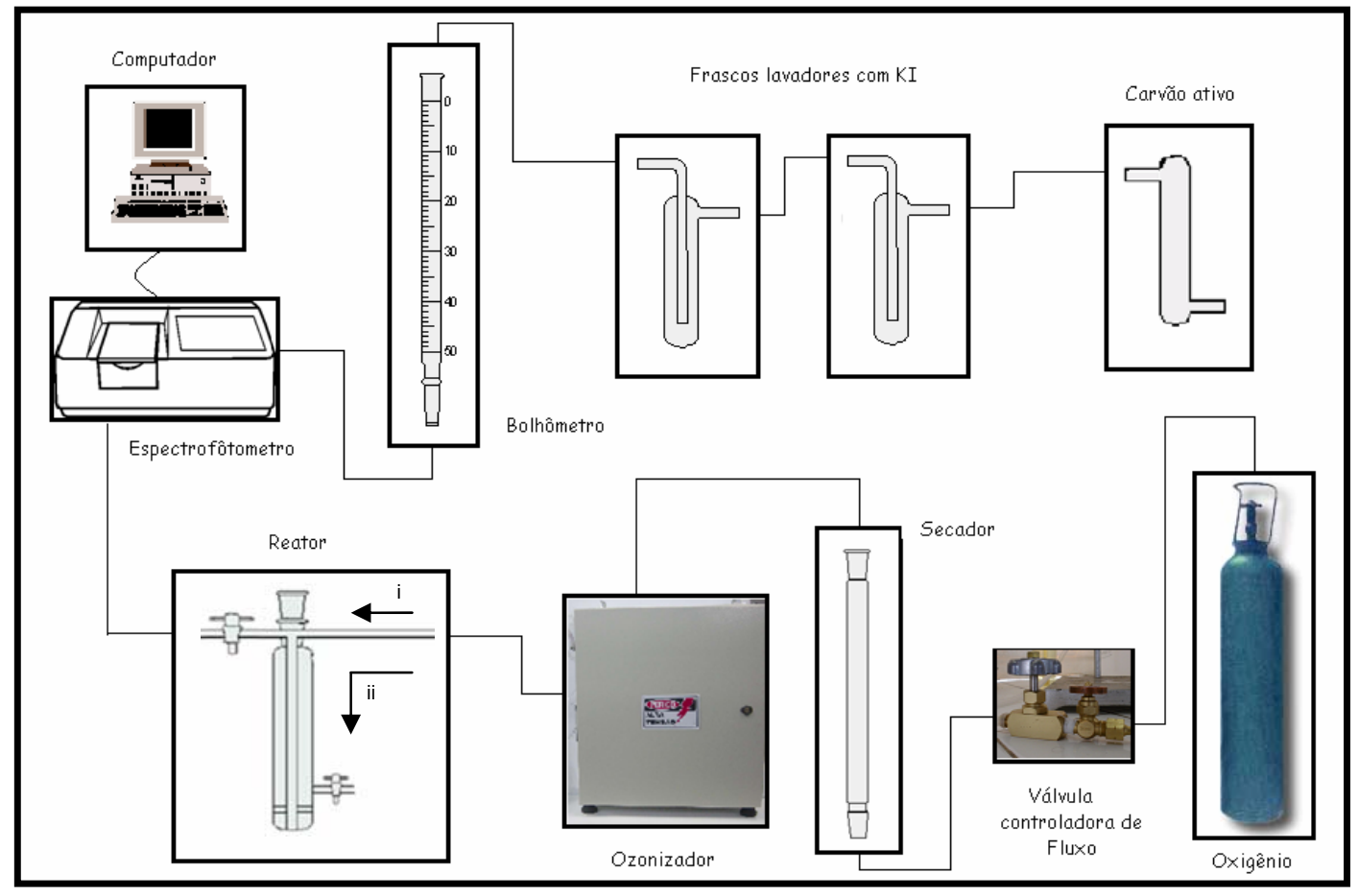

Figura 6. Sistema de geração de ozônio.

No sistema de geração de ozônio utilizou-se um gerador de ozônio da marca Multivácuo (MV 06) baseado no método de descarga por efeito corona (discutido no item 4.1.1), onde se empregou oxigênio 99,9\% como gás de alimentação do sistema. A vazão da mistura gasosa foi controlada por um sistema de válvulas agulha. $\mathrm{O}$ reator, no qual as espécies alvo interagiam com $\circ \mathrm{O}_{3}$, possuía uma capacidade de $500 \mathrm{~mL}$ de amostra (soluções de corante/efluente). Este foi confeccionado em formato tubular, com uma razão altura/diâmetro interno de aproximadamente 5, ou seja, o reator era mais comprido do que largo visando aumentar o tempo de contato entre ozônio e a solução a ser degradada. A entrada do gás foi feita pela parte inferior do reator, passando por uma placa porosa de vidro sinterizado, para melhorar a transferência de massa do ozônio da fase gasosa para a fase líquida. 
O ozônio foi determinado espectrofotometricamente a $258 \mathrm{~nm}$ $\left(\varepsilon=3000 \mathrm{~L} \mathrm{~mol}^{-1} \mathrm{~cm}^{-1}\right.$ ), utilizando-se um espectrofotômetro da marca Shimadzu (Multi Spec-1501) $^{76}$. A mistura gasosa contendo oxigênio e ozônio, após sair do reator, passava através de uma célula de fluxo que apresenta um caminho óptico de $1 \mathrm{~cm}$ localizada no interior do espectrofotômetro, sendo então determinada a absorbância. Esta metodologia foi aplicada em todas as determinações de concentração de ozônio, exceto quando especificamente mencionado.

O ozônio residual do sistema foi destruído pela passagem do gás por um frasco lavador contendo iodeto de potássio e depois por um frasco contendo carvão ativo para garantir a não liberação de ozônio residual no ambiente laboratorial.

\subsection{Controle analítico}

A porcentagem de redução nos parâmetros de avaliação (descoloração e mineralização) foi determinada comparando-se as amostras das soluções de corantes ou do efluente após diferentes tempos de tratamento com soluções nas mesmas condições inicias (por exemplo: pH e concentração), sendo assim, temse que a \% redução $=\mathrm{C} / \mathrm{C}_{0} \times 100$, onde $\mathrm{C}=$ concentração do corante no tempo em estudo e $\mathrm{C}_{0}=$ concentração inicial do corante antes do tratamento.

\subsubsection{Determinação da degradação dos grupos cromóforos (descoloração)}

O acompanhamento da degradação do corante foi avaliado usando um espectrofotômetro UV-Vis modelo Cary 50 Probe da marca Varian. A análise se baseou na absorção da radiação do grupo cromóforo em determinadas faixas de 
comprimento de onda. Foi feito o acompanhamento da diminuição destas bandas de absorção no decorrer do tempo de tratamento nas diferentes condições.

\subsubsection{Determinação da mineralização}

A quantificação da mineralização, ou seja, a completa oxidação da matéria orgânica em dióxido de carbono, água e ácidos inorgânicos, foi avaliada por meio da medida da concentração de carbono orgânico total (COT) seguindo o método padrão 5310 B do Standard Methods for the Examination of Water and Wastewater, 20th Edition ${ }^{77}$. A técnica é baseada na oxidação da matéria orgânica pela introdução da amostra numa câmara de reação aquecida a uma temperatura de aproximadamente $680^{\circ} \mathrm{C}$, empregando-se um catalisador de platina adsorvido sobre óxido de alumínio. Dessa forma, a água é vaporizada e o carbono do analito é transformado em $\mathrm{CO}_{2}$, sendo posteriormente quantificado por um analisador de infravermelho não dispersivo. $O$ carbono inorgânico é medido utilizando-se uma câmara de reação que contém ácido fosfórico, que permite sua transformação em $\mathrm{CO}_{2}$, o qual é quantificado da mesma forma descrita anteriormente. Em todos os experimentos foi utilizado um analisador de COT da marca Shimadzu (modelo TOC - 5000A).

\subsubsection{Determinação do pH}

As medidas de $\mathrm{pH}$ foram feitas no aparelho Marconi PA 200, utilizando um eletrodo de vidro combinado. Foram feitas medidas do $\mathrm{pH}$, ao decorrer do experimento, das diferentes amostras coletadas. 


\subsubsection{Determinação de demanda química de oxigênio (DQO)}

A DQO foi determinada utilizando-se o método 5220 D do Standard Methods for the Examination of Water and Wastewater, 20th Edition ${ }^{77}$. Neste método, a amostra é digerida em vaso fechado pela ação de um forte agente oxidante, geralmente o dicromato de potássio (em meio com ácido sulfúrico), por um período de duas horas. A redução do $\mathrm{Cr}^{6+}$ para $\mathrm{Cr}^{3+}$, durante o processo de oxidação do analito, proporciona uma forte absorção no comprimento de onda de $600 \mathrm{~nm}$. A variação na absorção da radiação visível neste comprimento de onda é utilizada para quantificar espectroscopicamente a DQO. A correlação entre a concentração de $\mathrm{Cr}^{3+}$ e a quantidade de matéria orgânica é realizada empregando-se a oxidação de biftalato de potássio como padrão. A quantidade de oxidante consumido é expressa em equivalência de oxigênio $\left(\mathrm{mgo}^{\mathrm{L}} \mathrm{L}^{-1}\right)$.

\subsection{Método iodométrico para o cálculo da constante de transferência de massa}

Nos experimentos de determinação de $\mathrm{K}_{\mathrm{L}} \mathrm{a}$, utilizou-se água deionizada com o $\mathrm{pH}$ ajustado para 3 .

Ao longo da ozonização, colheram-se alíquotas de $3 \mathrm{~mL}$ da amostra. Estas alíquotas foram armazenadas em frascos contendo igual quantidade de solução de $\mathrm{KI}$ 1\% (m/m). O ozônio solubilizado na alíquota oxidou o iodeto a iodo.

Posteriormente, realizou-se a titulação iodométrica ${ }^{78}$ do conteúdo dos frascos com uma solução de tiossulfato de sódio $1,00 \times 10^{-4} \mathrm{~mol} \mathrm{~L}^{-1}$ utilizando $0,5 \mathrm{~mL}$ de solução de amido $2,5 \%$ como indicador. Inicialmente a coloração da 
solução era roxo escuro, sendo a viragem detectada pelo aparecimento de uma cor rosa claro.

\subsection{Cinética de degradação}

Em todos os ensaios realizados utilizou-se um volume de solução de $350 \mathrm{~mL}$, o que representava $80 \%$ do volume total do reator. Este volume foi usado para garantir uma melhor eficiência do sistema, impedindo também que houvesse problemas de perda de material contido no reator devido ao borbulhamento do sistema durante a injeção do gás.

Após adicionar a solução no reator e fechar o sistema, permitiu-se a entrada do gás oxigênio no mesmo, mas sem deixar interagir com a solução (caminho i no Reator da Figura 6). Ajustou-se a voltagem aplicada no ozonizador e ligou-se o mesmo. Esperaram-se 10 minutos para a estabilização da produção do ozônio (dado acompanhado espectrofometricamente) e antes de permitir a interação do fluxo gasoso com a solução (caminho ii do Reator da Figura 6) coletou-se uma amostra. A não ser quando especificamente mencionado, foram coletadas alíquotas de $10 \mathrm{~mL}$ após $2,5,10,15$ e 30 minutos de ozonização e todos os ensaios foram realizados em duplicatas.

\subsection{Síntese do material suporte para o processo de ozonização catalítica heterogênea}

A síntese das sílicas mesoestruturadas foi realizada em colaboração com o grupo do Prof. Dr. Jivaldo Matos do $\mathrm{IQ} / \mathrm{USP}^{67}$, sendo as principais etapas descritas sucintamente a seguir. 


\subsubsection{Sílica Mesoporosa Ordenada (SMO)}

A SMO de estrutura cúbica do tipo FDU-1 foi preparada em meio ácido, utilizando como fonte de sílica o TEOS e como agente direcionador de estrutura o copolímero tribloco Vorasurf $^{\circledR} 504$. A mistura obtida foi transferida para um frasco de Teflon $^{\circledR}$ e levada para uma estufa a $100^{\circ} \mathrm{C}$ por 12 h. O produto sólido obtido foi isolado por filtração, lavado várias vezes com água destilada e secado à temperatura ambiente. O sólido resultante foi levado a um forno tubular e calcinado em atmosfera dinâmica de $\mathrm{N}_{2}$ com uma vazão de $100 \mathrm{~mL} \mathrm{~min}^{-1}$ e razão de aquecimento de $2{ }^{\circ} \mathrm{C} \min ^{-1}$ até $540{ }^{\circ} \mathrm{C}$ e nesta temperatura foi mantido sob atmosfera de ar por $600 \mathrm{~min}$.

\subsection{2. $\mathrm{SMO}-\mathrm{Fe}_{2} \mathrm{O}_{3}$}

A incorporação do ferro ocorreu durante a síntese da SMO, utilizando $\mathrm{FeCl}_{3} .3 \mathrm{H}_{2} \mathrm{O}(5 \%$ em mol de $\mathrm{Fe}$ ) e tetraetilortossilicato (TEOS) como fonte de ferro e sílica, respectivamente, e o copolímero tribloco Vorasurf ${ }^{\circledR}$ como direcionador de estrutura. Após o tratamento hidrotérmico, o material foi dividido em partes iguais, sendo uma parte filtrada (A1) e a outra colocada em banho-maria (A2) para eliminação do solvente. O material após secagem foi calcinado em $\mathrm{N}_{2}$ até $540{ }^{\circ} \mathrm{C}$ e isoterma de 200 minutos em ar para eliminar o material carbonácio.

\subsection{3. $\mathrm{SMO}-\mathrm{MnO}_{2}$}

A incorporação do manganês a SMO de estrutura cúbica tipo FDU-1 foi realizada por dois métodos: incorporação e modificação superficial. 


\subsubsection{Incorporação}

O copolímero tribloco Vorasurf ${ }^{\circledR} 504$ foi solubilizado em etanol, adicionado à solução de $\mathrm{HCl}$ e o sistema foi mantido sob agitação magnética até obtenção de uma solução homogênea. Em seguida, o TEOS foi adicionado e o sistema foi mantido sob agitação mecânica e magnética com posterior adição do $\mathrm{MnCl}_{2} \cdot 4 \mathrm{H}_{2} \mathrm{O}$ $\left(\sim 2,5\right.$ e $5 \%$ em mol do íon $\left.\mathrm{Mn}^{2+}\right)$. O produto sólido, obtido por evaporação da solução, foi calcinado sob atmosfera dinâmica de $\mathrm{N}_{2}$ com uma vazão de $100 \mathrm{~mL} \mathrm{~min}^{-1}$ e razão de aquecimento de $2{ }^{\circ} \mathrm{C} \min ^{-1}$ até $540{ }^{\circ} \mathrm{C}$ e, nesta temperatura, foi mantido sob atmosfera de ar por $600 \mathrm{~min}$.

\subsubsection{Modificação superficial}

A sílica mesoporosa foi ativada a $200{ }^{\circ} \mathrm{C}$ e suspensa em tolueno. A esta suspensão foi adicionado $\mathrm{MnCl}_{2} \cdot 4 \mathrm{H}_{2} \mathrm{O}\left(\sim\right.$ 1,5; 2,5; 3,5 e $5 \%$ em mol de $\left.\mathrm{Mn}^{2+}\right)$ solubilizado em etanol. O sistema foi mantido sob agitação por 48 h, em seguida, foi filtrado e lavado com tolueno. $\mathrm{O}$ sólido obtido foi calcinado a $540{ }^{\circ} \mathrm{C}$, sob atmosfera de ar utilizando razão de aquecimento de $2^{\circ} \mathrm{C} \min ^{-1}$. 


\section{RESULTADOS E DISCUSSÕES}

\subsection{Sistema de ozonização}

\subsubsection{Produção de ozônio}

Tal como descrito no item 3.1, o ozônio é uma molécula instável, o que impede a sua armazenagem. Desta forma, há a necessidade de sua geração in situ, para tanto se empregou um gerador de ozônio baseado no método de descarga elétrica por efeito corona. De uma maneira simplificada, este processo é baseado na aplicação de uma diferença de potencial entre dois eletrodos (geralmente feitos com aço inoxidável), pelos quais força-se a passagem de um fluxo de ar seco ou oxigênio (Figura 7). Como resultado da descarga elétrica, moléculas do gás oxigênio são decompostas em $\mathrm{O}$; o qual se combina com outras moléculas de $\mathrm{O}_{2}$, promovendo a formação de $\mathrm{O}_{3}{ }^{14}$ :

$$
\begin{aligned}
& \mathrm{O}_{2} \rightarrow \mathrm{O}+\mathrm{O} \\
& \mathrm{O}+\mathrm{O}_{2} \rightarrow \mathrm{O}_{3}
\end{aligned}
$$

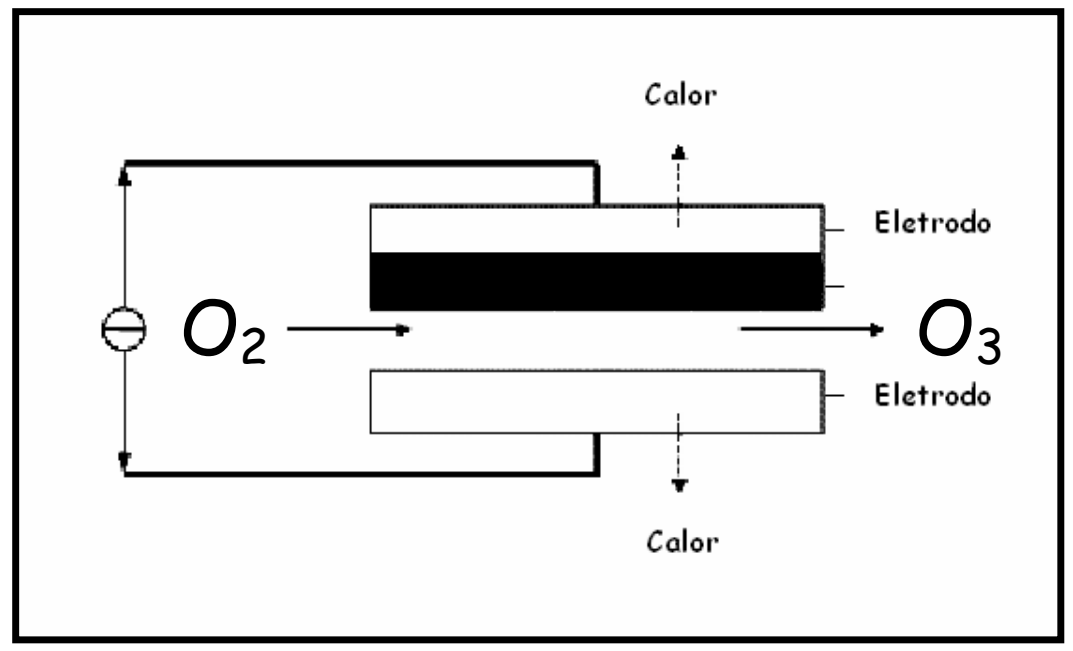

Figura 7. Esquema simplificado do princípio de funcionamento do sistema de geração de ozônio baseado no método de descarga por efeito corona. 
Vários parâmetros experimentais podem afetar a taxa de conversão de $\mathrm{O}_{2}$ em $\mathrm{O}_{3}$, sendo que o rendimento deste processo varia entre $1-4 \%(\mathrm{~m} / \mathrm{m})$ e entre $4-14 \%(\mathrm{~m} / \mathrm{m})$ para sistemas alimentados com ar ou oxigênio, respectivamente ${ }^{71}$. No presente trabalho, o ozônio foi produzido a partir de $\mathrm{O}_{2}$ comercial com grau de pureza de 99,9\%. Além do tipo de gás de alimentação, dois outros parâmetros exercem grande influência sobre a quantidade de ozônio produzido: diferença de potencial aplicado nos eletrodos e vazão de entrada do gás (ar ou oxigênio).

O efeito do potencial aplicado entre os eletrodos do sistema gerador de ozônio sobre a produção deste gás é apresentado na Figura 8. Apesar do gerador permitir uma variação no potencial aplicado entre 0,5 e $10 \mathrm{kV}$, a influência deste parâmetro foi avaliada aplicando-se potenciais entre 4 e $8 \mathrm{kV}$. Tal faixa foi escolhida devido à constatação que, abaixo de $4 \mathrm{kV}$, não havia uma produção significativa de ozônio; enquanto que, para valores maiores que 8 kV, a produção de ozônio foi superior à capaz de ser detectada de maneira confiável pelo método de monitoramento de ozônio empregado ${ }^{76}$.

$\mathrm{Na}$ Figura 9 pode-se observar que há uma correlação linear entre a quantidade de ozônio produzido e a diferença de potencial aplicada nos eletrodos. $\mathrm{Na}$ faixa de potenciais estudada, observou-se um acréscimo de $8,9 \pm 0,4 \mathrm{mg} \mathrm{L}^{-1}$ na concentração de ozônio para cada incremento de $1 \mathrm{kV}$. Desta forma, a variação na magnitude do potencial aplicado permitiu uma ampla variação na quantidade de ozônio produzido. Por exemplo, utilizando-se uma vazão de $30 \mathrm{~L}_{\mathrm{O} 2} \mathrm{~h}^{-1}$, o sistema empregado foi capaz de produzir entre 70 e $1.120 \mathrm{mgo} \mathrm{h}^{-1}$. 


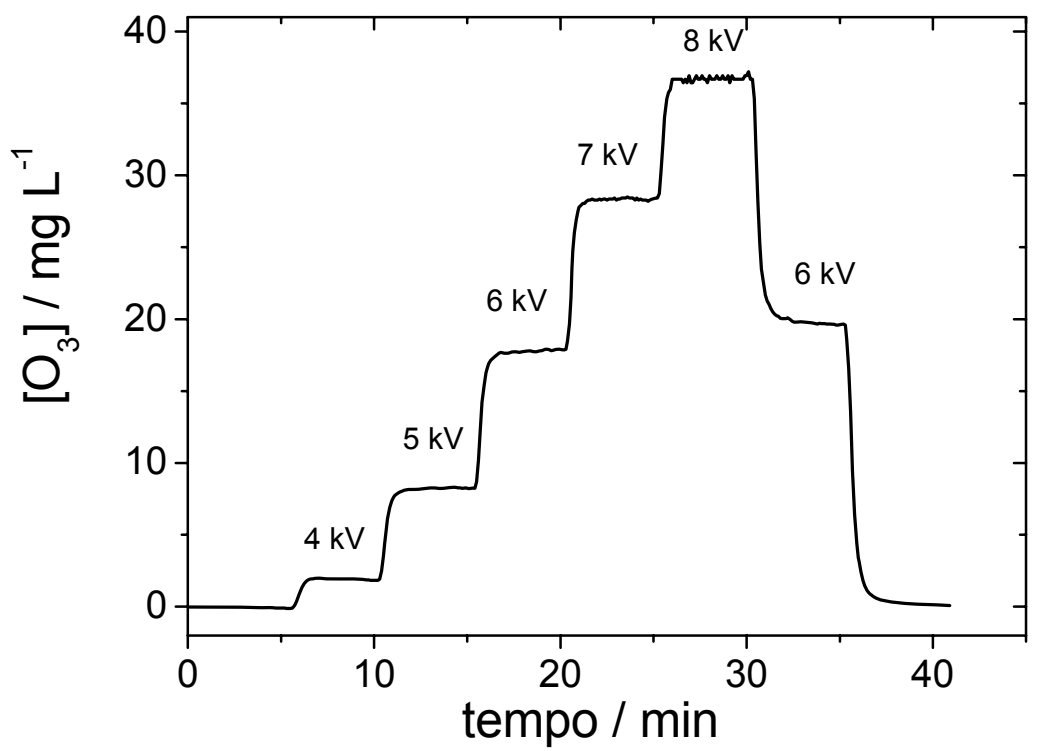

Figura 8. Perfil da produção de ozônio em função da diferença de potencial aplicada. Vazão de oxigênio: $30 \mathrm{~L} \mathrm{~h}^{-1}$.

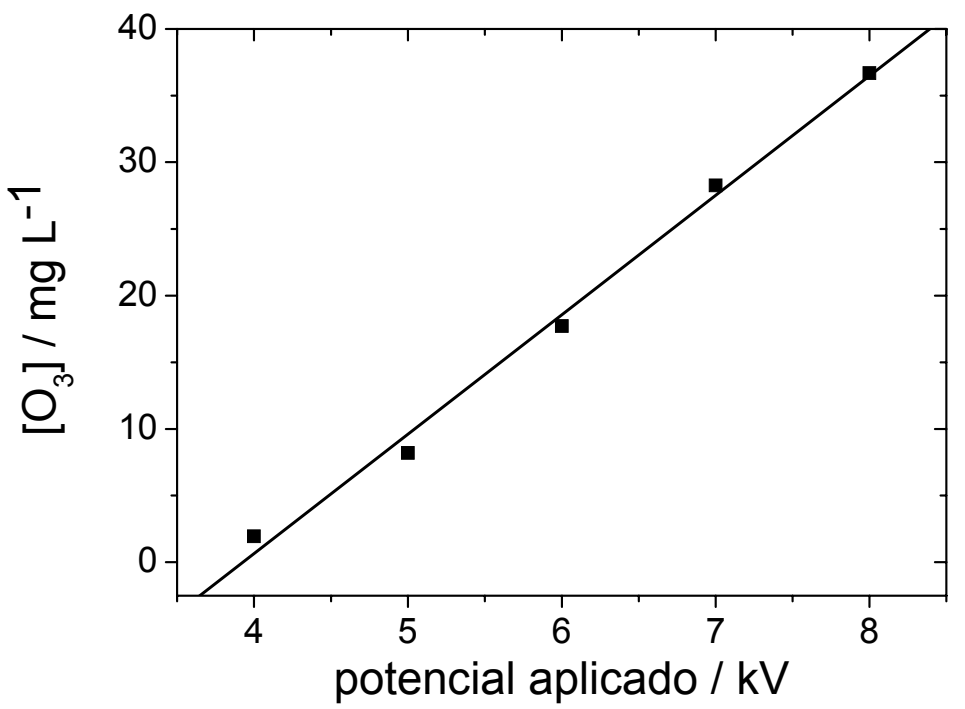

Figura 9. Produção de ozônio em função da diferença de potencial aplicada. Vazão de oxigênio: $30 \mathrm{~L} \mathrm{~h}^{-1}$. 
Uma outra forma de variar a quantidade de ozônio produzido pelo sistema ozonizador é alterando-se a vazão do gás de alimentação. A Figura 10a mostra uma relação linear entre a concentração de ozônio produzido e a vazão de entrada do $\mathrm{O}_{2}$. De um modo geral, devido a um efeito de diluição e ao menor tempo de residência do ozônio no sistema; quanto maior a vazão do gás de entrada, menor a concentração de ozônio (para uma diferença de potencial de 5 $k \mathrm{~V}$, observou-se uma variação de $(-0,24 \pm 0,07) \mathrm{mg}_{\circ} \mathrm{L}^{-1}$, por incrementos de $1 \mathrm{~L}$ $\mathrm{h}^{-1}$ na vazão de $\mathrm{O}_{2}$ ). Por outro lado, conforme pode ser observado na Figura $10 \mathrm{~b}$, a quantidade de ozônio produzido aumenta linearmente em função da vazão de $\mathrm{O}_{2}$, pois um aumento na vazão implica em uma maior quantidade de oxigênio para ser convertido em $\mathrm{O}_{3}$ (na condição mencionada acima, observou-se um aumento de 6,3 \pm 0,6 $\mathrm{mg} \mathrm{h}^{-1}$ para cada incremento de $1 \mathrm{~L} \mathrm{~h}^{-1}$ na vazão de $\mathrm{O}_{2}$ ).

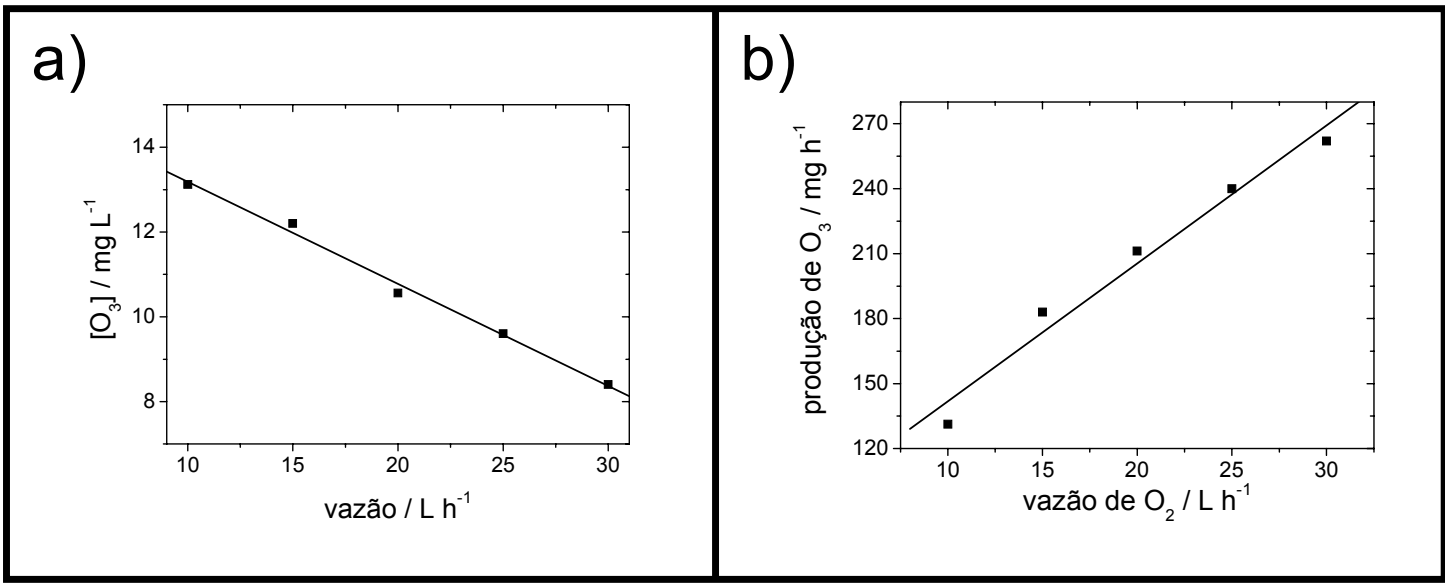

Figura 10. Concentração de ozônio (a) e quantidade de ozônio produzido (b) em diferentes vazões de entrada de $\mathrm{O}_{2}$. Potencial aplicado para a geração de ozônio: 5 kV. 
Desta forma, a quantidade de ozônio produzido pode ser controlada de maneira relativamente simples alterando-se a diferença de potencial aplicada nos eletrodos do sistema gerador e a vazão de entrada de $\mathrm{O}_{2}$. Após estes estudos preliminares, observou-se que a vazão de entrada do gás também possuía uma correlação com o tamanho das bolhas no reator. O tamanho destas bolhas, por sua vez, tem efeito sobre a transferência de massa entre as fases gasosa e líquida. De um modo geral, quanto menor o tamanho das bolhas, maior a eficiência na transferência de fase, permitindo que uma maior quantidade de ozônio possa estar disponível para interagir com o composto-alvo dissolvido na solução ${ }^{14}$.

Levando-se estes fatores em consideração, salvo quando explicitamente mencionado, todos os demais experimentos foram realizados empregando-se uma diferença de potencial de $5 \mathrm{kV}$ e vazão de entrada de $\mathrm{O}_{2}$ igual a $54 \mathrm{~L} \mathrm{~h}^{-1}$. Sob tais condições, o sistema permitiu a produção de 1.120 mg de ozônio por hora, com uma concentração de $20,8 \mathrm{mgoz}^{\mathrm{L}^{-1}}$ na fase gasosa.

\subsubsection{Transferência de massa no reator}

Devido a sua polaridade, o ozônio possui uma solubilidade em água maior que a do oxigênio (constante de Henry a $25{ }^{\circ} \mathrm{C}$ para o $\mathrm{O}_{3}=4,2 \times 10^{-2} \mathrm{~mol} \mathrm{~L}^{-1}$ atm ${ }^{-1}$ e para o $\left.\mathrm{O}_{2}=1,3 \times 10^{-3} \mathrm{~mol} \mathrm{~L}^{-1} \mathrm{~atm}^{-1}\right)^{15}$. Apesar disto, a transferência do ozônio da fase gasosa para a fase líquida é um processo limitante na utilização deste gás como agente oxidante. Vários modelos têm sido propostos para descrever a transferência do ozônio da fase gasosa para a líquida ${ }^{76}$. Geralmente, estes modelos postulam que a concentração em ambas as fases é homogênea, 
com exceção de uma delgada zona em torno da interface gás-líquido (Figura 11).

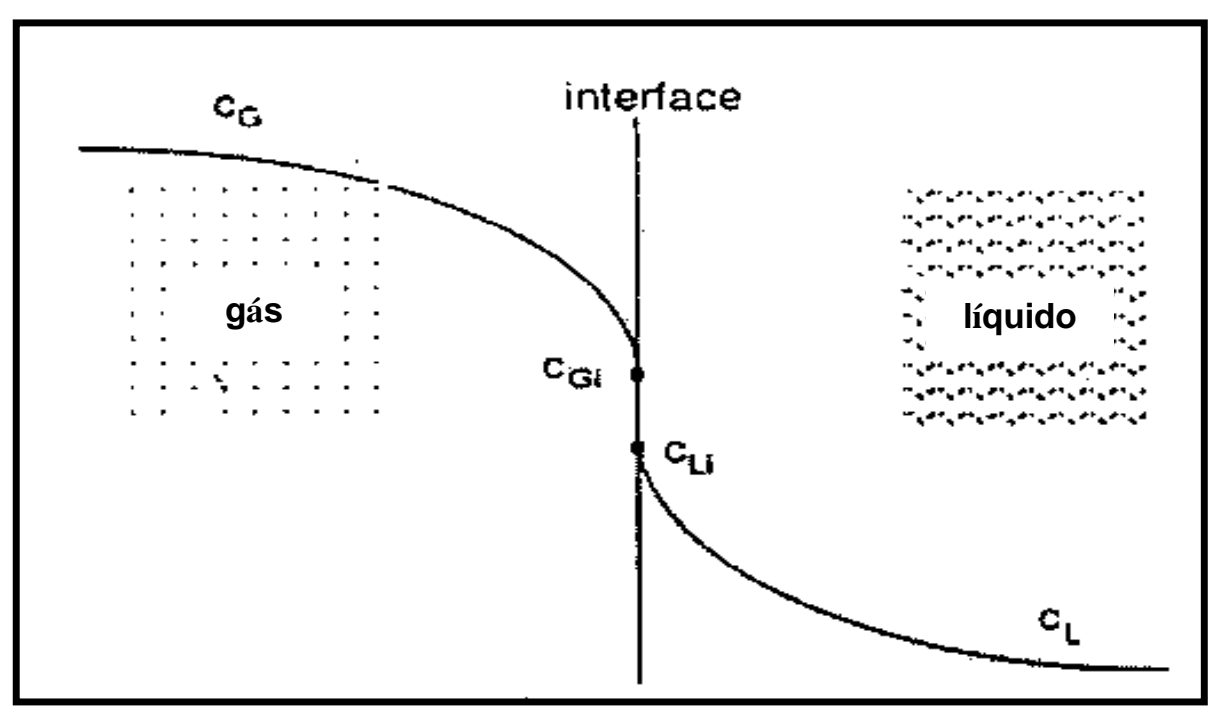

Figura 11. Esquema da interface gás-líquido ${ }^{14}$.

Para determinar-se o coeficiente de transferência de massa $\left(K_{\mathrm{L}} \mathrm{a}\right)$ é necessário calcular-se o balanço de massa na fase limitante (líquida). Este balanço é descrito pela equação 39, que estabelece relações entre as concentrações de ozônio em solução em função do tempo.

$$
\mathrm{dC}_{\mathrm{L}} / \mathrm{dt}=\mathrm{K}_{\mathrm{L}} \mathrm{a}\left(\mathrm{C}_{\mathrm{L}}^{\text {sat }}-\mathrm{C}_{\mathrm{L}}\right)-\mathrm{K}_{\mathrm{d}} \mathrm{C}_{\mathrm{L}}
$$

Onde:

$\mathrm{K}_{\mathrm{L}} \mathrm{a}=$ coeficiente de transferência de massa para a fase líquida em $\min ^{-1}$.

$\mathrm{C}_{\mathrm{L}}{ }^{\text {sat }}=$ concentração de saturação de ozônio no líquido em $\mathrm{mg} \mathrm{L}^{-1}$, nas condições de operação (temperatura $(\mathrm{T})$, pressão parcial de ozônio $\left(\mathrm{p}_{\mathrm{O}}\right)$ )).

$C_{L}=$ concentração de ozônio na solução em $\mathrm{mg} \mathrm{L}^{-1}$.

$\mathrm{K}_{\mathrm{d}}=$ constante de decomposição de ozônio $\left(\mathrm{min}^{-1}\right)$.

$\mathrm{t}=$ tempo de ozonização $(\min )$. 
Sob condições hidrodinâmicas, a pH e temperatura constantes, o coeficiente $\mathrm{K}_{\mathrm{L}}$ a pode ser determinado pela equação 40 :

$$
\begin{gathered}
\frac{C_{L}^{*}-C_{L}}{C_{L}}=e^{K_{L a} \cdot t} \\
C_{\mathrm{C}=\text { concentração no instante } \mathrm{t}} \\
\mathrm{C}_{\mathrm{L}=\text { concentração de equilíbrio }} \\
\mathrm{C}=\text { tempo }
\end{gathered}
$$

Os valores de $\mathrm{K}_{\mathrm{L}}$ a são de grande interesse para a caracterização dos sistemas de ozonização. A partir de tais valores podem-se estabelecer comparações de processos realizados em diferentes condições reacionais.

Nos experimentos de determinação de $\mathrm{K}_{\mathrm{L}} \mathrm{a}$, utilizou-se água deionizada com o pH ajustado para um valor igual a 3, sendo que o reator foi mantido a uma temperatura de $25{ }^{\circ} \mathrm{C}$. Nestas condições, o ozônio apresenta uma menor velocidade de autodecomposição, permitindo que a concentração de ozônio dissolvido no líquido possa ser determinada pelo método iodométrico ${ }^{78}$. A Figura 12 mostra os valores de concentração de ozônio dissolvido em função do tempo de exposição do meio aquoso a este gás, em duas diferentes vazões de entrada. 


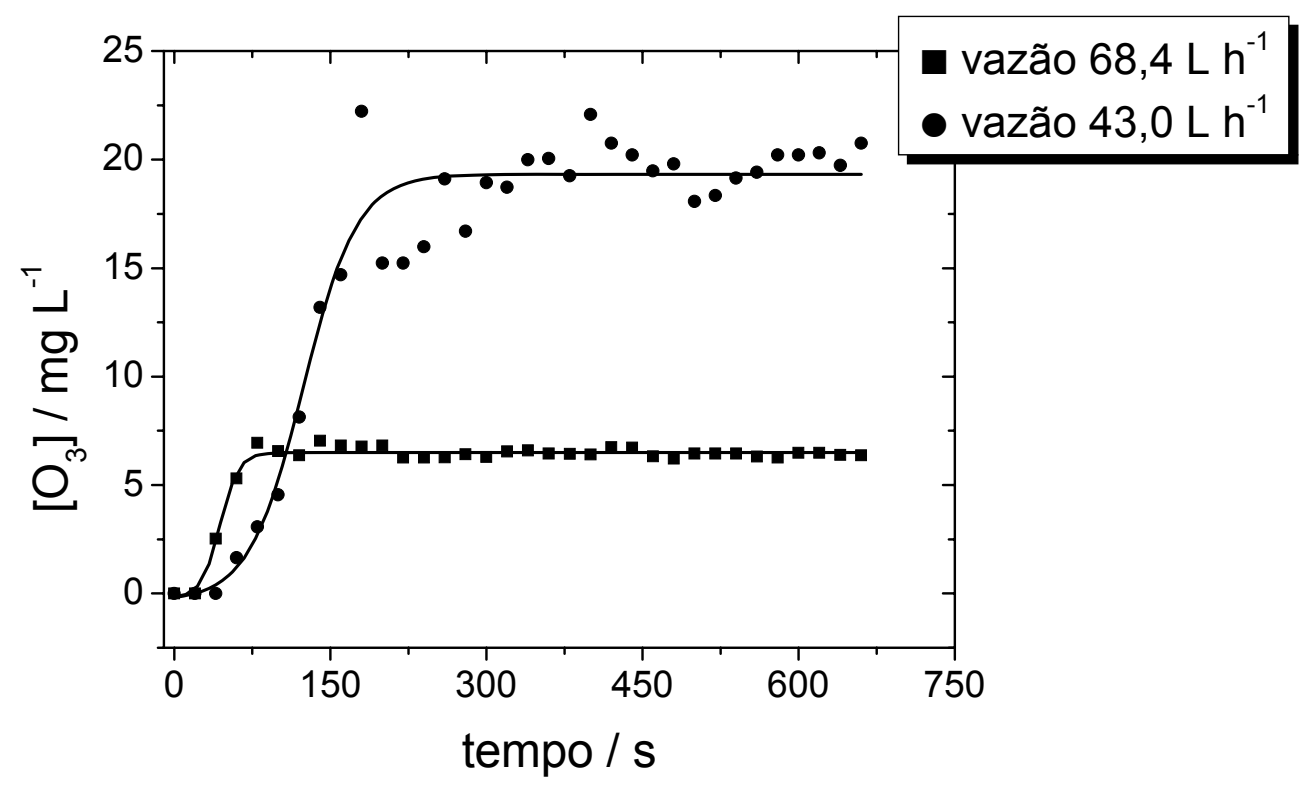

Figura 12. Variação da concentração de ozônio no meio aquoso em função do tempo. Potencial aplicado para a geração de ozônio: 5 kV.

Este comportamento exponencial pode ser ajustado pela função sigmoidal de Swibull (descrita pela equação: $\left.y=A-(A-B) e^{-k x}\right)$. Aplicando-se este ajuste para os dados experimentais e considerando-se que a concentração de saturação seja equivalente a concentração de equilíbrio, obtém-se um valor de $\mathrm{K}_{\mathrm{L} a}=2,20 \mathrm{e}$ 0,39 min $^{-1}$ para as vazões de 68,4 e 43,0 L h $\mathrm{h}^{-1}$, respectivamente. O KLa é um dos principais parâmetros utilizados na caracterização e estabelecimento da capacidade do sistema em transferir ozônio à solução, sendo dependente também da geometria e configuração do reator ${ }^{76}$.

\subsubsection{Monitoramento da produção de ozônio}

A quantidade de ozônio que interage com os compostos a serem degradados pode ser estimada por uma série de métodos ${ }^{14}$. Usualmente, ela é 
reportada como dose aplicada ou como dose consumida (também chamada de transferida). Devido aos problemas de transferência de massa e cinética de reação, a utilização somente dos valores de dose aplicada, pode conduzir a conclusões errôneas, pois boa parte do ozônio pode passar pelo reator sem ser transferido para o meio líquido (e/ou reagir com os compostos de interesse). Desta forma, o valor de ozônio transferido costuma ser mais informativo, uma vez que o mesmo pode indicar a quantidade de ozônio dissolvido disponível para a oxidação.

Convencionalmente, o valor da dose de ozônio consumido é obtido subtraindo-se a concentração de ozônio na saída do reator por aquela presente inicialmente em sua entrada ${ }^{26,79}$. Tal abordagem no cálculo da dose consumida, não discrimina o ozônio requerido para a saturação da amostra líquida ou qualquer outra perda devido à decomposição do ozônio na fase líquida ou no volume livre do reator (“headspace”). Entretanto, esta possível superestimativa pode ser desprezível quando comparada com a quantidade de ozônio usada para promover as reações de oxidação e, por isso, costuma ser negligenciada.

Tal como descrito no item 3.1, a concentração de ozônio produzida foi monitorada verificando-se a variação da absorção de radiação eletromagnética pelo ozônio gasoso na região do ultravioleta $\left(\lambda_{\max }=258 \mathrm{~nm}\right)$. Através do uso de válvulas, foi possível monitorar, continuamente e em tempo real, a quantidade de ozônio presente no sistema, passando ou não pela amostra acondicionada no reator. A Figura 13 mostra um comportamento característico da variação da absorbância (correlacionada, pela lei de Lambert-Beer, com a concentração de ozônio) durante um processo de ozonização. 


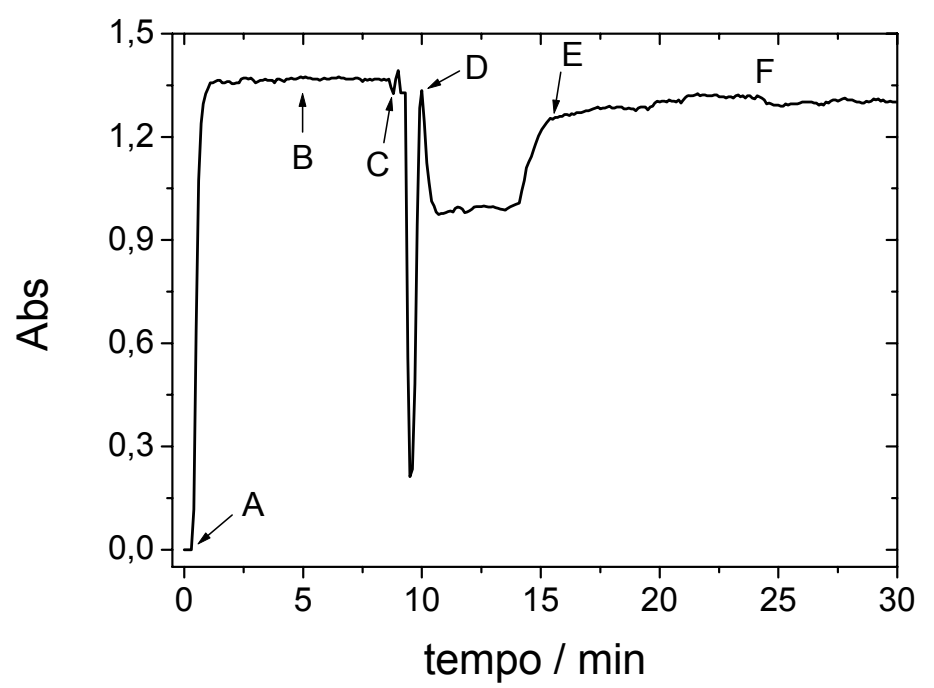

Figura 13. Variação da absorção de radiação UV $(\lambda=258 \mathrm{~nm})$ pelo ozônio gasoso durante um processo de ozonização. Vazão de $\mathrm{O}_{2}=54 \mathrm{~L} \mathrm{~h}^{-1}$.

Na figura acima, pode-se observar que, imediatamente após o início da aplicação de potencial entre os eletrodos do ozonizador (ponto $A$ ), há um incremento na absorbância devido ao aumento na concentração de ozônio na fase gasosa. Após poucos minutos, a produção de ozônio atinge um patamar (ponto $\mathrm{B}$, que conforme discutido previamente, é dependente da diferença de potencial aplicado e da vazão do gás de entrada), que se mantêm estável até que o fluxo de gás seja desviado para adentrar no reator (ponto C). Nesta situação, observa-se uma queda brusca da absorbância, até haver o preenchimento do reator/sistema, então ela sobe novamente (região entre os pontos C e D). Após esta situação, a concentração de ozônio na fase gasosa passa a ser limitada pela saturação do líquido (transferência de fase do ozônio) e pela reação do $\mathrm{O}_{3}$ com os compostos-alvo (região entre os pontos D e E). À medida que a velocidade de reação entre o ozônio e os substratos diminui (com a concomitante formação de 
produtos finais recalcitrantes a oxidação), a concentração de ozônio aquoso aumenta tendendo para o limite de solubilidade. Qualquer quantidade de ozônio aplicada adicionalmente não irá ser utilizada e o ponto no qual isto ocorre pode ser usado para otimizar o processo e evitar a aplicação de excesso de ozônio (ponto F). Para a maioria dos experimentos realizados neste estudo esta região foi atingida após cerca de 15 minutos de ozonização, sendo que de um modo geral, os processos foram interrompidos após 30 minutos de tratamento.

Apesar de bastante simples e eficiente, este método de monitoramento apresenta algumas limitações quanto à quantidade de ozônio a ser analisada, a qual deve estar dentro de uma faixa de valores que obedeçam à lei de LambertBeer (ou seja, correlação linear entre a absorbância e a concentração do analito, idealmente com absorbâncias inferiores a 1). Tal limitação foi considerada no estabelecimento das condições de ozonização descritas no item 4.1.1 e não impôs nenhum prejuízo significativo aos demais estudos desenvolvidos neste trabalho.

Após o desenvolvimento, avaliação e caracterização dos principais parâmetros operacionais do sistema de ozonização implementado, procedeu-se o estudo da degradação de corantes, tema que será abordado nos próximos itens.

\subsection{Estudo da degradação e mineralizaçao de corantes por diferentes processos de ozonização}

A eficiência do processo de ozonização na degradação de corantes foi avaliada empregando-se três corantes representativos das principais classes de grupos cromóforos constituintes dos corantes reativos: Preto Remazol B 
(azocorante), Azul Remazol Brilhante RN (antraquinona) e Turquesa Remazol G 133 (ftalocianina). Dentre estes diferentes tipos de corantes, o azocorante Preto Remazol B foi escolhido como composto modelo para avaliação dos processos de ozonização estudados, pois a classe a que pertence corresponde a cerca de $60 \%$ dos corantes atualmente utilizados no mundo ${ }^{5}$.

A ozonização deste corante foi realizada sob diferentes condições experimentais as quais visavam aumentar a eficiência deste processo, principalmente com relação à mineralização deste composto. Nos próximos itens serão apresentados os principais resultados observados, empregando-se ozônio em diferentes pHs, na presença de peróxido de hidrogênio e de íons de metais de transição (ferro e manganês). A influência destes íons metálicos também foi avaliada em sistemas heterogêneos, principalmente empregando-se sílica mesoestruturada como suporte para os mesmos.

\subsubsection{Ozonização do corante modelo Preto Remazol B}

\subsubsection{Degradação do corante}

A degradação dos grupos cromóforos, e conseqüente, eliminação da coloração, é um dos principais objetivos que normalmente se busca quando se realiza o tratamento de efluentes têxteis que são altamente coloridos. Os grupos cromóforos das moléculas dos corantes orgânicos são geralmente constituídos por anéis aromáticos conjugados com ligações duplas do tipo carbono-carbono, carbono-oxigênio, carbono nitrogênio e nitrogênio-nitrogênio ${ }^{6}$. Estas ligações podem ser clivadas via interação com ozônio, dando origem a outras moléculas 
de menor complexidade, as quais geralmente não possuem a propriedade de absorver radiação na região visível do espectroeletromagnético ${ }^{9}$.

A Figura 14 mostra a variação observada na absorção da radiação eletromagnética, na região do UV/Vis, pelo corante Preto Remazol B após diferentes tempos de ozonização em meio ácido $(\mathrm{pH}=3)$.

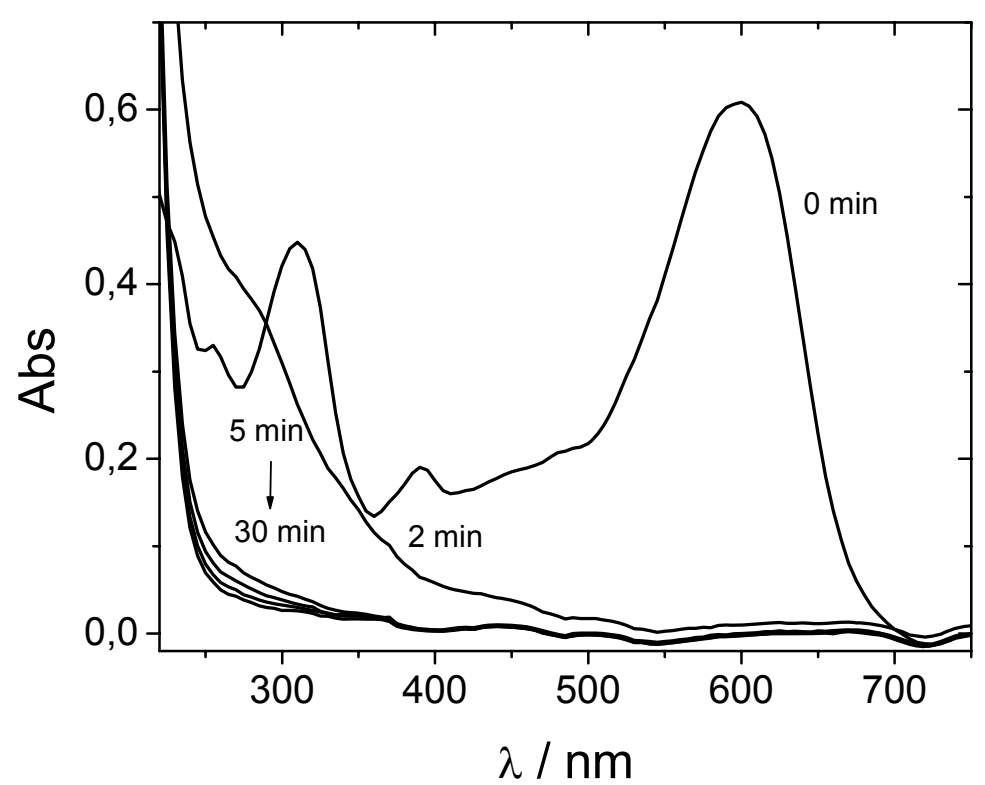

Figura 14. Espectro UV/Vis de uma solução do corante Preto Remazol B após diferentes tempos de tratamento por ozonização. Condições experimentais: $\mathrm{pH}=3$; $[\text { corante }]_{0}=100 \mathrm{mg} \mathrm{L}^{-1}$; vazão de $\mathrm{O}_{2}=54 \mathrm{~L} \mathrm{~h}^{-1}$.

De um modo geral, em tempos inferiores a 2 minutos de tratamento, observou-se uma redução na absorção na região do visível superior a 99,9\% (cálculo realizado considerando-se a absorção em $\lambda_{\max }=600 \mathrm{~nm}$ ). A eficiência do ozônio na redução da coloração tem sido comprovada em uma série de trabalhos ${ }^{80-82}$, mesmo quando os corantes estão presentes em matrizes 
complexas como, por exemplo, efluentes industriais têxteis ${ }^{83}$. Shu e Huang ${ }^{81}$ observaram uma excelente cinética de degradação dos grupos cromóforos de oito azocorantes, com eliminação completa da coloração em menos de 5 minutos de tratamento com ozônio. Resultados similares foram observados quando os autores empregaram uma mistura contendo todos os corantes estudados. Lin e Liu $^{82}$ também observaram uma completa descoloração de efluentes têxteis em tempos reduzidos de ozonização.

A eficiência do ozônio na degradação dos grupos cromóforos não foi tão elevada com relação à diminuição da concentração de carbono orgânico total do corante Preto Remazol B, conforme apresentado na Figura 15. Nesta figura podese observar que cerca de $30 \%$ do teor de matéria orgânica inicial foi mineralizada nos primeiros 15 minutos de ozonização. Após o dobro deste tempo, praticamente não se verificou uma alteração significativa na concentração de carbono orgânico total. Conforme previamente mencionado, o processo de ozonização costuma ser mais eficiente na oxidação de compostos nucleofílicos insaturados com alta densidade eletrônica ${ }^{14,18}$ (por exemplo: alquenos, alquinos, anéis aromáticos, etc). No decorrer da interação destes compostos com o ozônio ocorre transferência eletrônica e a formação de sub-produtos da oxidação incompleta, os quais geralmente possuem uma disponibilidade de elétrons menor e são mais recalcitrantes ao ataque do ozônio ${ }^{14}$. 


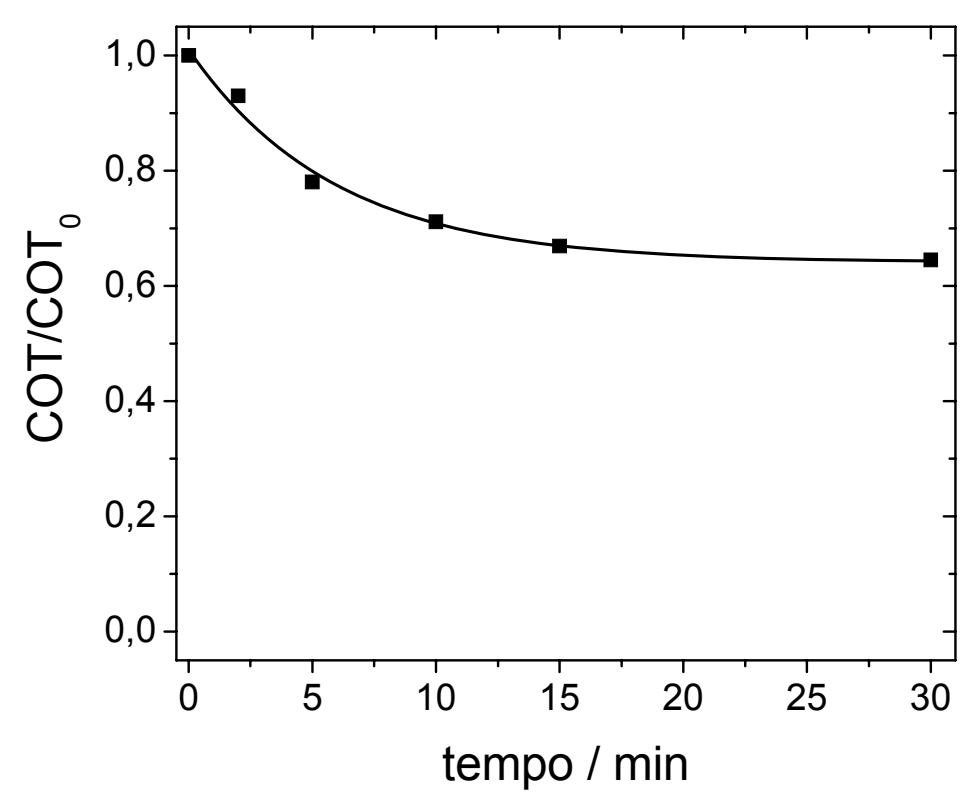

Figura 15. Variação da concentração de carbono orgânico total em função do tempo de ozonização de uma solução do corante Preto Remazol B. Condições experimentais: $\mathrm{pH}=3$; [corante] $]_{0}=100 \mathrm{mg} \mathrm{L}^{-1}$; vazão de $\mathrm{O}_{2}=54 \mathrm{~L} \mathrm{~h}^{-1}$.

Devido a esta característica, adotou-se a porcentagem e a cinética de mineralização dos corantes estudados como os parâmetros primordiais de avaliação da eficiência dos diferentes processos de ozonização empregados. Além disso, de um modo geral, a descoloração dos corantes apresentou uma elevada eficiência (> 99\% de remoção da cor) e rápida cinética (estes percentuais de redução de cor foram obtidos empregando-se os processos de ozonização entre 0,5 e 2 minutos). Nas condições experimentais adotadas para monitorar a descoloração, não se obteve uma distinção nítida entre os resultados dos diferentes tratamentos, limitando a utilização deste parâmetro para a avaliação dos processos empregados.

Diante disso uma maior ênfase será direcionada à mineralização obtida 
com os diferentes processos de ozonização estudados, sendo a discussão a respeito do ganho de eficiência por estes processos limitada a avaliação de características correlacionadas a este parâmetro.

\subsubsection{Influência do pH no processo de ozonização}

Como já mencionado anteriormente, o ozônio em meio ácido tende a reagir via o mecanismo direto (ataque do ozônio molecular aos compostos-alvo). Nestas condições, a redução no teor de carbono orgânico costuma ser menos eficiente ${ }^{19-}$

21. Por outro lado, em meio básico, o ozônio pode interagir com ânions hidroxila, levando a formação de espécies radicalares, principalmente o radical hidroxila (HO). Devido ao caráter não seletivo dos radicais hidroxila, o mecanismo de ozonização indireto é em geral mais eficiente na oxidação de compostos $\operatorname{orgânicos}^{14,26,27}$. O efeito do $\mathrm{pH}$, no meio reacional, sobre a eficiência da ozonização na mineralização do corante Preto Remazol B é apresentado na Figura 16.

Através da análise dos resultados obtidos, pode-se observar que o teor de mineralização do corante aumenta à medida em que se elevou o pH do meio. Quando o pH inicial da solução de corante foi alterado de 3 para 8, observou-se um aumento de $25 \%$ na remoção de COT (redução na concentração de COT de $33 \%$ e $41 \%$ em pH 3 e 8 , respectivamente) após 30 minutos de ozonização. Neste mesmo tempo de tratamento, obteve-se uma mineralização de $56 \%$ quando eleva-se o pH da solução para 11 (melhora de aproximadamente $70 \%$, quando comparado com os resultados obtidos em meio ácido). 


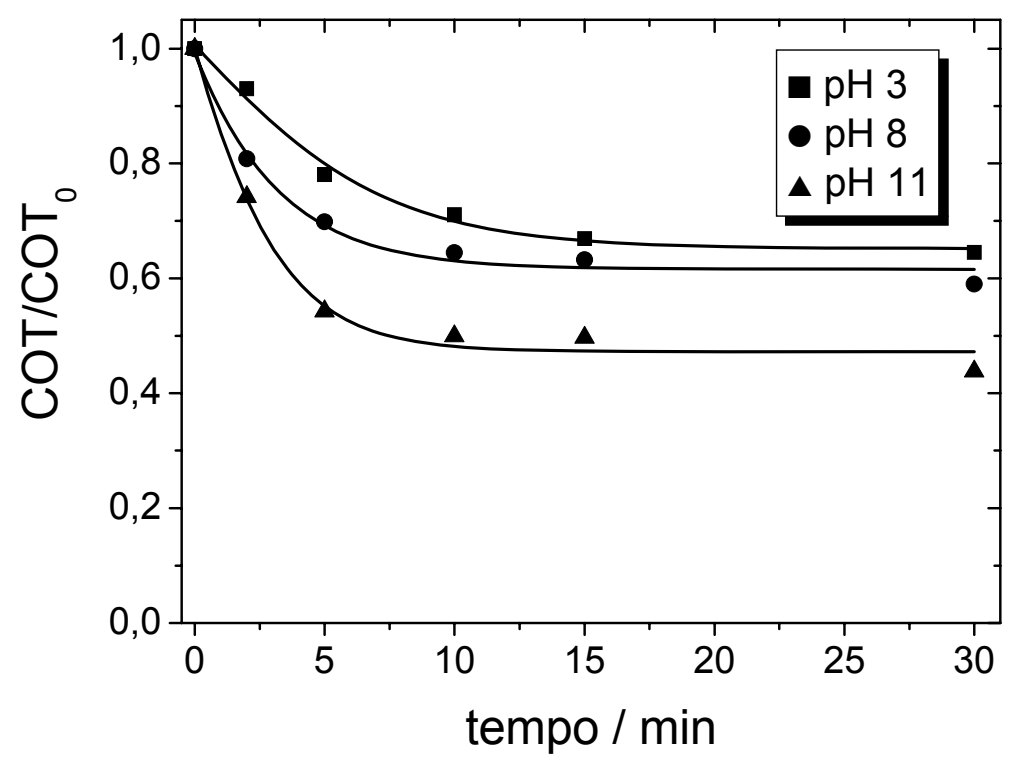

Figura 16. Variação da concentração de carbono orgânico total em função do tempo de ozonização de uma solução do corante Preto Remazol B com diferentes pHs iniciais. Condições experimentais: [corante $]_{0}=100 \mathrm{mg} \mathrm{L}^{-1}$; vazão de $\mathrm{O}_{2}=54 \mathrm{~L} \mathrm{~h}^{-1}$.

Tanto a reação do ozônio com os ânions hidroxila, quanto os produtos de degradação formados pela oxidação via radical hidroxila (geralmente ácidos carboxílicos) tendem a diminuir o pH da solução durante o tratamento. A Figura 17 mostra que esta variação é bastante pronunciada nos instantes iniciais do processo (principalmente para soluções com o meio mais próximo da neutralidade) em que há um maior consumo de ozônio e transformação (degradação/mineralização) do composto alvo. Aparentemente, o processo de ozonização poderia ter um desempenho superior se $\mathrm{o} \mathrm{pH}$ fosse ajustado continuamente durante o tratamento ou se o meio fosse tamponado. Por motivos operacionais e priorização de metas, estas duas situações não foram avaliadas no presente trabalho. 


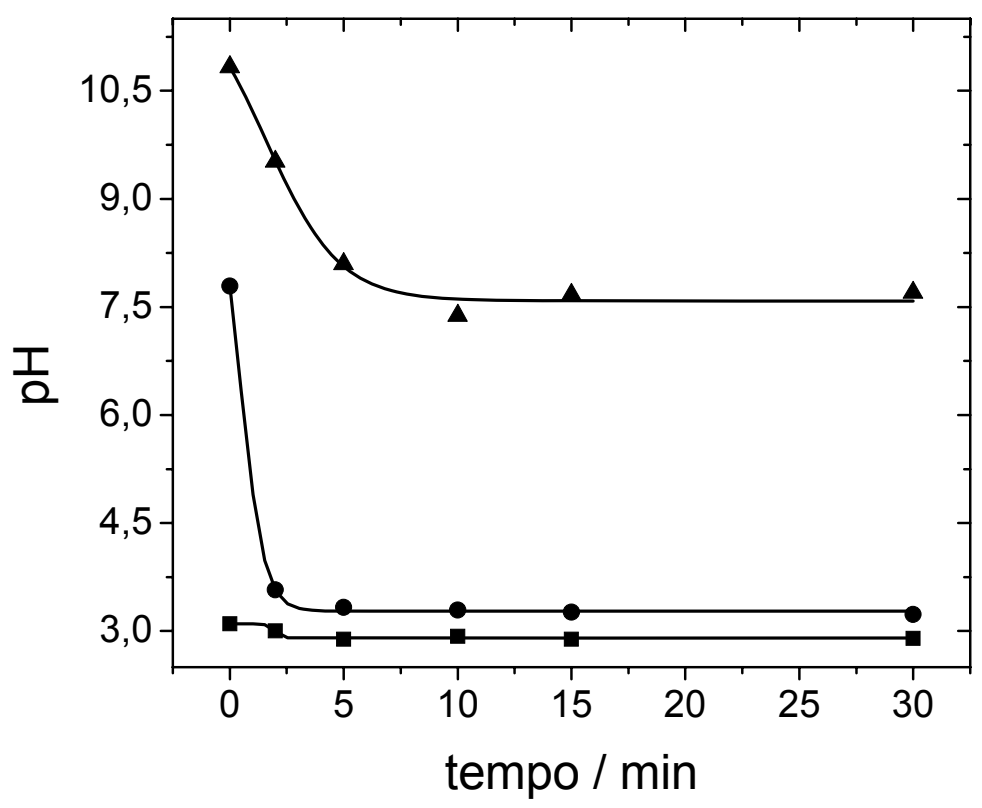

Figura 17. Variação do pH em função do tempo de ozonização de uma solução do corante Preto Remazol B com diferentes pHs iniciais. Condições experimentais: [corante] $]_{0}=100 \mathrm{mg} \mathrm{L}^{-1}$; vazão de $\mathrm{O}_{2}=54 \mathrm{~L} \mathrm{~h}^{-1}$.

A Figura 16 mostra que os processos de ozonização apresentaram uma taxa de remoção de COT com perfil similar ao observado por sistemas que seguem o modelo cinético de pseudo-primeira ordem. Tal modelo cinético é baseado na proporcionalidade entre a concentração de uma espécie $A$ e a sua velocidade de degradação, quando a concentração de eventuais outras espécies se mantém constante e em excesso ${ }^{15}$. Rigorosamente, tal abordagem não pode ser aplicada diretamente à modelagem da cinética da mineralização, pois a concentração de carbono orgânico total não corresponde a uma única espécie, mas sim ao composto alvo remanescente e a todos os eventuais sub-produtos gerados devido a sua oxidação incompleta, que podem possuir reatividades extremamente distintas frente às espécies oxidantes empregadas. Feita esta consideração, neste trabalho adotou-se que o teor de COT correspondia a um 
parâmetro global, para o qual foi verificada a taxa de redução em função do tempo de tratamento. Neste caso, tal qual nos sistemas ordinários de pseudoprimeira ordem, buscou-se avaliar a cinética de remoção de COT determinandose uma constante aparente de remoção $\left(k_{\text {obs }}\right)$ entre a taxa de mineralização e o tempo de tratamento. Esta constante foi determinada graficamente através da linearização da equação:

$$
\mathrm{dC} / \mathrm{dt}=\mathrm{k}_{\mathrm{obs}} \mathrm{C}
$$

Da qual obteve-se a expressão:

$$
-\ln \left(C / C_{0}\right)=k_{\exp } \mathrm{t}
$$

onde $\mathrm{C}_{0}$ e $\mathrm{C}$ são as concentrações de carbono orgânico total do corante no tempo 0 e $t$, respectivamente.

A Tabela 4 mostra a constante aparente de remoção de COT para os processos de ozonização realizados em diferentes pHs iniciais do meio reacional.

Tabela 4. Variação da constante aparente de remoção de COT do processo de ozonização do corante Preto Remazol B em diferentes pHs iniciais. Condições experimentais: [corante $]_{0}=100 \mathrm{mg} \mathrm{L}^{-1}$; vazão de $\mathrm{O}_{2}=$ $54 \mathrm{~L} \mathrm{~h}^{-1}$.

\begin{tabular}{|c|c|}
\hline $\mathbf{p H}$ & $\mathbf{k}_{\text {obs }}\left(\mathbf{m i n}^{-1}\right)$ \\
\hline $\mathbf{3}$ & $0,035 \pm 0,007$ \\
$\mathbf{8}$ & $0,041 \pm 0,013$ \\
$\mathbf{1 1}$ & $0,067 \pm 0,021$ \\
\hline
\end{tabular}

Confirmando o que foi constatado previamente, há um aumento na taxa de remoção de COT em função do aumento do pH do meio reacional $\left(\mathrm{k}_{\mathrm{obs}} \mathrm{em} \mathrm{pH} 11\right.$ 
é cerca de $92 \%$ superior a obtida em $\mathrm{pH} 3$ ). Ou seja, o processo de ozonização, na qual há formação de espécies radicalares, não só apresenta uma magnitude maior na remoção de COT, como esta também se procede de forma mais rápida.

Além da taxa de mineralização, o consumo do ozônio em função do tempo de tratamento também pode ser utilizado como parâmetro para se caracterizar os processos de ozonização estudados. A Figura 18 mostra a variação no consumo de ozônio durante o tratamento de uma solução $100 \mathrm{mg} \mathrm{L}^{-1}$ do azocorante Preto Remazol B, com pH inicial igual a 3. Nesta figura, pode-se notar que há um grande consumo de ozônio nos primeiros 10 minutos de tratamento, sendo que, após este tempo, a variação na concentração de ozônio consumido diminui, tendendo para uma situação onde não há mais consumo deste gás.

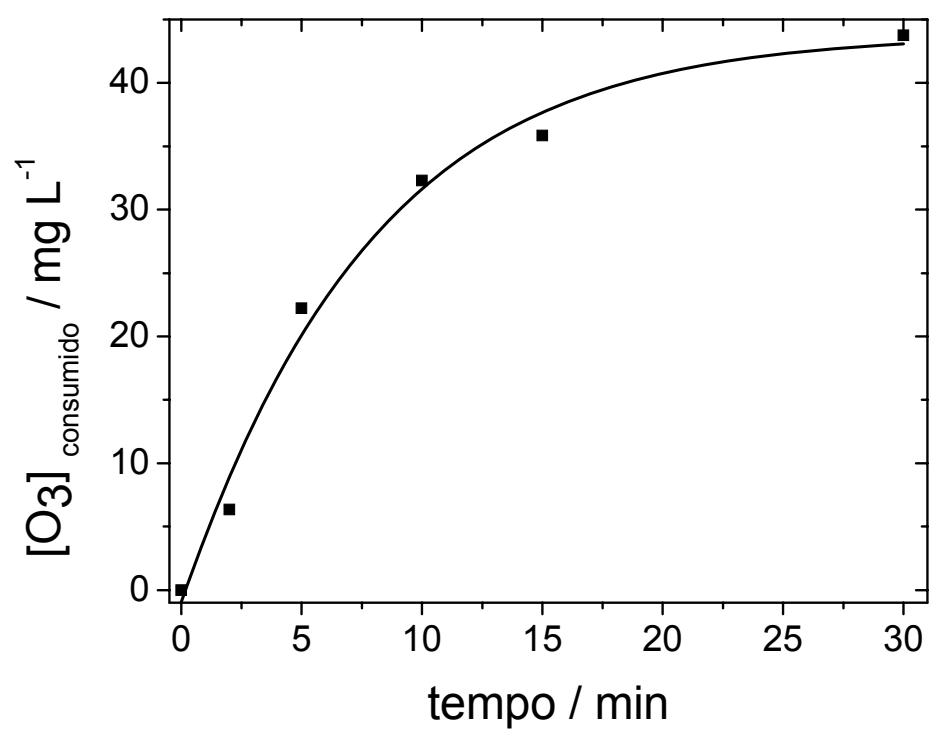

Figura 18. Variação do ozônio consumido em função do tempo de ozonização de uma solução do corante Preto Remazol B. Condições experimentais: $\mathrm{pH}=3$; [corante $]_{0}=100 \mathrm{mg} \mathrm{L}^{-1}$; vazão de $\mathrm{O}_{2}=54 \mathrm{~L} \mathrm{~h}^{-1}$. 
Tal comportamento é similar à redução observada na concentração de COT em função do tempo de tratamento, sugerindo uma correlação direta entre a quantidade de ozônio consumido e a mineralização do composto modelo. A Figura 19 mostra que esta correlação é linear, sendo que o coeficiente angular desta reta foi adotado para estimar a quantidade de ozônio necessária para mineralizar o azocorante estudado. Este parâmetro foi denominado razão de consumo $\left(Q_{\text {cons }}\right)$ e quanto menor seu valor nominal, mais eficiente seria $o$ processo de ozonização. Idealmente, a partir deste parâmetro e conhecendo-se a concentração de COT inicial, pode-se estimar a quantidade de ozônio necessária para a completa mineralização do composto alvo ou a razão entre a quantidade de ozônio consumido e a quantidade de matéria orgânica mineralizada ( $\mathrm{mgoz}_{\mathrm{mg}} / \mathrm{mgT}_{\text {с }}$.

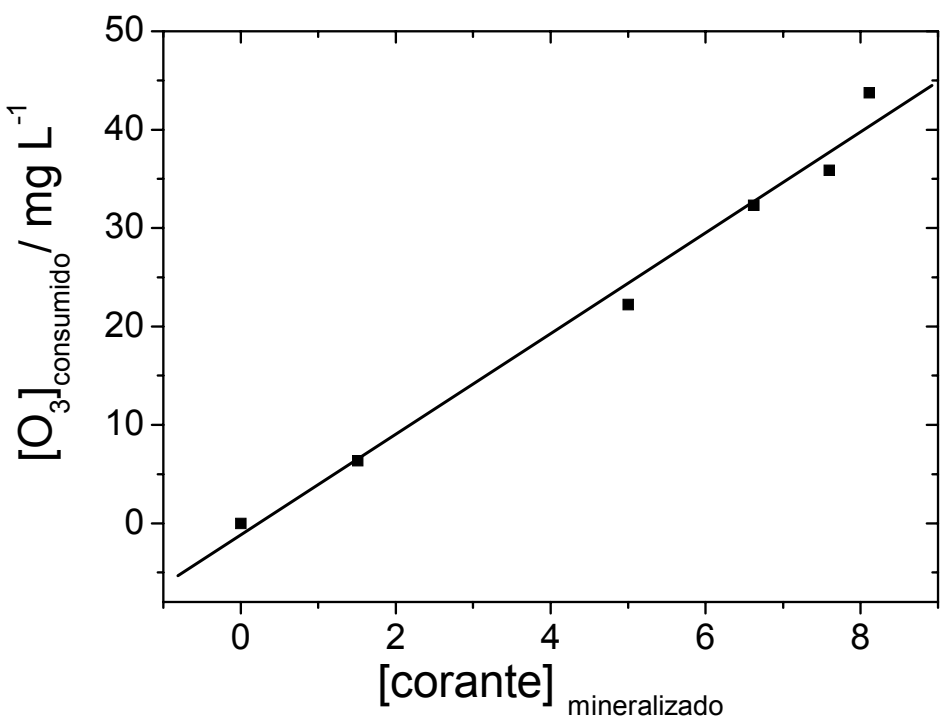

Figura 19. Variação da quantidade de ozônio consumido em função da concentração mineralizada de uma solução do corante Preto Remazol B. Condições experimentais: $\mathrm{pH}=3$; [corante $]_{0}=100 \mathrm{mg} \mathrm{L}^{-1}$; vazão de $\mathrm{O}_{2}=$ $54 \mathrm{~L} \mathrm{~h}^{-1}$. 
A Tabela 5 mostra a razão de consumo de ozônio, em função do pH inicial da solução empregada, no processo de ozonização do azocorante.

Tabela 5. Variação da razão de consumo de ozônio em função do pH inicial da solução de Preto Remazol B.

\begin{tabular}{|c|ccc|}
\hline $\mathbf{p H}$ & $\mathbf{3}$ & $\mathbf{8}$ & $\mathbf{1 1}$ \\
\hline $\mathbf{Q}_{\text {cons }}$ & 4,7 & 3,2 & 3,0 \\
\hline
\end{tabular}

Pode-se inferir que, com o aumento do pH, tem-se uma diminuição na razão de consumo, mostrando que, mesmo apresentando um aumento na mineralização, há um menor consumo de ozônio. Tal comportamento pode ser atribuído à formação de radicais hidroxila que são mais efetivos na mineralização de matéria orgânica. Além disso, devido a sua natureza radicalar o mecanismo de oxidação indireta envolve uma série de reações em cadeia que possui rotas de regeneração das espécies radicalares, promovendo um ganho estequiométrico na degradação do poluente alvo.

Os resultados apresentados acima mostram que a geração de espécies radicalares, a partir do ozônio, tem um efeito intensificador da mineralização de compostos orgânicos. Obter este efeito foi um dos principais objetivos deste trabalho. Entretanto, a utilização de meio básico para este fim é um procedimento bastante conhecido ${ }^{84}$, sendo assim neste trabalho buscou-se implementar/estudar outras formas de aumentar a eficiência dos processos de ozonização. Desta forma, optou-se por ajustar o valor de pH das soluções a serem ozonizadas, nas diferentes abordagens experimentais, para 3. Nestas condições, um eventual 
ganho na eficiência de mineralização poderia ser atribuída às modificações dos processos de ozonização e não apenas a uma alteração no pH reacional.

\subsubsection{Influência da adição de peróxido de hidrogênio}

Uma das estratégias para promover uma melhora na mineralização do azocorante Preto Remazol B, pelo processo de ozonização em meio ácido, foi a adição de peróxido de hidrogênio ao meio reacional. Tal como mencionado anteriormente, $\mathrm{o} \mathrm{H}_{2} \mathrm{O}_{2}$ na presença de ozônio pode promover a formação de radicais hidroxila ${ }^{49,85}$. O processo $\mathrm{O}_{3} / \mathrm{H}_{2} \mathrm{O}_{2}$ também é conhecido como peroxone, sendo que seu mecanismo de ação é baseado no fato de que a base conjugada do $\mathrm{H}_{2} \mathrm{O}_{2}$ poder iniciar as reações de decomposição do ozônio, as quais levam à formação de $\cdot \mathrm{OH}^{14}$.

Na Figura 20 pode-se observar que a adição de $\mathrm{H}_{2} \mathrm{O}_{2}$ não aumentou a velocidade de mineralização do corante comparando-se com o processo realizado na ausência deste reagente $\left(k_{\text {obs }}\right.$ igual a 0,038 $\pm 0,005 \mathrm{~min}^{-1}$ e 0,035 $\pm 0,007 \mathrm{~min}^{-1}$ para $\mathrm{O}_{3} / \mathrm{pH}_{3} / \mathrm{H}_{2} \mathrm{O}_{2}$ e $\mathrm{O}_{3} / \mathrm{pH} 3$, respectivamente). Por outro lado, após 30 minutos de tratamento, o processo conduzido com $\mathrm{H}_{2} \mathrm{O}_{2}$ permitiu uma mineralização superior (aproximadamente 40\%) à obtida sem a presença de peróxido. Tal comportamento pode ser interpretado considerando-se que compostos que possuem uma alta reatividade com ozônio praticamente não apresentam sua cinética e taxa de mineralização alterados pela adição de peróxido de hidrogênio. Este comportamento foi relatado por Brunet e colaboradores ${ }^{86}$ para os casos dos ácidos benzaldeído e ftálico, os quais possuem no anel aromático substituintes com grupos funcionais reativos frente ao ozônio molecular. A principal vantagem 
do processo com peróxido de hidrogênio reside na remoção de compostos não reativos (ou com baixa reatividade) com ozônio. No trabalho acima relatado, foi demonstrado, por exemplo, que o ácido oxálico (subproduto bastante comum nas reações com ozônio) teve sua cinética de degradação significativamente acelerada com a adição de peróxido de hidrogênio.

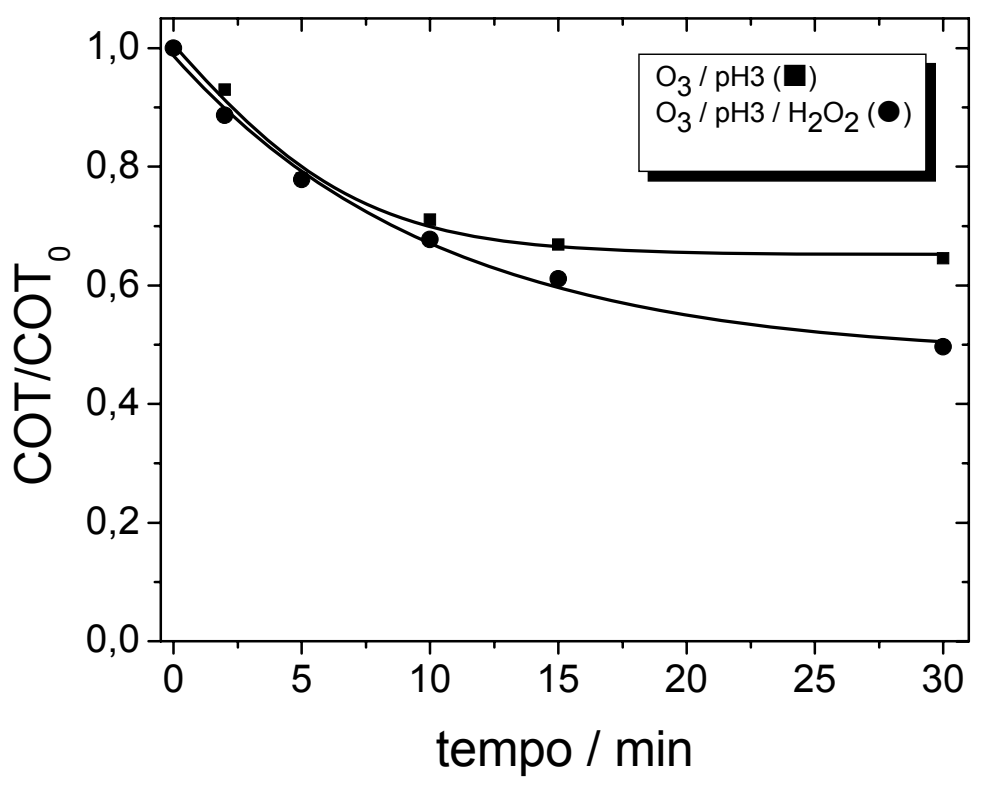

Figura 20. Variação da concentração de carbono orgânico total em função do tempo de ozonização de uma solução do corante Preto Remazol B usando uma concentração de $10,0 \times 10^{-3} \mathrm{~mol} \mathrm{~L}^{-1}$ de peróxido de hidrogênio. Condições experimentais: $\mathrm{pH}=3$; [corante] $]_{0}=100 \mathrm{mg} \mathrm{L}^{-1}$; vazão de $\mathrm{O}_{2}=54 \mathrm{~L} \mathrm{~h}^{-1}$.

A razão de consumo apresentada pelo processo $\mathrm{O}_{3} / \mathrm{pH} 3 / \mathrm{H}_{2} \mathrm{O}_{2}$ foi de 4,0 . Este valor é menor do que o valor apresentado pela a solução na ausência de $\mathrm{H}_{2} \mathrm{O}_{2}$ mostrando que há a necessidade de uma quantidade menor de ozônio para alcançar o mesmo grau de mineralização. 
$\mathrm{O} \mathrm{H}_{2} \mathrm{O}_{2}$ atua como um iniciador/ativador da decomposição do ozônio, porém pode funcionar como uma espécie seqüestradora (consumidora) de radicais hidroxila (equações 17 e 18). Desta forma, deve-se avaliar o efeito da concentração de peróxido sobre a eficiência do processo, uma vez que doses de peróxido de hidrogênio que excedem a concentração ótima devem inibir as reações de oxidação ${ }^{30,87}$.

A Figura 21 mostra que o aumento na mineralização do corante ocorre até uma concentração de $\mathrm{H}_{2} \mathrm{O}_{2}$ igual a $10,0 \times 10^{-3} \mathrm{~mol} \mathrm{~L}^{-1}$. Entretanto, elevando-se a concentração inicial de $\mathrm{H}_{2} \mathrm{O}_{2}$ de $10,0 \times 10^{-3}$ para $30,0 \times 10^{-3} \mathrm{~mol} \mathrm{~L}^{-1}$ pode-se observar uma redução no desempenho do processo $\mathrm{O}_{3} / \mathrm{pH} 3 / \mathrm{H}_{2} \mathrm{O}_{2}$.

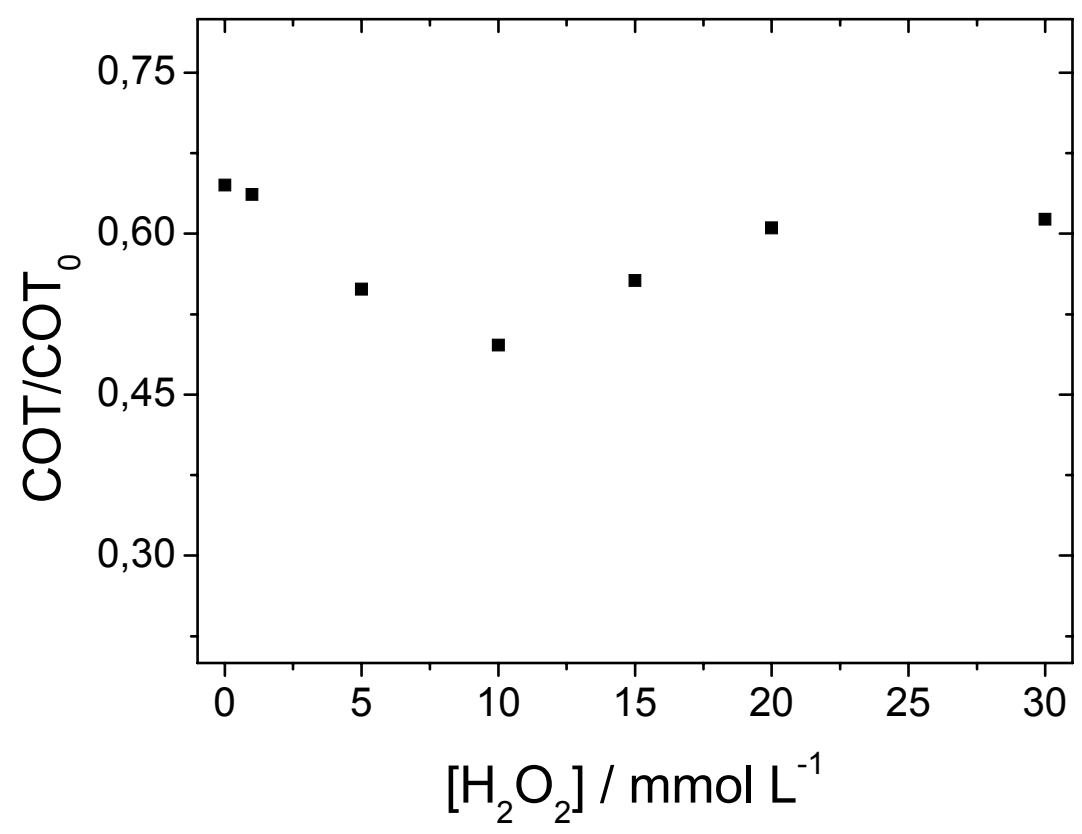

Figura 21. Variação da concentração do carbono orgânico total em função da concentração de peróxido de hidrogênio de uma solução do corante Preto Remazol B após 30 minutos de ozonização. Condições experimentais: $\mathrm{pH}=3$; [corante $]_{0}=100 \mathrm{mg} \mathrm{L}^{-1}$; vazão de $\mathrm{O}_{2}=54 \mathrm{~L} \mathrm{~h}^{-1}$.

Tal comportamento pode indicar que acima de $10,0 \times 10^{-3} \mathrm{~mol} \mathrm{~L}^{-1}$ de $\mathrm{H}_{2} \mathrm{O}_{2}$ 
ocorre o consumo de peróxido de hidrogênio para formação de $\mathrm{HO}_{2}$, tendo-se, com isso, uma menor quantidade de radicais hidroxila para reagir a matéria orgânica $^{87}$.

\subsubsection{Influência da adição de metais em solução no processo de ozonização}

\subsection{Processo $\mathrm{O}_{3} / \mathrm{pH} 3 / \mathrm{Mn}^{2+}$}

Vários trabalhos ${ }^{59-61}$ mostraram que o uso de metais em solução apresenta uma melhora na mineralização da matéria orgânica. $\mathrm{Ni}$ e colaboradores $^{60}$ constataram que a presença de $1,00 \mathrm{mg} \mathrm{L}^{-1}$ de manganês acarretou um aumento da taxa de remoção de COT de 12,6 para $98 \%$ em 60 minutos de tratamento de uma solução de 2-clorofenol em pH 3.

No estudo apresentado na Figura 22, pode-se observar que a presença de manganês em uma concentração de $1,00 \times 10^{-5} \mathrm{~mol} \mathrm{~L}^{-1}$ durante a ozonização do azocorante modelo permitiu uma remoção de COT de $54 \%$ em 30 minutos de tratamento, proporcionando uma melhora de $64 \%$ se comparado com a mineralização obtida durante o mesmo tempo de tratamento com o processo $\mathrm{O}_{3} / \mathrm{pH}$. A razão de consumo observada na presença de $\mathrm{Mn}^{2+}$ foi significantemente inferior à obtida em sua ausência $\left(\mathrm{O}_{3} / \mathrm{pH} 3 / \mathrm{Mn}^{2+}: \mathrm{Q}_{\text {cons }}=2,5 \mathrm{e}\right.$ $\left.\mathrm{O}_{3} / \mathrm{pH} 3: \mathrm{Q}_{\text {cons }}=4,7\right)$. 


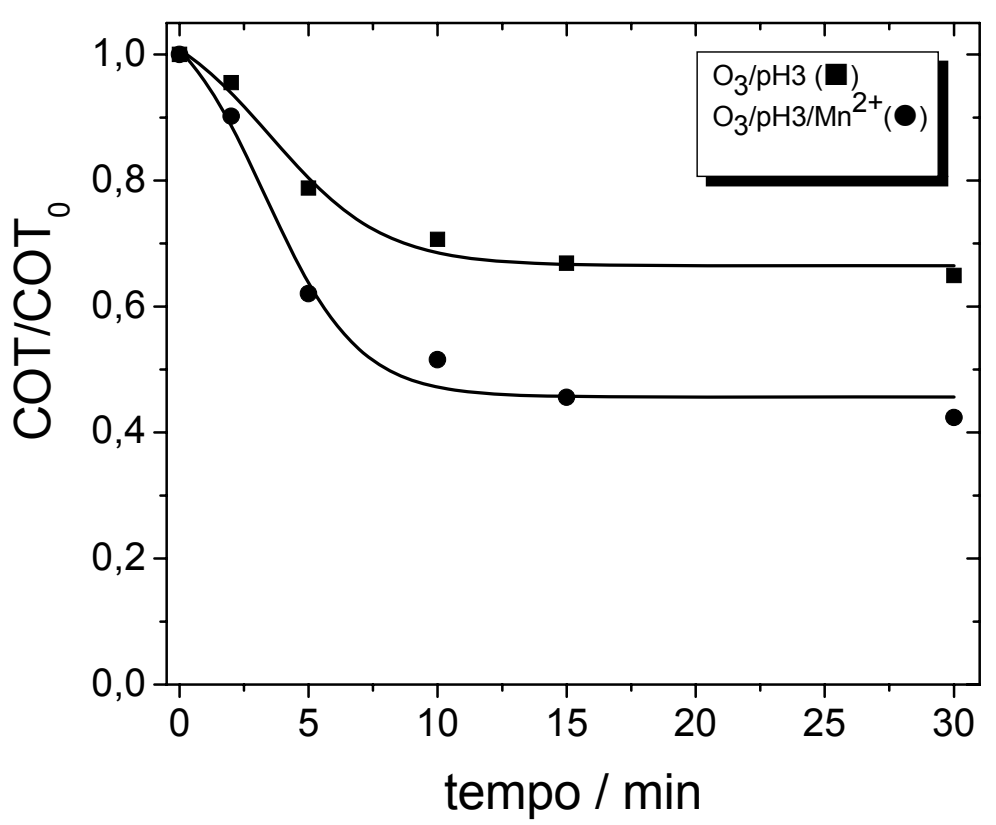

Figura 22. Variação da concentração de carbono orgânico total em função do tempo de ozonização de uma solução do corante Preto Remazol B na ausência e presença de uma concentração de $1,00 \times 10^{-5}$ mol L ${ }^{-1}$ de manganês. Condições experimentais: $\mathrm{pH}=3$; [corante $]_{0}=100$ $\mathrm{mg} \mathrm{L}^{-1}$; vazão de $\mathrm{O}_{2}=54 \mathrm{~L} \mathrm{~h}^{-1}$.

A presença de manganês na solução apresentou resultados promissores. Então, em uma etapa subseqüente, avaliou-se o efeito da concentração de manganês no processo de ozonização.

A Figura 23 mostra o grau de mineralização de uma solução do corante modelo em função da concentração de $\mathrm{Mn}^{2+}$ presente durante o processo de ozonização. Variando-se a concentração de $\mathrm{Mn}^{2+}$ entre $5,00 \times 10^{-6}$ e $1,00 \times 10^{-3}$ mol L $\mathrm{L}^{-1}$ observou-se que a eficiência do processo aumenta de forma exponencial em função da concentração do íon metálico, até atingir um patamar. 


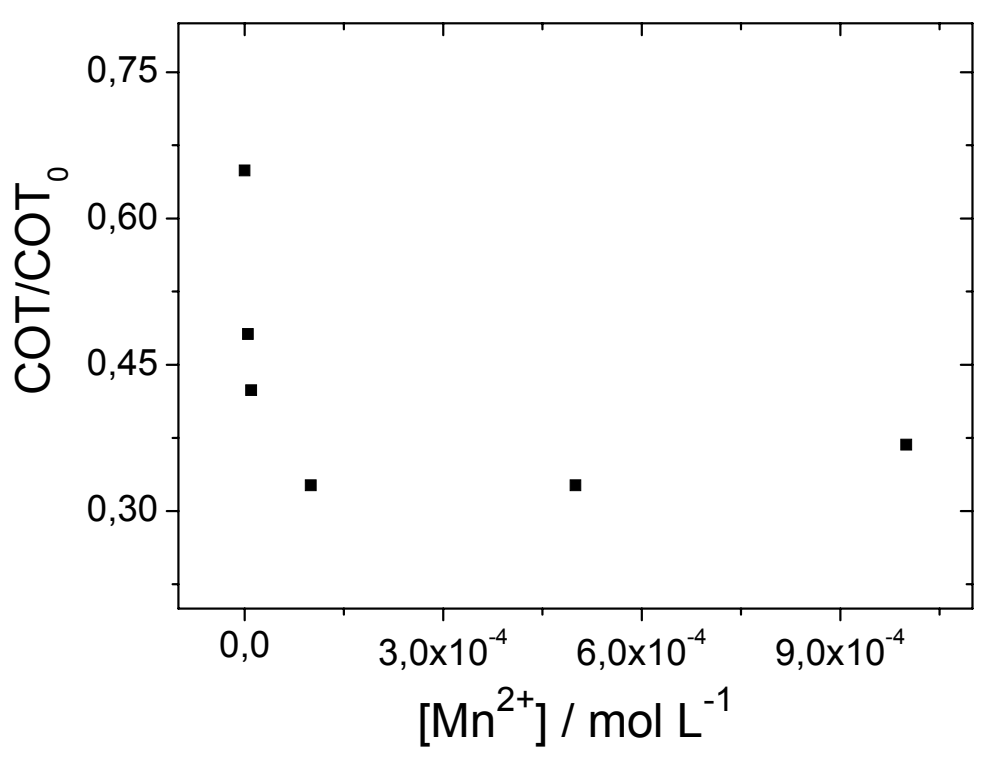

Figura 23. Variação da concentração do carbono orgânico total em função da concentração de manganês de uma solução do corante Preto Remazol B após 30 minutos de ozonização. Condições experimentais: $\mathrm{pH}=3$; [corante $]_{0}=100 \mathrm{mg} \mathrm{L}^{-1}$; vazão de $\mathrm{O}_{2}=54 \mathrm{~L} \mathrm{~h}^{-1}$.

Analisando-se a figura acima, pode-se perceber que ao se aumentar a concentração de manganês até $1,00 \times 10^{-4} \mathrm{~mol} \mathrm{~L}^{-1}$ houve um aumento na mineralização de $68 \%$ no tempo de 30 minutos proporcionando um ganho de 107\% na magnitude deste parâmetro quando comparado com a ozonização de uma solução do corante na ausência do íon metálico. Acima desta concentração se chegou a um patamar de mineralização e à formação crescente de dióxido de manganês. O efeito deste óxido sobre a remoção de COT do azocorante será apresentado no próximo item. 
As reações na presença de manganês apresentaram uma taxa de remoção de COT com comportamento similar à uma cinética de pseudo-primeira ordem, as constantes aparente de remoção estão apresentadas na Tabela 6.

Tabela 6. Variação das constantes aparentes de remoção de COT com a concentração de manganês.

\begin{tabular}{|c|c|}
\hline$\left[\mathrm{Mn}^{2+}\right] \mathrm{mol} \mathrm{L}^{-1}$ & $\mathrm{~K}_{\text {obs }}\left(\mathrm{min}^{-1}\right)$ \\
\hline-------- & $0,035 \pm 0,007$ \\
$5,00 \times 10^{-6}$ & $0,066 \pm 0,016$ \\
$1,00 \times 10^{-5}$ & $0,069 \pm 0,013$ \\
$5,00 \times 10^{-4}$ & $0,099 \pm 0,017$ \\
$1,00 \times 10^{-4}$ & $0,093 \pm 0,025$ \\
$1,00 \times 10^{-3}$ & $0,084 \pm 0,004$ \\
\hline
\end{tabular}

Comparando as constantes aparentes de remoção das diferentes concentrações de manganês, pode-se observar que mesmo no caso de uma concentração de $5,00 \times 10^{-6} \mathrm{~mol} \mathrm{~L}^{-1}$, que levou as menores taxas de mineralização, houve um aumento da velocidade da reação se comparado com o processo $\mathrm{O}_{3} / \mathrm{pH}$. Pode-se verificar que houve melhoras na velocidade da reação de até $188 \%$.

\subsection{Processo $\mathrm{O}_{3} / \mathrm{pH} 3 / \mathrm{MnO}_{2}$}

Em virtude da formação de dióxido de manganês no processo anterior, efetuou-se um estudo com o objetivo de avaliar o papel deste na ozonização do 
azocorante. A Figura 28 mostra que após 30 minutos de ozonização na presença de $\mathrm{MnO}_{2}$ houve uma melhora de $103 \%$ se comparado com os resultados apresentados pelo processo $\mathrm{O} 3 / \mathrm{pH} 3$.

Os valores obtidos são comparáveis com os apresentados pela mineralização usando uma concentração de $\mathrm{Mn}^{2+}$ igual a $1,00 \times 10^{-5} \mathrm{~mol} \mathrm{~L}^{-1}$.

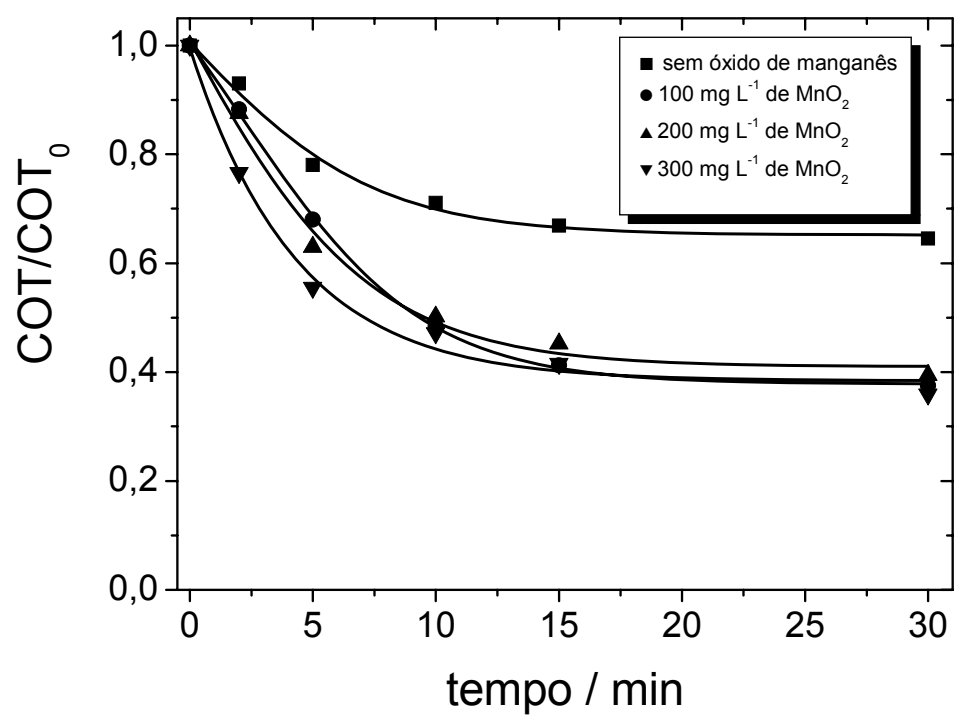

Figura 24. Variação da concentração do carbono orgânico total em função do tempo de ozonização de uma solução do corante Preto Remazol B em diferentes concentrações de óxido de manganês. Condições experimentais: $\mathrm{pH}=3$; [corante $]_{0}=100 \mathrm{mg} \mathrm{L}^{-1}$; vazão de $\mathrm{O}_{2}=$ $54 \mathrm{~L} \mathrm{~h}^{-1}$.

Segundo Ma e Graham ${ }^{54}$, o dióxido de manganês produzido na solução é devido à oxidação do manganês. $\mathrm{MnO}_{2}$ possui uma alta área superficial, a qual hidratada apresenta sítios ativos (por exemplo, grupos hidroxilas) que auxiliam a geração de radicais hidroxila e com isso o aumento do grau de mineralização. 
Dessa forma, pode-se inferir que $\mathrm{O} \mathrm{MnO}_{2}$ possui um papel importante no aumento da eficiência na mineralização do azocorante modelo, na faixa de concentração estudada.

\subsection{Efeito sinérgico da adição simultânea de íons manganês (II) e peróxido de hidrogênio em solução durante o processo de ozonização}

Conforme apresentado anteriormente, a presença de peróxido de hidrogênio ou de $\mathrm{Mn}^{2+}$ em solução provocou uma melhora na mineralização do azocorante modelo pelo processo de ozonização em meio ácido. Assim realizouse um estudo em que se empregaram ambas as espécies simultaneamente, visando avaliar se haveria um efeito sinérgico durante a ozonização do corante.

Na Figura 25 é apresentada a mineralização do corante Preto Remazol B em função do tempo de tratamento pelos processos $\mathrm{O}_{3} / \mathrm{pH} 3 / \mathrm{Mn}^{2+}, \mathrm{O}_{3} / \mathrm{pH}_{3} / \mathrm{H}_{2} \mathrm{O}_{2} \mathrm{e}$ $\mathrm{O}_{3} / \mathrm{pH}_{3} / \mathrm{Mn}^{2+} / \mathrm{H}_{2} \mathrm{O}_{2}$. Na presença de manganês e de $\mathrm{H}_{2} \mathrm{O}_{2}$ houve uma melhora de 167\% se comparado com o processo de ozonização na ausência ambos.

Diversos trabalhos mostram que na presença de alguns metais de transição o peróxido de hidrogênio pode dar origem a espécies radicalares (principalmente o radical hidroxila) via reações do tipo Fenton ${ }^{88-90}$. A fim de verificar a ação do ozônio no processo $\mathrm{O}_{3} / \mathrm{pH}_{3} / \mathrm{Mn}^{2+} / \mathrm{H}_{2} \mathrm{O}_{2}$, realizou-se um experimento comparativo passando-se somente oxigênio pelo reator contendo uma solução do corante $(\mathrm{em} \mathrm{pH}=3)$ e $1,00 \times 10^{-5} \mathrm{~mol} \mathrm{~L}^{-1}$ de $\mathrm{Mn}^{2+}$ e $5,00 \times 10^{-3}$ mol L-1 de $\mathrm{H}_{2} \mathrm{O}_{2}$. A geração de espécies oxidantes a partir da interação $\mathrm{Mn}^{2+} / \mathrm{H}_{2} \mathrm{O}_{2}$ não foi observada nestas condições, uma vez que não se verificou nenhuma alteração na concentração de COT durante 30 minutos de reação. Tal resultado 
indica que o ozônio possui um papel fundamental na eficiência do processo $\mathrm{O}_{3} / \mathrm{pH}_{3} / \mathrm{Mn}^{2+} / \mathrm{H}_{2} \mathrm{O}_{2}$.

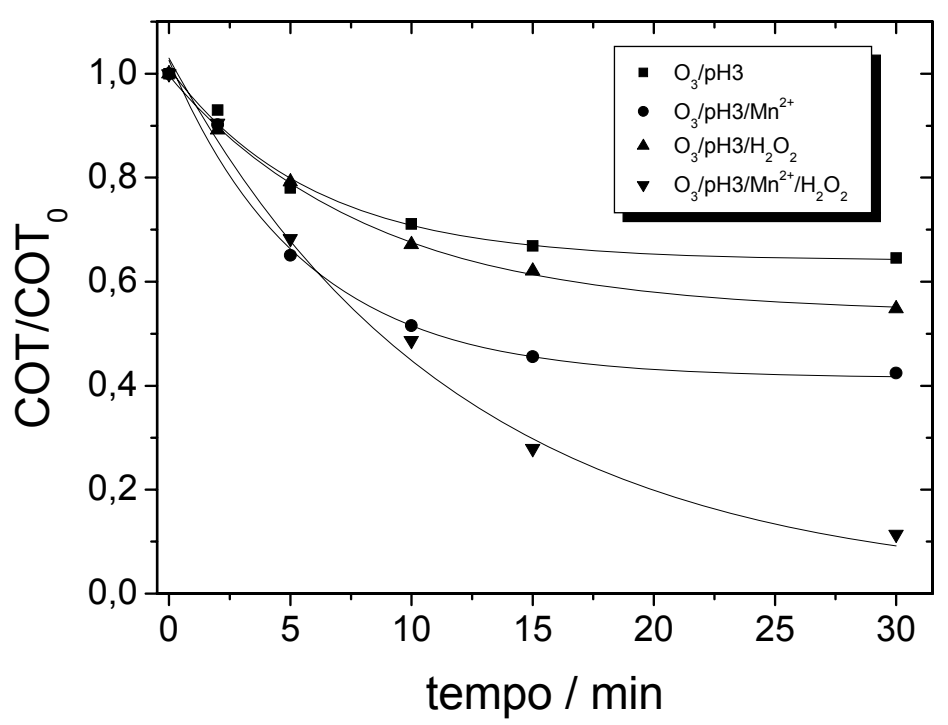

Figura 25. Variação da concentração de carbono orgânico total de uma solução $100 \mathrm{mg} \mathrm{L}^{-1}$ do corante Preto Remazol B durante a ozonização em pH 3 sem (•) e com a na presença de $1,00 \times 10^{-5} \mathrm{~mol} \mathrm{~L}^{-1}$ de $\mathrm{Mn}^{2+}(\bullet)$; $5,00 \times 10^{-3} \mathrm{~mol} \mathrm{~L}^{-1}$ de $\mathrm{H}_{2} \mathrm{O}_{2}(\boldsymbol{\Delta})$ e $1,00 \times 10^{-5} \mathrm{~mol} \mathrm{~L}^{-1} \mathrm{Mn}^{2+} / 5 \times 10^{-3} \mathrm{~mol} \mathrm{~L}^{-1}$ $\mathrm{H}_{2} \mathrm{O}_{2}(\boldsymbol{\nabla})$. Condições experimentais: $\mathrm{pH}=3$; [corante] $]_{0}=100 \mathrm{mg} \mathrm{L}^{-1}$; vazão de $\mathrm{O}_{2}=54 \mathrm{~L} \mathrm{~h}^{-1}$.

Após esta etapa, foi realizado uma avaliação exploratória do efeito da concentração de íons manganês(II) e de peróxido de hidrogênio no meio reacional. Foram escolhidas 3 concentrações de cada espécie: $\left[\mathrm{H}_{2} \mathrm{O}_{2}\right]=1,00$; 5,00 e $10,00 \times 10^{-3} \mathrm{~mol} \mathrm{~L}^{-1}$ e $\left[\mathrm{Mn}^{2+}\right]=10,00 ; 1,00$ e $10,0 \times 10^{-5} \mathrm{~mol} \mathrm{~L}^{-1}$.

Para uma concentração de $\mathrm{Mn}^{2+}$ igual a $10,00 \times 10^{-5} \mathrm{~mol} \mathrm{~L}^{-1}$, o melhor resultado de mineralização foi obtido empregando-se $1,00 \times 10^{-3} \mathrm{~mol} \mathrm{~L}^{-1} \mathrm{de}$ peróxido de hidrogênio. Nestas condições, observou-se uma remoção de COT de 79\% (Figura 26). 


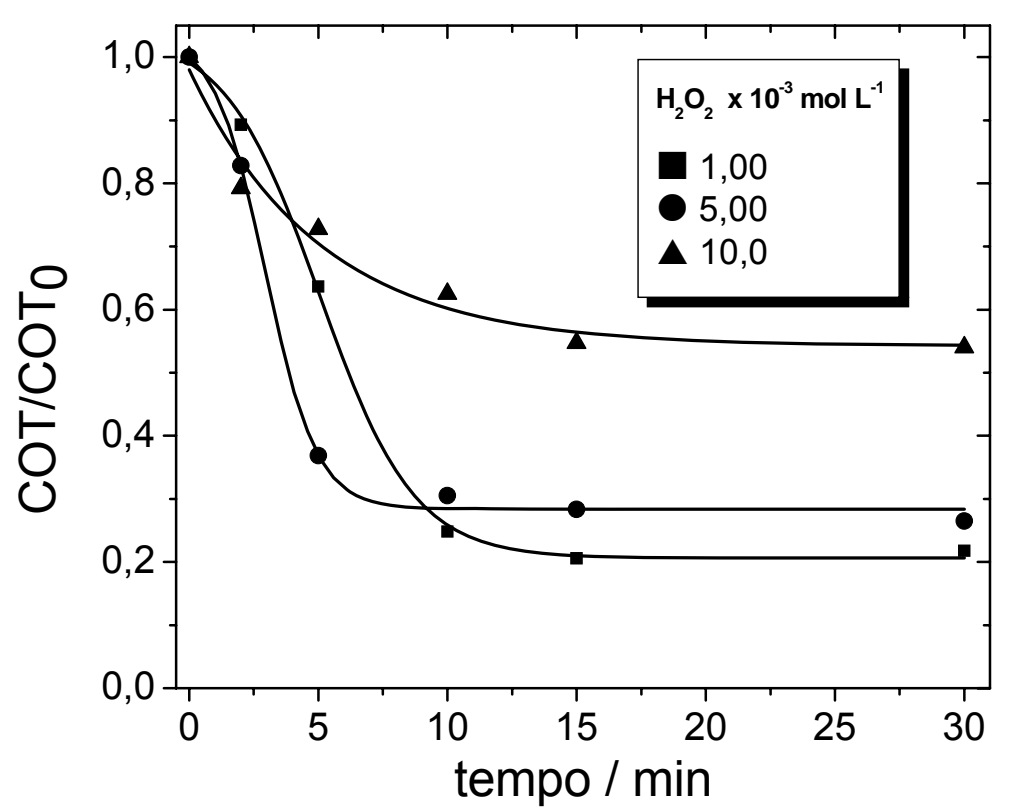

Figura 26. Variação da concentração de carbono orgânico total em função do tempo de ozonização de uma solução do corante Preto Remazol B empregando-se $1,00 \times 10^{-4} \mathrm{~mol} \mathrm{~L}^{-1}$ de $\mathrm{Mn}^{2+}$ e diferentes concentrações de $\mathrm{H}_{2} \mathrm{O}_{2}$. Condições experimentais: $\mathrm{pH}=3$; [corante] $]_{0}=$ $100 \mathrm{mg} \mathrm{L}^{-1}$; vazão de $\mathrm{O}_{2}=54 \mathrm{~L} \mathrm{~h}^{-1}$.

Na Tabela 7 são apresentadas às porcentagens de mineralização após 30 minutos de ozonização, nas várias condições estudadas. O maior grau de mineralização foi obtido empregando-se $1,00 \times 10^{-5} \mathrm{~mol} \mathrm{~L}^{-1}$ de $\mathrm{Mn}^{2+}$ e $5,00 \times 10^{-3}$ mol L ${ }^{-1}$ de $\mathrm{H}_{2} \mathrm{O}_{2}$. Nesta combinação obteve-se aproximadamente $89 \%$ de remoção da matéria orgânica.

Em todas as condições estudadas, observou-se uma taxa de remoção de COT com comportamento similar ao de pseudo-primeira ordem, sendo as constantes aparente de remoção apresentadas na Tabela 8. 
Mais uma vez, a combinação de $1,00 \times 10^{-5} \mathrm{~mol} \mathrm{~L}^{-1}$ de $\mathrm{Mn}^{2+} \mathrm{com}$ $1,00 \times 10^{-3} \mathrm{~mol} \mathrm{~L}^{-1}$ de $\mathrm{H}_{2} \mathrm{O}_{2}$ foi a que apresentou a maior velocidade de remoção de COT.

Tabela 7. Porcentagem de remoção de carbono orgânico total em função da concentração de peróxido de hidrogênio e de manganês após 30 minutos de ozonização.

\begin{tabular}{|c|ccc|}
\cline { 2 - 4 } \multicolumn{1}{c|}{} & \multicolumn{3}{c|}{ \% Mineralização } \\
\hline$\left[\mathrm{Mn}^{2+}\right] \times 10^{-5} \mathrm{~mol} \mathrm{~L}^{-1}$ & \multicolumn{3}{c|}{$\left[\mathrm{H}_{2} \mathrm{O}_{2}\right] \times 10^{-3} \mathrm{~mol} \mathrm{~L}^{-1}$} \\
& $\mathbf{1 , 0 0}$ & $\mathbf{5 , 0 0}$ & $\mathbf{1 0 , 0}$ \\
\hline $\mathbf{1 0 , 0 0}$ & 79 & 74 & 46 \\
$\mathbf{1 , 0 0}$ & 81 & 89 & 48 \\
$\mathbf{0 , 1 0}$ & 69 & 83 & 73 \\
\hline
\end{tabular}

Tabela 8. Variação da taxa de mineralização em função da concentração de íon manganês (II) e de peróxido no processo $\mathrm{O}_{3} / \mathrm{pH} 3 / \mathrm{Mn}^{2+} / \mathrm{H}_{2} \mathrm{O}_{2}$.

\begin{tabular}{|c|ccc|}
\cline { 2 - 4 } \multicolumn{1}{c|}{} & \multicolumn{3}{|c|}{$\mathbf{k}_{\text {obs }} / \mathbf{m i n}^{-1}$} \\
\hline$\left[\mathrm{Mn}^{2+}\right] \times 10^{-5} \mathrm{~mol} \mathrm{~L}^{-1}$ & $\mathbf{1 , 0 0}$ & $\left.\mathbf{\mathrm { H } _ { 2 }}\right] \times \mathbf{1 0}^{-3} \mathrm{~mol} \mathrm{~L}^{-1}$ \\
& & $\mathbf{5 , 0 0}$ & $\mathbf{1 0 , 0 0}$ \\
\hline $\mathbf{1 0 , 0 0}$ & $0,143 \pm 0,020$ & $0,126 \pm 0,033$ & $0,043 \pm 0,011$ \\
$\mathbf{1 , 0 0}$ & $0,155 \pm 0,024$ & $0,074 \pm 0,004$ & $0,049 \pm 0,005$ \\
$\mathbf{0 , 1 0}$ & $0,038 \pm 0,006$ & $0,052 \pm 0,006$ & $0,043 \pm 0,002$ \\
\hline
\end{tabular}




\subsection{Processo $\mathrm{O}_{3} / \mathrm{pH} 3 / \mathrm{Fe}^{3+}$}

Outro metal que tem demonstrado capacidade de mineralizar compostos orgânicos ao ser associado com o ozônio é o ferro. Segundo Canton e colaboradores $^{90}$, a presença de íons ferro(III) em solução provoca uma melhora na mineralização. Já segundo Sauleda e colaboradores ${ }^{47}$ esta melhora pode ser obtida empregando-se íons ferro(II). Afim a avaliar o efeito de ambos os estados de oxidação do ferro no presente trabalho foi realizado um estudo comparativo.

Na Figura 27 pode-se observar a mineralização de diferentes soluções do azocorante contendo uma mesma concentração de ferro(II) e de ferro(III) em função do tempo de ozonização.

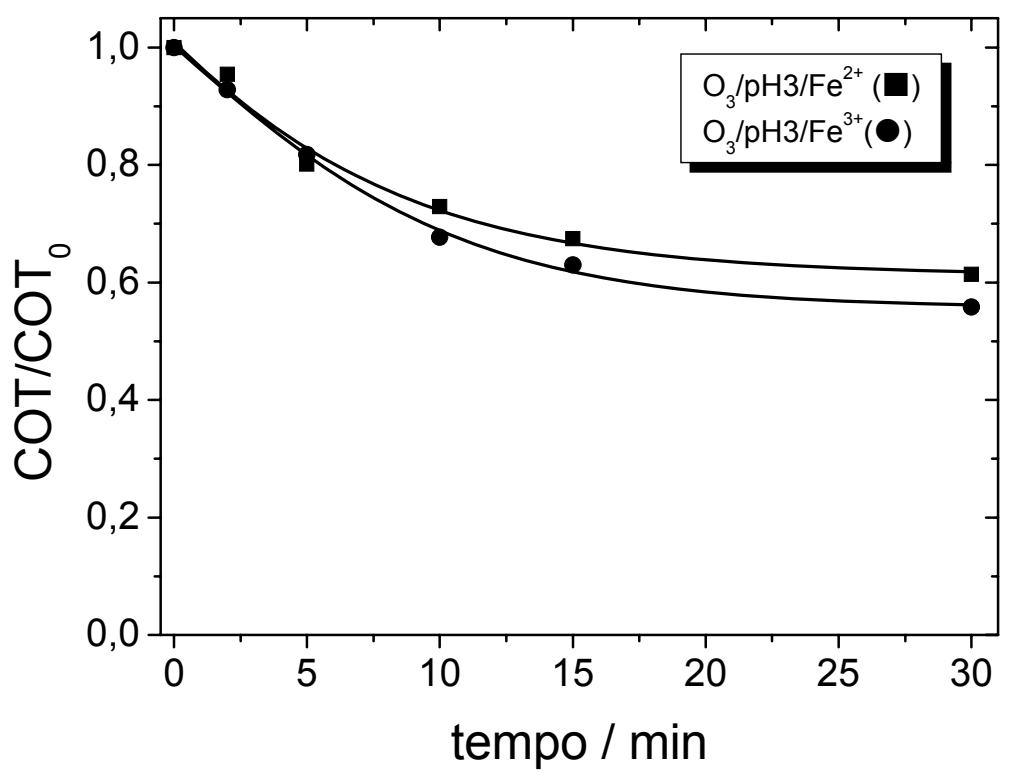

Figura 27. Variação da concentração do carbono orgânico total em função da concentração de ferro(II) e de ferro(III) de uma solução do corante Preto Remazol B após $30 \mathrm{~min}$ de ozonização. Condições experimentais: $\mathrm{pH}=3$; [corante] $]_{0}=100 \mathrm{mg} \mathrm{L}^{-1}$; vazão de $\mathrm{O}_{2}=54 \mathrm{~L} \mathrm{~h}^{-1}$. 
Comparando-se os dois sistemas, pode-se observar que há uma ligeira superioridade no grau de mineralização para soluções contendo ferro(III). Baseado na similaridade dos resultados de remoção de COT do corante, e que nas condições oxidantes do meio o ferro(II) é rapidamente oxidado a $\mathrm{Fe}$ (III), supõe-se que o ferro (III) seja a espécie responsável por catalisar a decomposição do ozônio em ambos os sistemas estudados. Desta forma, os demais estudos sobre a influência de ferro no processo de ozonização foram realizados empregando-se soluções de ferro(III).

A Figura 28 mostra a mineralização do azocorante modelo empregando-se os processos $\mathrm{O}_{3} / \mathrm{pH}$ e $\mathrm{e}_{3} / \mathrm{pH}_{3} / \mathrm{Fe}^{3+}$.

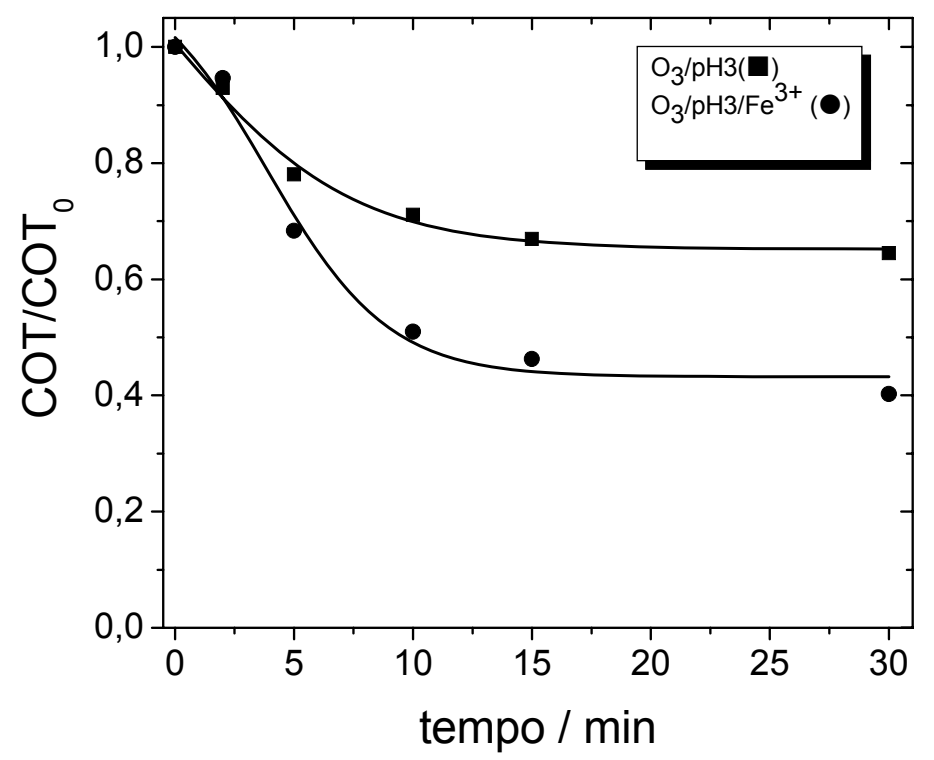

Figura 28. Variação da concentração do carbono orgânico total em função do tempo de ozonização de uma solução do corante Preto Remazol B na presença de uma concentração de $1,00 \times 10^{-4} \mathrm{~mol} \mathrm{~L}^{-1}$ ferro(III). Condições experimentais: $\mathrm{pH}=3$; [corante $]_{0}=100 \mathrm{mg} \mathrm{L}^{-1}$; vazão de $\mathrm{O}_{2}=54 \mathrm{~L} \mathrm{~h}^{-1}$. 
Comparando-se estes tratamentos, pode-se verificar que na presença de ferro(III) houve uma melhora de $70 \%$ após 15 minutos de ozonização sendo que a grau de mineralização não se altera para tempos maiores de tratamento. A razão de consumo de ozônio obtida para o processo $\mathrm{O}_{3} / \mathrm{pH}_{3} / \mathrm{Fe}^{3+}$ foi de 3,2 ; este valor é menor do que o valor apresentado pelo tratamento sem a presença de $\mathrm{Fe}^{3+}\left(\mathrm{Q}_{\text {cons }}\right.$ $=4,7)$ mostrando, assim, que mantendo-se os demais condições experimentais, quando emprega-se o processo $\mathrm{O}_{3} / \mathrm{pH}_{3} / \mathrm{Fe}^{3+}$ têm-se um menor consumo de ozônio para obter o mesmo grau de mineralização.

Como etapa subseqüente avaliou-se o efeito da concentração de ferro(III) no processo de ozonização (Figura 29).

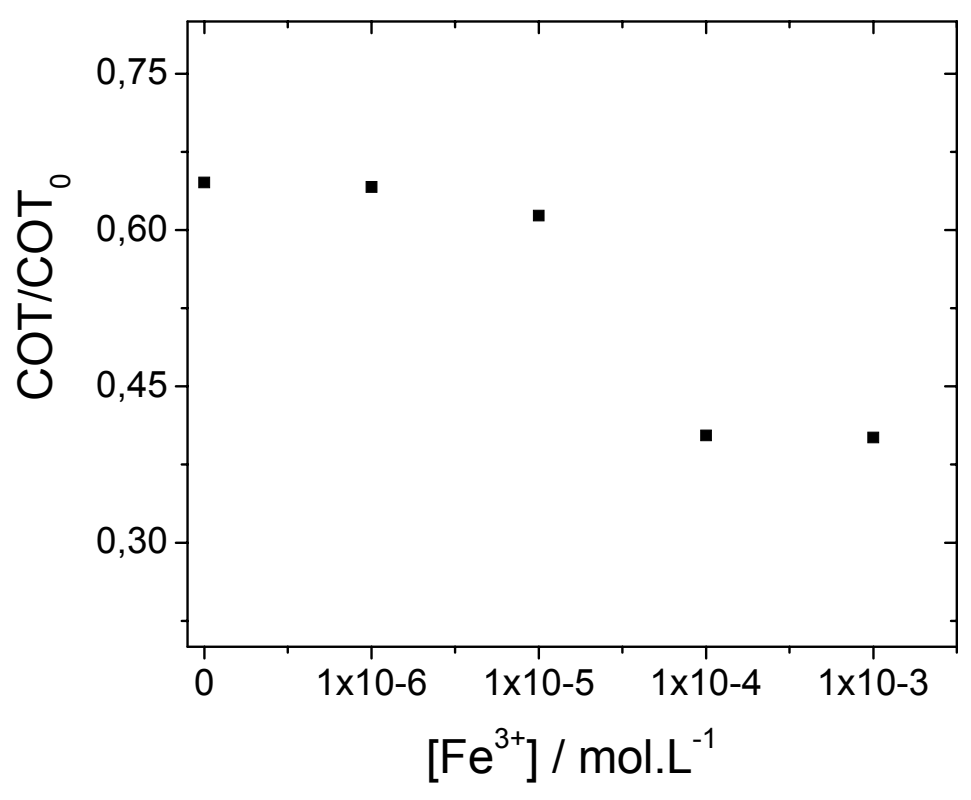

Figura 29. Variação da concentração do carbono orgânico total em função da concentração de ferro(III) de uma solução do corante Preto Remazol B após 30 min de processo. Condições experimentais: $\mathrm{pH}=3$; [corante $]_{0}=100 \mathrm{mg} \mathrm{L}^{-1}$; vazão de $\mathrm{O}_{2}=54 \mathrm{~L} \mathrm{~h}^{-1}$. 
Nesta figura pode-se observar que em 30 minutos de ozonização, adicionando-se até $1,00 \times 10^{-5} \mathrm{~mol} \mathrm{~L}^{-1}$ de ferro (III) houve somente uma ligeira melhora na mineralização. No entanto, adicionando uma concentração de 1,00 x $10^{-4} \mathrm{~mol} \mathrm{~L}^{-1}$ de ferro (III) o grau de mineralização aumentou para $60 \%$, apresentando uma melhora de $50 \%$ se comparado com o processo $\mathrm{O}_{3} / \mathrm{pH}$. Esta melhora não foi incrementada com o aumento da concentração do ferro para $1,00 \times 10^{-3} \mathrm{~mol} \mathrm{~L}^{-1}$

A reação na presença tanto de ferro (II) quanto de ferro (III) apresentou uma taxa de remoção de COT com comportamento similar ao de pseudo primeira ordem, as constantes aparente de remoção estão apresentadas na Tabela 9. A semelhança nos valores das constantes aparente de remoção, considerando-se os erros, corrobora com a hipótese de formação da mesma espécie em ambos os casos.

Tabela 9. Efeito da concentração de ferro (II) e ferro (III) na variação da constante aparente de remoção de COT e na mineralização em 30 minutos de tratamento.

\begin{tabular}{|c|c|c|c|c|}
\hline \multirow[b]{2}{*}{ [ Ferro] mol.L ${ }^{-1}$} & \multicolumn{2}{|c|}{$\mathrm{Fe}^{2+}$} & \multicolumn{2}{|c|}{$\mathrm{Fe}^{3+}$} \\
\hline & $\mathrm{k}_{\text {obs }}$ & $\overline{{\text { COT} / C^{-}}}$ & $\mathrm{k}_{\text {obs }}$ & $\overline{\mathrm{COT} / \mathrm{COT}_{0}}$ \\
\hline & $0,035 \pm 0,007$ & 0,33 & $0,035 \pm 0,007$ & 0,33 \\
\hline $1,00 \times 10^{-6}$ & $0,035 \pm 0,009$ & 0,42 & $0,044 \pm 0,006$ & 0,34 \\
\hline $1,00 \times 10^{-5}$ & $0,033 \pm 0,006$ & 0,44 & $0,039 \pm 0,006$ & 0,38 \\
\hline $1,00 \times 10^{-4}$ & $0,071 \pm 0,008$ & 0,57 & $0,062 \pm 0,009$ & 0,60 \\
\hline $1,00 \times 10^{-3}$ & $0,080 \pm 0,015$ & 0,64 & $0,083 \pm 0,008$ & 0,60 \\
\hline
\end{tabular}




\subsection{Análise comparativa dos diferentes processos}

A Tabela 10 mostra a variação de $k_{\text {obs, }} Q_{\text {cons }}$ e a porcentagem de mineralização para os diferentes processos aplicados ao azocorante modelo.

Tabela 10. Variação de $k_{\text {obs }}, Q_{\text {cons }}$ e a \% mineralização para os diferentes métodos aplicados ao azocorante modelo.

\begin{tabular}{|c|c|c|c|}
\hline Processo & $k_{\text {obs }}\left(\min ^{-1}\right)$ & $Q_{\text {cons }}$ & \% mineralização \\
\hline $\mathrm{O}_{3} / \mathrm{pH} 3$ & 0,035 & 4,7 & 35 \\
\hline $\mathrm{O}_{3} / \mathrm{pH} 11$ & 0,067 & 3,0 & 57 \\
\hline $\mathrm{O}_{3} / \mathrm{pH} 3 / \mathrm{H}_{2} \mathrm{O}_{2}$ & 0,038 & 4,0 & 50 \\
\hline $\mathrm{O}_{3} / \mathrm{pH} 3 / \mathrm{Mn}^{2+}$ & 0,093 & 2,5 & 68 \\
\hline $\mathrm{O}_{3} / \mathrm{pH} 3 / \mathrm{H}_{2} \mathrm{O}_{2} / \mathrm{Mn}^{2+}$ & 0,074 & 6,1 & 89 \\
\hline $\mathrm{O}_{3} / \mathrm{pH} 3 / \mathrm{Fe}^{3+}$ & 0,062 & 3,2 & 60 \\
\hline $\mathrm{O}_{3} / \mathrm{pH}_{3} / \mathrm{MnO}_{2}$ & 0,074 & 2,4 & 63 \\
\hline
\end{tabular}

A presença de peróxido de hidrogênio e/ou de íons metálicos $\left(\mathrm{Mn}^{2+}\right.$ e $\left.\mathrm{Fe}^{3+}\right)$ proporcionou um acréscimo tanto para as taxas quanto para a porcentagem de mineralização (comparando-se com o processo $\mathrm{O}_{3} / \mathrm{pH} 3$ ). No caso do consumo de ozônio, houve um decréscimo em todos os tratamentos estudados com exceção do processo combinado $\mathrm{O}_{3} / \mathrm{pH}_{3} / \mathrm{H}_{2} \mathrm{O}_{2} / \mathrm{Mn}^{2+}$, o qual, por outro lado, apresentou as maiores taxas de remoção.

O processo $\mathrm{O}_{3} / \mathrm{pH}_{3} / \mathrm{Mn}^{2+}$ apresentou a maior constante aparente de remoção $\left(k_{\text {obs }}=0,093 \mathrm{~min}^{-1}\right)$ e a menor razão de consumo $\left(Q_{\text {cons }}=2,5\right)$ apresentando-se como o melhor tratamento quando se busca uma otimização do tempo e da quantidade de ozônio aplicado. Por outro lado, o processo $\mathrm{O}_{3} / \mathrm{pH}_{3} / \mathrm{H}_{2} \mathrm{O}_{2} / \mathrm{Mn}^{2+}$ apresenta-se como uma boa alternativa quando se busca um maior grau de remoção. 


\subsubsection{Ozonização dos corantes Azul Remazol Brilhante RN e Turquesa Remazol G 133}

Os processos que apresentaram os melhores resultados de mineralização foram aplicados a outros dois corantes: Azul Remazol Brilhante RN e Turquesa Remazol G133.

\subsubsection{Degradação dos corantes}

Em todos os processos de ozonização, com ou sem catalisador, houve uma degradação rápida dos corantes, o que pode ser observado nos espectros UV-Vis apresentados na Figura 30.

Pode-se verificar, que em menos 2 minutos de tratamento ocorre a completa destruição do grupo cromóforo, isto é confirmado através do desaparecimento das bandas em 595, $625 \mathrm{~nm}$ no caso do Remazol Brilhante RN e da banda em 625 nm no caso do Turquesa Remazol G133.
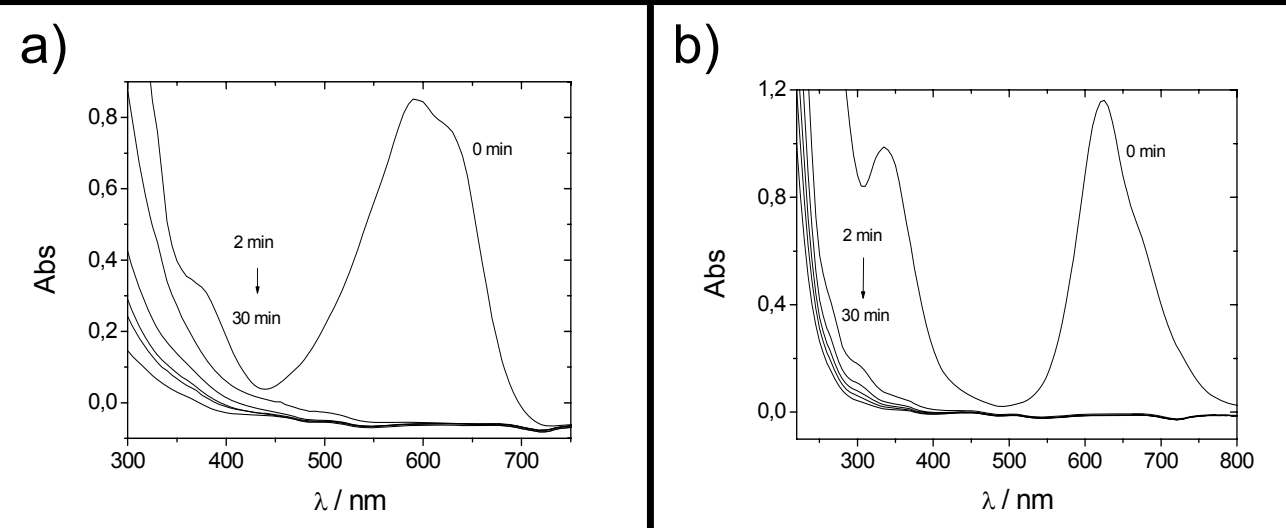

Figura 30. Espectro UV-Vis de uma solução do corante Azul Remazol Brilhante RN (a) Turquesa Remazol (b) após diferentes tempos de ozonização. Condições experimentais: $\mathrm{pH}=3$; [corante] $]_{0}=100 \mathrm{mg} \mathrm{L}^{-1}$; 
vazão de $\mathrm{O}_{2}=54 \mathrm{~L} \mathrm{~h}^{-1}$.

\subsubsection{Mineralização dos corantes}

Como pode ser observado na Figura 31 no caso corante Azul Remazol Brilhante $\mathrm{RN}$, o processo $\mathrm{O}_{3} / \mathrm{pH} 3$ apresentou uma mineralização em torno de 40\%. Na presença de $\mathrm{H}_{2} \mathrm{O}_{2}$ não se observou nenhuma melhora significativa e a presença de manganês apresentou o melhor resultado, obtendo-se uma mineralização em torno de $78 \%$, levando, assim, a uma melhora de $95 \%$.

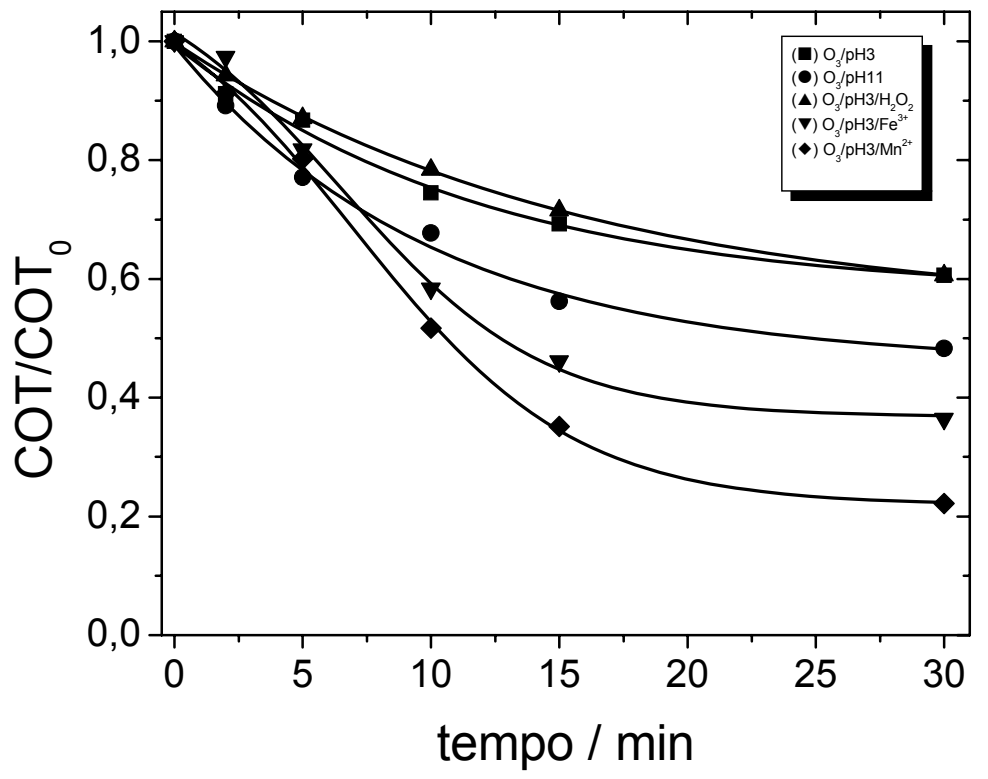

Figura 31. Variação da concentração do carbono orgânico total em função do tempo de ozonização de uma solução do corante Azul Remazol Brilhante RN usando diferentes métodos de ozonização. Condições experimentais: $\mathrm{pH}=3$; [corante $]_{0}=100 \mathrm{mg} \mathrm{L}^{-1}$; vazão de $\mathrm{O}_{2}=$ $54 \mathrm{~L} \mathrm{~h}^{-1}$.

A Figura 32 mostra que no caso do corante Turquesa Remazol G133, o processo $\mathrm{O}_{3} / \mathrm{pH} 3$ apresentou uma mineralização em torno $30 \%$. O melhor resultado obtido foi com o ensaio realizado em meio básico $\left(\mathrm{O}_{3} / \mathrm{pH} 11\right)$, em que se 
observou uma melhora de $170 \%$. A presença de $\mathrm{H}_{2} \mathrm{O}_{2}$ durante a ozonização ocasionou uma mineralização de aproximadamente 51\% (melhora de 63\% comparando-se com $\left.\mathrm{O}_{3} / \mathrm{pH} 3\right)$. O emprego de metais $\left(\mathrm{Mn}^{2+}\right.$ e $\left.\mathrm{Fe}^{3+}\right)$ em solução apresentou taxas de remoção de COT comparáveis com as obtidas na presença de $\mathrm{H}_{2} \mathrm{O}_{2}$. Ao contrário do observado durante a mineralização dos demais corantes, neste caso a presença dos metais $\left(\mathrm{Fe}^{3+}\right.$ e $\left.\mathrm{Mn}^{2+}\right)$ no meio reacional não foi tão significativa no aumento da remoção de matéria orgânica do corante Turquesa Remazol G133.

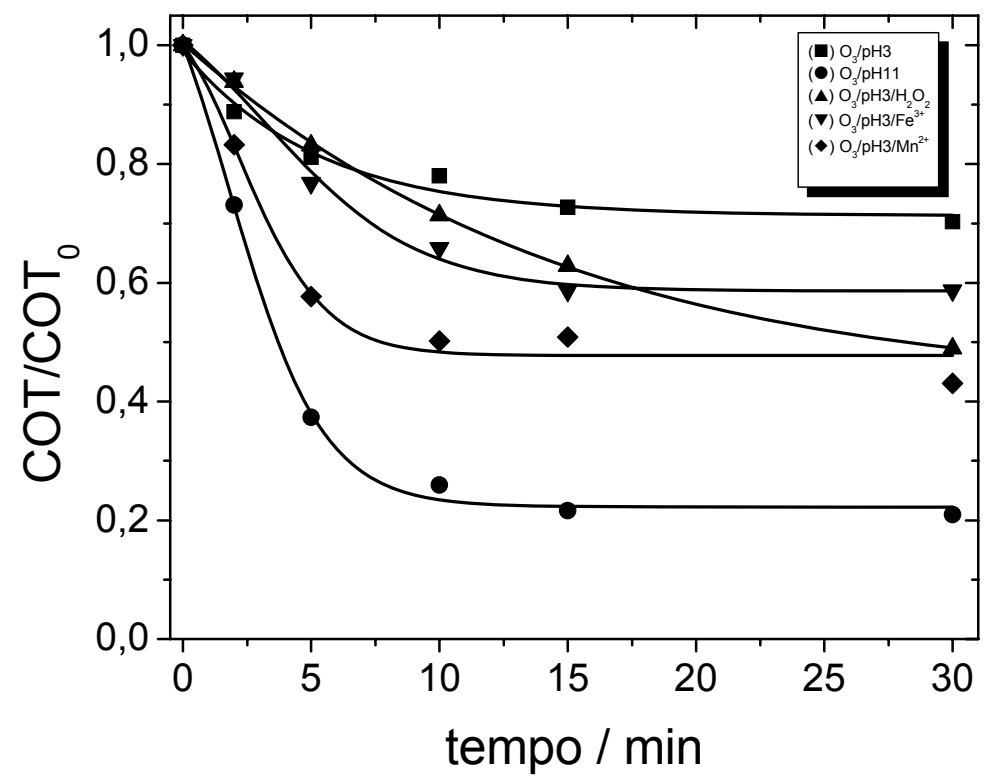

Figura 32. Variação da concentração do carbono orgânico total em função do tempo de ozonização de uma solução do corante Turquesa Remazol G133 usando diferentes processos de ozonização. Condições experimentais: $\mathrm{pH}=3$; [corante] $]_{0}=100 \mathrm{mg} \mathrm{L}^{-1}$; vazão de $\mathrm{O}_{2}=54 \mathrm{~L} \mathrm{~h}^{-1}$.

Todos os processos apresentaram uma taxa de remoção de COT com comportamento similar a de uma reação de pseudo-primeira ordem e as 
constantes aparente de remoção estão apresentadas na Tabela 11.

Tabela 11. Variação da constante aparente de remoção de COT para os corantes Azul Brilhante RN e Turqueza Remazol G133 com o método de ozonização empregado.

\begin{tabular}{|c|cc|}
\hline \multirow{2}{*}{ Método } & \multicolumn{2}{|c|}{$\mathbf{k}_{\text {obs }} I \mathbf{m i n}^{-1}$} \\
\cline { 2 - 3 } & Azul Remazol RN & Turquesa Remazol G133 \\
\hline $\mathbf{O}_{3} / \mathbf{p H 3}$ & $0,028 \pm 0,003$ & $0,023 \pm 0,007$ \\
$\mathbf{O}_{3} / \mathbf{p H 1 1}$ & $0,038 \pm 0,005$ & $0,137 \pm 0,024$ \\
$\mathbf{O}_{3} / \mathbf{p H} 3 / \mathrm{H}_{2} \mathbf{O}_{2}$ & $0,024 \pm 0,001$ & $0,034 \pm 0,001$ \\
$\mathbf{O}_{3} / \mathbf{p H} 3 / \mathrm{Mn}^{2+}$ & $0,066 \pm 0,008$ & $0,070 \pm 0,016$ \\
$\mathbf{O}_{3} / \mathbf{p H} 3 / \mathrm{Fe}^{2+}$ & $0,056 \pm 0,007$ & $0,044 \pm 0,005$ \\
\hline
\end{tabular}

Na Figura 33 tem-se, de uma forma resumida, a comparação dos diferentes tratamentos aplicados aos três corantes estudados.

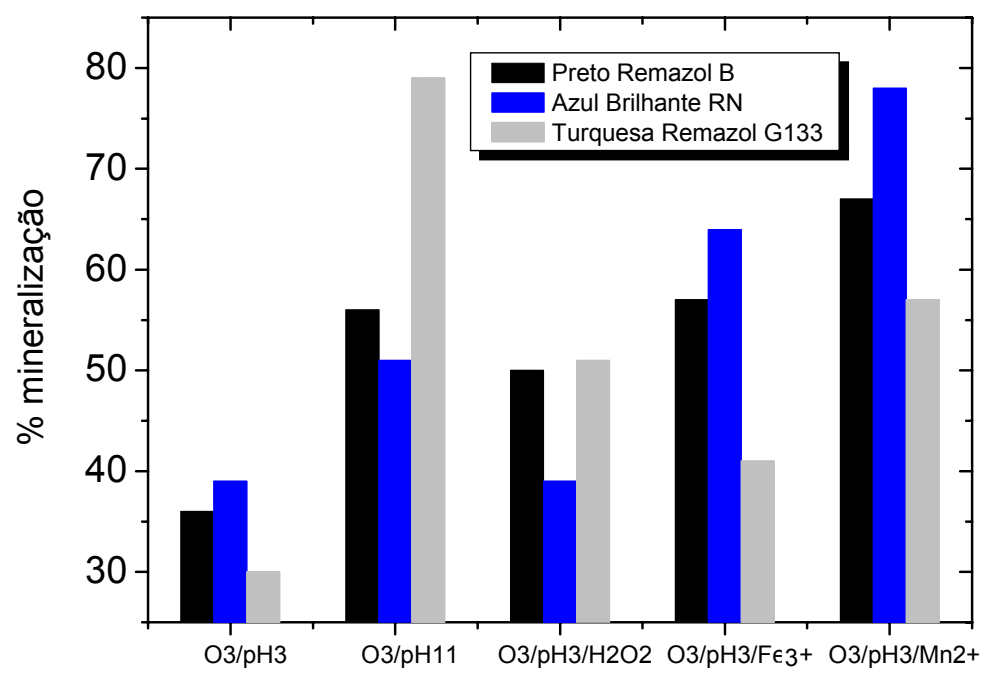

Figura 33. Resultados da porcentagem da variação da concentração do carbono orgânico total após 30 minutos de ozonização de uma solução de corante nos diferentes processos em estudo. Condições experimentais: $\mathrm{pH}=3$; [corante $]_{0}=100 \mathrm{mg} \mathrm{L}^{-1}$; vazão de $\mathrm{O}_{2}=54 \mathrm{~L} \mathrm{~h}^{-1}$. 
Conforme constatado anteriormente, tanto a adição de peróxido de hidrogênio como de íons metálicos em solução ocasionou uma melhora na eficiência do processo de ozonização para o Remazol Preto B. Este mesmo comportamento é seguido pelos outros corantes, exceto no caso do Turquesa Remazol G133 em meio básico. Há uma tendência crescente nas porcentagens de mineralização que segue a ordem: peróxido de hidrogênio < ferro < manganês. Os todos os casos, o manganês apresenta com as melhores taxas de remoção de COT.

\subsection{Ozonização de um efluente têxtil}

Após efetuar o estudo com os diferentes corantes, buscou-se aplicar o processo de ozonização em uma amostra oriunda de uma indústria têxtil. Conforme descrito no item 3.1, o efluente reúne o descarte líquido dos processos de lavagem, alvejamento e tingimento de tecidos da indústria têxtil. Este efluente possui alta carga de matéria orgânica o que pode ser confirmado através do resultado da análise de DQO $\left(2.234 \mathrm{mgo} \mathrm{L}^{-1}\right)$.

Nos testes preliminares realizados, aplicados ao efluente, deparou-se com algumas dificuldades para execução da ozonização, devido à alta formação de espuma quando é iniciado o processo de borbulhamento da mistura gasosa. A fim de contornar este problema buscou-se o emprego de álcoois, emulsões e siliconas com o intuito de minimizar a formação de espuma. Porém, todos os compostos testados foram ineficientes frente ao controle do problema, havendo a necessidade de se buscar outra alternativa. Uma delas foi efetuar uma filtração prévia do efluente. Efetuou-se a filtração de duas maneiras: a primeira 
empregando-se o método tradicional, ou seja, filtração sob a ação da gravidade utilizando papel filtro (porosidade: $14 \mu \mathrm{m}$ ), a segunda sob vácuo utilizando uma membrana de acetato de celulose (porosidade: $0,45 \mu \mathrm{m}$ ). No primeiro caso 0 problema persistiu, já utilizando o segundo método empregado ocorre a descoloração do efluente, perdendo assim suas características iniciais comprometendo assim o objetivo inicial do presente trabalho. Assim devido a todos os problemas apresentados, os processos estudados não puderam ser plenamente aplicados no efluente, não permitindo a avaliação da eficiência dos mesmos nesta matriz complexa. Uma forma de contornar esse problema seria coletar o efluente em outro ponto do processo industrial, por exemplo, logo após a etapa de tingimento, onde o teor e diversidade de compostos orgânicos costumam ser menores.

\subsection{Metais suportados em SMO}

\subsection{1. $\mathrm{O}_{3} / \mathrm{pH} 3 / \mathrm{SMO}-\mathrm{Fe}_{2} \mathrm{O}_{3}$}

Os estudos apresentados até o atual momento mostraram resultados bons de mineralização; valendo ressaltar que neste caso todas as espécies foram adicionadas em solução. Portanto, como etapa final deste trabalho, buscou-se avaliar o uso de metais de forma suportada estudando a sua eficiência.

Através dos estudos anteriores, observou-se que a presença de ferro(III) em solução acarretou uma melhora nas taxas de mineralização do azocorante modelo. Uma outra abordagem para avaliar a eficiência da presença deste metal no processo é a sua utilização sobre um suporte; e, neste caso, a eficiência 
depende das propriedades de superfície, as quais estão intimamente relacionadas com o $\mathrm{pH}$. Dentro deste contexto, as SMO se destacam como boas alternativas de suporte, pois possuem, dentre outras características, grande área superficial $\left(740 \mathrm{~m}^{2} \mathrm{~g}^{-1}\right)$.

Na Figura 34, pode-se observar que a presença do ferro incorporado na SMO ocasionou um aumento nas taxas de remoção de COT. Os diferentes procedimentos para a eliminação do solvente durante a síntese (item 3.5.2) permitiram a obtenção de suportes com teores de ferro distintos (A1: SMO com $1,60 \%$ de $\mathrm{Fe}_{2} \mathrm{O}_{3}$ e $\mathrm{A} 2: \mathrm{SMO}$ com $3,67 \%$ de $\mathrm{Fe}_{2} \mathrm{O}_{3}$ ). O material com praticamente o dobro de ferro permitiu um acréscimo de somente $10 \%$ na remoção de COT.

Empregando-se o tratamento com $\mathrm{O}_{3} / \mathrm{pH} 3 / \mathrm{SMO} / \mathrm{Fe}_{2} \mathrm{O}_{3}$ por 30 minutos não se conseguiu estabelecer uma tendência clara sobre o comportamento da mineralização em função do tempo, assim buscou-se estudar este tratamento por mais tempo (120 minutos). Como pode ser observado na Figura 34 , um maior tempo de tratamento promoveu aumento da mineralização em ambos os casos (21 e 34\% em relação à proporção de ferro no catalisador 1,60 e 3,67\% , respectivamente).

Para verificar a contribuição de cada componente do catalisador na eficiência do tratamento, realizaram-se processos separadamente, ou seja, $\mathrm{O}_{3} / \mathrm{pH} 3 / \mathrm{SMO}$ e $\mathrm{O}_{3} / \mathrm{pH}_{3} / \mathrm{Fe}_{2} \mathrm{O}_{3}$. A contribuição de ambos os sistemas, entretanto, foi pouco significativa sobre o teor de mineralização quando comparada com o processo $\mathrm{O}_{3} / \mathrm{pH} 3$. 


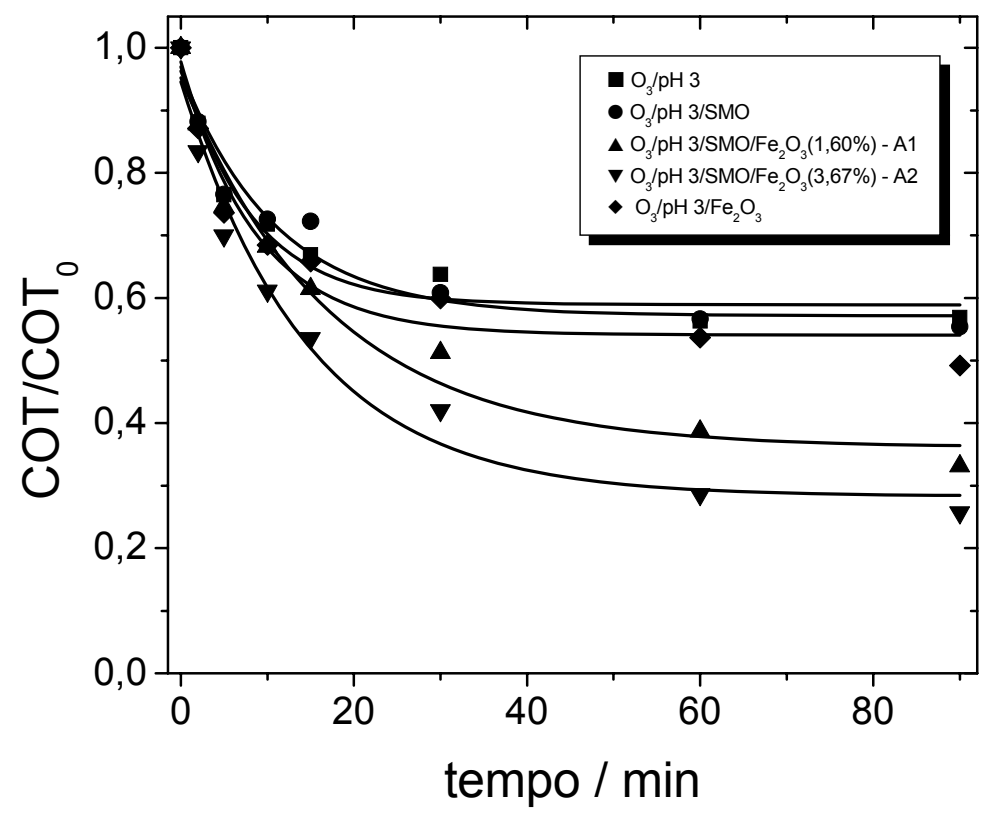

Figura 34. Variação da concentração do carbono orgânico total em função do tempo de ozonização de uma solução do corante Preto Remazol B em diferentes condições de sílica. Condições experimentais: $\mathrm{pH}=3$; [corante $]_{0}=100 \mathrm{mg} \mathrm{L}^{-1}$; vazão de $\mathrm{O}_{2}=54 \mathrm{~L} \mathrm{~h}^{-1}$.

Quando se utilizou o catalisador contendo ambos os materiais, o que se observa é um efeito sinérgico na eficiência do processo quando comparado com $\mathrm{O}_{3} / \mathrm{pH} 3 / \mathrm{SMO}$ e $\mathrm{O}_{3} / \mathrm{pH}_{3} / \mathrm{Fe}_{2} \mathrm{O}_{3}$.

Assim, os melhores resultados são fruto da conjugação das propriedades catalíticas do $\mathrm{Fe}_{2} \mathrm{O}_{3}$ com a área superficial elevada do suporte utilizado, o que justificou a busca por outros sistemas que exibissem propriedades catálisesuperfície similares.

\subsection{2. $\mathrm{O}_{3} / \mathrm{pH} 3 / \mathrm{SMO}-\mathrm{MnO}_{2}$}

Seguindo esta mesma tendência de estudo de metais suportados em SMO, incorporou-se $\mathrm{MnO}_{2}$ através da mesma rota sintética utilizada anteriormente 
(incorporação, item 3.5.3.1).

$\mathrm{Na}$ Figura 35 observa-se o efeito do catalisador à base de $\mathrm{MnO}_{2}$ no teor de mineralização. Os resultados, nesse caso, foram insatisfatórios; a mineralização foi comparável àquela observada para os dois sistemas apresentados como controle anteriormente (a saber, $\mathrm{O}_{3} / \mathrm{pH}_{3}$ e $\mathrm{O}_{3} / \mathrm{pH} 3 / \mathrm{SMO}$ ). Isso sugere que o processo de síntese do catalisador de $\mathrm{MnO}_{2}$ não foi tão eficiente quanto para o $\mathrm{Fe}_{2} \mathrm{O}_{3}$, o que pode se dever às diferenças estruturais dos referidos óxidos que, por sua vez, refletem numa menor disponibilidade do centro metálico para o processo de degradação do substrato (menor disponibilidade de sitos ativos devido a obstruções dos mesoporos do suporte).

Diante disso, buscou-se aprimorar estes resultados empregando uma nova rota sintética para o catalisador (modificação superficial, item 3.5.3.2).

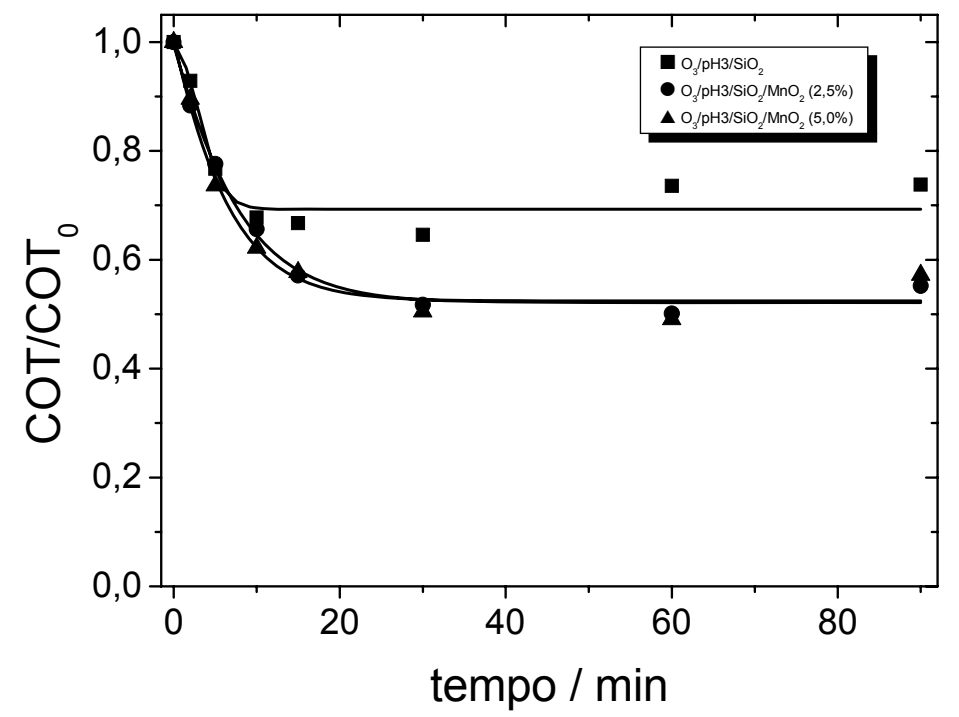

Figura 35. Variação da concentração do carbono orgânico total em função do tempo de ozonização de uma solução do corante Preto Remazol B na presença de manganês nas concentrações de $2,5 \%$ e $5,0 \%$. Condições experimentais: $\mathrm{pH}=3$; [corante] $]_{0}=100 \mathrm{mg} \mathrm{L}^{-1}$; vazão de $\mathrm{O}_{2}=54 \mathrm{~L} \mathrm{~h}^{-1}$. 
Observa-se na Figura 36, que a síntese que leva somente à modificação superficial provocou melhoras apreciáveis comparando-se com os resultados obtidos para as mesmas concentrações usando o outro procedimento.

Analisando a Figura 36, a presença de 2,5\% de manganês na sílica obtido após a modificação superficial apresentou o melhor resultado, não havendo diferença significativa na mineralização quanto a porcentagem do metal foi aumentada. Em 15 minutos tem-se uma mineralização de 68\% levando a uma melhora em torno de $250 \%$ se comparado com a sílica pura. Uma possível hipótese para esta piora é a saturação dos sítios ativos do suporte em função do aumento na concentração de $\mathrm{Mn}$. O uso dos metais suportados se apresentou como uma alternativa eficaz na degradação/mineralização de corantes.

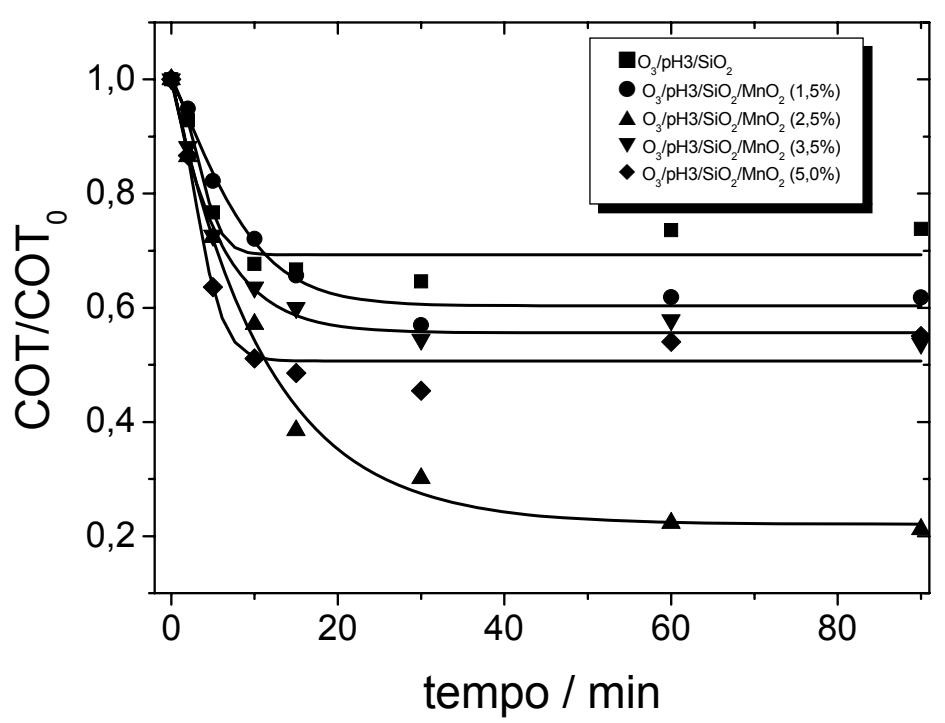

Figura 36. Variação da concentração do carbono orgânico total em função do tempo de ozonização de uma solução do corante Preto Remazol B das diferentes concentrações de manganês (1,5, 2,5, 3,5 e $5,0 \%$ ). Condições experimentais: $\mathrm{pH}=3$; [corante $]_{0}=100 \mathrm{mg} \mathrm{L}^{-1}$; vazão de $\mathrm{O}_{2}=54 \mathrm{~L} \mathrm{~h}^{-1}$. 


\section{CONCLUSÃO}

No decorrer da execução deste trabalho, as etapas de desenvolvimento e montagem do sistema de ozonização foram de extrema importância. Isto proporcionou uma melhor compreensão e controle das etapas envolvidas no processo como, por exemplo, geração e detecção do ozônio.

Dentre os diversos parâmetros estudados, o pH se apresenta como um dos de maior relevância, pois através da sua variação o ozônio pode interagir por diferentes mecanismos. No caso do azocorante modelo em estudo, houve um aumento nas taxas de remoção de COT com a elevação do pH. Isto ocorre devido à interação dos ânions hidroxila com o ozônio, levando à geração de radicais hidroxila.

Como uma alternativa à ozonização em meio básico, a qual é bem estabelecida na literatura, buscaram-se novos processos emergentes que visam o aumento da eficiência do processo de ozonização na mineralização de compostos poluentes. Dentre estes, se enfatizou o uso de peróxido de hidrogênio, íons metálicos em solução e suportados sobre um substrato poroso.

As adições de peróxido de hidrogênio, de íons ferro e manganês ao processo, em geral, ocasionaram um acréscimo nas taxas de mineralização quando comparados com o processo $\mathrm{O}_{3} / \mathrm{pH}$. Cabe ressaltar que há uma dependência direta tanto da concentração de peróxido de hidrogênio quanto da concentração do íon metálico adicionado sobre as taxas de redução do COT. Em todos os casos pode-se estimar um intervalo de concentração ótimo.

Tendo em vista o bom desempenho apresentado pelos íons metálicos em solução, buscou-se uma maneira de utilizá-los sob uma forma suportada visando 
que os mesmos pudessem ser utilizados de forma contínua. Isto minimizaria etapas de recuperação ou perdas destes materiais.

O emprego destes agentes catalisadores suportados sobre SMO proporcionou bons graus de mineralização contribuindo, assim, para o aumento da eficiência do processo. Neste sentido a ozonização catalítica demonstrou ser uma alternativa promissora para degradação/mineralização de corantes.

\subsection{Perspectivas}

Como foi apresentado na discussão, como hipótese de mecanismo no caso do manganês, por exemplo, tem-se a formação de dióxido de manganês, mas isto não está muito bem explorado nos trabalhos correntes. Neste sentido, se devem buscar alternativas para propor os mecanismos envolvidos no processo de ozonização catalítica homogênea como também detectar e quantificar os subprodutos formados e inferir a respeito da sua toxicidade.

Também se destaca a necessidade de explorar o uso de suportes avaliando o efeito de outros tipos de síntese buscando o aumento da área superficial e um aumento da interação do metal com ozônio e como isso um aumento nas taxas de remoção de carbono orgânico total. 


\section{REFERÊNCIAS}

1. Rebouças, A.; Braga, B.; Tundisi, J.; Águas Doces no Brasil, 2a ed., Escrituras Editora: São Paulo, 2002.

2. Branco, S. M.; Água: origem, uso e preservação, ed. Moderna: São Paulo, 1993.

3. Freire, R. S.; Pelegrini R.; Kubota L. T.; Durán N.; Quim. Nova 2000, 23, 504.

4. Pereira, W. S; Freire, R. S.; Quim. Nova 2005, 28, 130.

5. Kunz, A.; Peralta-Zamora, P.; Moraes, S. G.; Duran N.; Quim. Nova 2002, 25, 78.

6. Guaratini, C. C. I.; Zanoni M. V. B.; Quim. Nova 2000, 23, 71.

7. Bitton, G.; Wastewater Microbiology, ed. Willey-Liss: New York, 1994.

8. Hirvonen, A.; Tuhkanen, T.; Kalliokoski, P.; Wat. Sci. Technol. 1996, 33, 67.

9. Paraskeva, P.; Diamadopoulous, E. J.; J. Chem. Tecnhol. Biotechnol. 2006, 81, 1475.

10. Ikehata, K.; EL-Din, M.G.; J. Environ. Eng. Sci. 2006, 5, 81.

11. Pera-Titus, M.; Garcia-Molina, V.; Banos, M.A.; Gimenez, J.; Esplugas, S.; Appl. Catal. B: Environ. 2004, 47, 219.

12. Baird, C.; "Química Ambiental"; ed. Bookman: Porto Alegre, 2002.

13. Kunz, A.; "Tese de Doutorado"; Instituto de Química/UNICAMP, 1999.

14. Gottschalk, C.; Libra, A. J.; Saupe, A.; Ozonation of water and waste water, Wiley-Vch: Weinheim, 2000.

15. Atkins, P. W.; Physical chemistry, 7a ed., Oxford: New York, 2002.

16. Manahan, S. E.; Enviromental Chemistry, 8a ed., CRC Press: Boca Raton, 2005. 
17. Lee, J. D.; Química inorgânica não tão concisa, 2a ed., Editora Edgard Blücher: São Paulo, 2001.

18. McMurry, J.; Química Orgânica, 6a ed., Editora Pioneira Thomson Learning: São Paulo, 2005.

19. Hoigné, J.; Bader, H.; Water Res. 1983, 17, 173.

20. Hoigné, J.; Bader, H.; Water Res. 1983, 17, 185.

21. Hoigné, J.; Bader, H.; Water Res. 1985, 19, 993

22. Dhandapani, B.; Oyama, S. T.; Appl. Catal. B: Environ. 1997, 11, 129.

23. Alebic-Juretic, A.; Cvitas, T.; Klasinc, L.; Chemosphere 2000, 41, 667.

24. Lin, J.; Kawai, A.; Nakajima, T.; Appl. Catal. B: Environ. 2002, 39, 157.

25. Kasprzyk-Hordern, B.; Ziólek, M.; Nawrocki, J.; Appl. Catal. B: Environ. 2003, $46,639$.

26. Mao, H.; Smith, D.; Ozone Sci Eng. 1995, 17, 205.

27. Staehelin, J.; Holgné, J.; Environ. Sci. Technol. 1985, 19, 1206.

28. Legube, B.; Karpel; V. L. N.; Catal. Today 1999, 53, 61.

29. Masten, S.J.; Davies, S.H.R.; Environ. Sci. Technol. 1994, 28, 180.

30. Arslan, I.; Akmehmet Balcioglu, I.; Tuhkanen, T.; Environ. Technol. 1999, 20, 921.

31. Freire, R.S., Kubota, L.T., Durán, N.; Environ. Technol. 2001, 22, 897.

32. Herrmann, J.M.; Catal. Today 1999, 53, 115.

33. Ghaly, M.Y.; Härtel G.; Mayer R.; Haseneder, R.; Afinidad LVII 2000, 490, 424.

34. Kool, H. J.; Hrubec, J.; Ozone Sci. Eng. 1986, 8, 217.

35. Silva, L. M.; Jardim, W. F.; Quim. Nova 2006, 29, 310.

36. Almeida, E.; Assalin, M. R.; Rosa, M. A.; Quim. Nova 2004, 27, 818. 
37. Balcioglu, I. A.; Otker, M.; Chemosphere 2003, 50, 85.

38. Freire, R. S.; Kunz, A.; Durán, N.; Environ. Technol. 2000, 21,717.

39. Moraes, S. G.; Freire, R. S.; Durán, N.; Chemosphere 2000, 40, 369.

40. Freire, R. S.; Kubota, L. T.; Durán, N.; Environ. Technol. 2001, 22, 897.

41. Pines, D. S.; Reckhow D. A.; Environ. Sci. Technol. 2002, 36, 4046.

42. Farré, M. J.; Franch, M. I.; Malato, S.; Ayllón, J. A.; Peral. J.; Doménech, X.; Chemosphere 2005, 58, 1127;

43. Beltrán, F. J.; Rivas, J.; Álvez, P.; Montero-de-Espinosa, R.; Ozone Sci. Eng. 2002, 24, 227.

44. Ni, C. H.; Chen, J. N.; Yang P. Y.; Wat. Sci. Technol. 2002, 47, 77.

45. Hill, G.; J. Am. Chem. Soc. 1948, 70, 1306.

46. Hill, G.; J. Am. Chem. Soc. 1949, 71, 2434.

47. Sauleda, R.; Brillas, E.; Appl. Catal. B: Environ. 2001, 29,135.

48. Piera, E.; Calpe, J. C.; Brillas, E.; Doménech, X.; Peral, J.; Appl. Catal. B: Environ. 2000, 27, 169.

49. Arslan, I.; Balcioglu, I. A.; Tuhkanen, T.; Wat. Sci. Technol. 2000, 42, 13.

50. Beltrán, F. J.; Rivas, F. J.; Montero-de-Espinosa, R.; Ind. Eng. Chem. Res. 2003, 42, 3210.

51. Andreozzi, R.; Caprio, V.; Insola, A.; Marotta, R. T.; Tufano, V.; Wat. Res. 1998, 32, 1492.

52. Andreozzi, R.; Caprio, V.; Insola, A.; Marotta, R. T.; Tufano, V.; Wat. Res. 2001, 35, 109.

53. Ma, J.; Graham, J. D.; Ozone Sci. Eng. 1997, 19, 227.

54. Ma, J.; Graham, J. D.; Wat. Res. 1999, 33, 785. 
55. Rakitskaya, T. L.; Ennan, A. A.; Granatyuk, I. V.; Bandurko, A. Y.; Balavoine, G. G. A.; Geletii, V. Y.; Paina, V. Y; Catal. Today 1999, 53, 715.

56. Einaga, H.; Harada, M.; Futamura, S.; Chem. Phys. Lett. 2005, 408, 377.

57. Beltrán, F. J.; Rivas ,F. J.; Montero-de-Espinosa, R.; Ind. Eng. Chem. Res. 2003, 42, 3218.

58. Nawrocki, J.; Rigney, M. P.; McCormick, A.; Carr, P. W.; J. Chromatogr. A 1993, 657, 229.

59. Bulanin, K. M.; Lavalley, J. C.; Tsyganenko, A. A.; J. Phys. Chem. 1994, 99, 10294.

60. Ni, C. H.; Chen, J. N.; Water Sci. Technol. 2001, 43, 213.

61. Legrini, O.; Oliveros, E.; Braun, A. M.; Chem. Rev. 1993, 93, 671.

62. Kresge, C. T.; Leonowicz, M. E.; Roth, W. J.; Vartuli, J. C.; Beck, J. S.; Nature, 1992, 359, 710.

63. Beck, J. S.; Vartuli, J. C.; Roth, W. J.; Leonowicz, M. E.; Kresge, C. T.; Schmitt, K. D.; Chu, C. T. W.; Olson, D. H.; Sheppard, E. W.; McCullen, S. B.; Higgins, J. B.; Schlenker, J. L.; J. Am. Chem. Soc. 1992, 114, 10834.

64. Selvam, P.; Bhatia, S. K.; Sonwane, C. G.; Ind. Eng. Chem. Res. 2001, 40, 3237.

65. Ciesla, U.; Schüth, F.; Microporous and Mesoporous Mater. 1999, 27, 131.

66. Linssen, T.; Cassiers, K.; Cool, P.; Vansant, E. F.; Adv. Colloid Interface Sci. 2003, 103, 121.

67. Da Silva, L. C. C.; Martins, T. S.; Filho, M. S.; Teotonio, E. E. S.; Isolani, P. C.; Brito, H. F.; Tabacniks, M. H.; Fantini, M. C. A.; Matos, J. R.; Microporous and Mesoporous Mater. 2006, 92, 94. 
68. Gracia R.; Cortés S.; Sarasa, J.; Ornad, P.; Ovelleiro, J. L.; Ozone Sci. Eng. $2000,22,461$.

69. Gracia, R.; Cortés, S.; Sarasa, J.; Ormad, P.; Ovelleiro, J. L.; Ozone Sci. Eng. 2000, 22, 185.

70. Gracia, R.; Cortés, S.; Sarasa, J.; Ormad, P.; Ovelleiro, J. L.; Water. Res. 2000, 34, 1525.

71. Cooper, C.; Burch, R.; Water Res. 1999, 33, 3695.

72. Al-Hayek, N.; Legube, B.; Dore, M.; Environ. Technol. Lett. 1989, 10, 415.

73. Ping, T. S.; Hua, L. W.; Qing, Z. J.; Nan, C. C.; Ozone Sci. Eng. 2002, 24, 117.

74. Villaseñor, J.; Reyes, P.; Pecchi, G.; Catal. Today 2002, 76, 121.

75. Lin, J.; Nakajima, T.; Jomoto, T.; Hiraiwa, K.; Ozone Sci. Eng. 2000, 22, 241.

76. Kunz, A.; Freire, R.; Rohwedder, J.; Duran, N.; Quim. Nova 1999, 23, 425.

77. Standard Methods for the Examination of Water and Wastwater, $20^{\mathrm{a}}$ ed., CDIS: CD-ROM, 1998.

78. Langlais, B.; Reckhow, D. A.; Brink, D. R.; Ozone in Water Treatment; Lewis Publishers, 1991.

79. Alvares, A. B. C.; Diaper, C.; Parsons, S. A.; Environ. Technol. 2001, 22, 409.

80. Wu, J.; Eiteman, M. A.; Lau, S. E; J. Environ. Eng. 1998, 124, 272.

81. Shu, H.; Huang, C.; Chemosphere 1995, 31, 3813.

82. Lin, S. H.; Liu, W. Y.; Environ. Technol 1994, 15, 299.

83. Liakou, S; Pavlou, S; Lyberatos, G; Water Sci. Technol. 1997, 35, 279.

84. Gogate, P. R.; Pandit, A. B.; Adv. Environ. Res. 2004, 8, 501.

85. Balcioglu, I. A.; Arslan, I.; Water Sci. Technol. 2001, 43, 228.

86. Brunet, R.; Bourbigot, M. M.; Dore, M.; Ozone Sci. Eng. 1984, 6, 163. 
87. Araújo, F. V. F. A.; Yokoyama, I.; Quim. Nova 2006, 29, 11.

88. Verma, P.; Baldrian, P.; Nerud, F.; Chemosphere 2002, 50, 975.

89. Meriç, S.; Selcuk, H.; Gallo, M.; Belgiorno, V.; Desalination 2005, 173, 239.

90. Canton, C.; Esplugas, S.; Casado, J.; Appl. Catal. B: Environ. 2003, 43, 139. 


\section{CURRICULUM VITAE}

\section{AMIRA MAHMOUD}

Data de nascimento: 09/04/1981

Naturalidade: São Paulo/SP

E-mail: mahmoud.amira@gmail.com

\subsection{Histórico Educacional}

$2004-2006$

Universidade de São Paulo - USP

Mestrado em Química Analítica / Ambiental

$1999-2005$

Universidade de São Paulo - USP

Bacharelado com Atribuições Tecnológicas

$1999-2003$

Universidade de São Paulo - USP

Licenciatura em Química

$1999-2002$

Universidade de São Paulo - USP

Bacharelado em Química

\subsection{Cursos}

Workshop "Fotoquímica aplicada" - 2005

$28^{a}$ Reunião Anual da Sociedade Brasileira de Química, Poços de Caldas, Minas 2005.

\subsection{Publicação em Revista Científica}

Mahmoud, A., Freire, R. F.; "MÉTODOS EMERGENTES PARA AUMENTAR A EFICIÊNCIA DO OZÔNIO NO TRATAMENTO DE ÁGUAS CONTAMINADAS", Química Nova 2006, no prelo.

\subsection{Participação em Congresso}

Mahmoud, A., Freire, R. F., "OZONIZAÇÃO CATALÍTICA HETEROGÊNEA DO AZOCORANTE REMAZOL PRETO B USANDO $\mathrm{Fe}_{2} \mathrm{O}_{3} / \mathrm{SiO}_{2}$ ", $29^{a}$ Reunião Anual da Sociedade Brasileira de Química, Águas de Lindóia, São Paulo 2006. 
Nascimento, A. A. I., Mahmoud, A., Freire, R. F., "INFLUÊNCIA DA VARIAÇÃO DO PH DE ÍONS METÁLICOS NA OZONIZAÇÃO DO EDTA", $29^{a}$ Reunião Anual da Sociedade Brasileira de Química, Águas de Lindóia, São Paulo 2006.

Mahmoud, A., Freire, R. F., "OZONIZAÇÃO CATALÍTICA HOMOGÊNEA DO AZO CORANTE REMAZOL PRETO B", III Encontro Nacional de Química Ambiental, Cabo Frio, Rio de Janeiro 2006.

Mahmoud, A., Freire, R. F., "EMPREGO DO PROCESSO DE OZONIZAÇÃO NA MINERALIZAÇÃO DE COMPOSTOS FENÓLICOS”, $28^{\mathrm{a}}$ Reunião Anual da Sociedade Brasileira de Química, Poços de Caldas, Minas 2005.

Mahmoud, A., Freire, R. F., "DEGRADAÇÃO DO AZOCORANTE PRETO REMAZOL B EMPREGANDO-SE OZÔNIO", $28^{a}$ Reunião Anual da Sociedade Brasileira de Química, Poços de Caldas, Minas 2005. 